\title{
Essays on Foreign Direct Investment, International Trade, and Inequality
}

by

\author{
Nam Minh Ngo \\ A thesis submitted to Victoria University of Wellington \\ in fulfilment of the requirements for the degree of \\ Doctor of Philosophy in Economics
}

Victoria University of Wellington

2020 


\begin{abstract}
This thesis consists of three empirical essays on the impact on inequality of Foreign Direct Investment (FDI), international trade, and technological progress that comes with them. The first essay examines whether FDI contributes towards income convergence of the host country, drawing evidence from provincial data in Vietnam. Using the spatial econometrics approach and an exogenous set of distance-based weights to characterize spatial dependences, we identify the substantial role of both spatial interactions and FDI spillovers in bringing provinces closer together in terms of income level. We show that high-tech FDI and industry FDI agglomerations contribute significantly more towards the convergence process than low-tech FDI and agglomerations formed by FDI firms coming from the same country. A similar pattern also emerges when we consider consumption convergence. The second essay studies the impact of local labour demand shocks from FDI firms on wage distribution, using microdata from the Vietnam Household Labour Force Survey. We use Bartik shift-share instrument based on the interaction between predetermined local employment structure and time-varying nationwide employment to deal with the endogeneity between local wage level and multinational firms' locational decisions. Overall, we find that surges in foreign hiring increase average local wage, but the benefits are considerably higher for workers who work in lower-skilled occupations or have lower educational attainments. Given the prevailing skill and education wage premium, this heterogeneous effect provides evidence that the presence of FDI firms can reduce wage inequality. The third essay analyzes the association between income inequality, dependence on the manufacturing sector, and the availability of vocational education as an alternative track to general tertiary education. We find that in countries where tertiary and vocational are the two main available pathways for students to pursue, as economic recovery, trade, and automation increases the value-added of the manufacturing sector but decreases the number of manufacturing jobs, improving access to vocational education is associated with a larger decline in inequality compared to tertiary education. Therefore, in the long run, limited public resources should be directed towards vocational education in order to smooth out adjustment to trade and skilled-biased technological change. A case study comparing the United States and Germany in terms of their recovery paths from the Global Financial Crisis provide further evidence for our claims.
\end{abstract}




\section{Acknowledgement}

My $\mathrm{PhD}$ journey is a long but interesting one, mainly thanks to the people that I have the opportunities to work and interact with along the way. My sincerest gratitude goes to my supervisor Prof. Yothin Jinjarak for continuously supporting me and providing invaluable guidance for my research, for encouraging me to explore career opportunities, and for being super relaxed when I wanted to try different things. I learned a lot from him, both academically and as a person. For this, I consider myself extremely lucky. I am also grateful to my secondary supervisor, Dr. Luke Chu, for always available to help. His immense knowledge in econometrics and empirical research has been invaluable throughout my thesis, especially the third chapter. I also wish to express my gratitude to Victoria University of Wellington for funding me through the Victoria Doctoral Scholarship.

Over the last three years, I have also had the opportunity to work in different organizations. I am extremely grateful to my managers at Statistics New Zealand, Alan Bentley and Jasmine Ludwig, for being extremely accommodating while I was working during the final stages of my PhD. I extend great thanks to Alec Kourloukov and Andrew Binning for mentoring me during my internships at the Asian Development Bank and The New Zealand Treasury.

I am grateful to many others who contribute to my thesis. I thank all my PhD colleagues at the School of Economics and Finance for their ideas and discussions along the way. Special thanks also go to the Vietnam Ministry of Planning and Investment for sharing data and valuable knowledge on FDI and Labour Force Survey. I am also thankful for all participants and discussants at several conferences that I participated in, for many great comments and suggestions.

And most importantly, I wish to thank my family and relatives back home in Vietnam, especially my mum and dad, for their continuous and much-needed emotional support. I cannot thank my wife, Trang, enough for moving to New Zealand with me so that I can pursue my $\mathrm{PhD}$, and for always being there for me through a lot of ups and downs throughout my research journey. 


\section{Table of Contents}

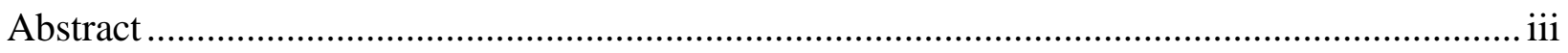

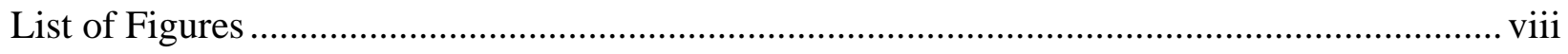

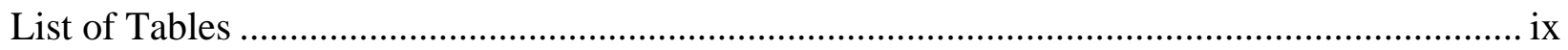

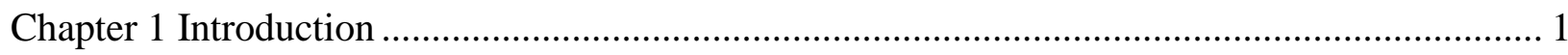

Chapter 2 FDI agglomerations and income convergence: Evidence from Vietnamese provinces 4

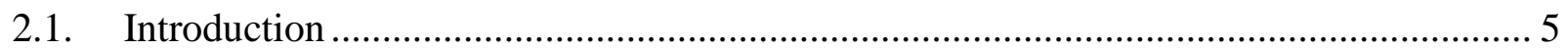

2.2. Theoretical frameworks and related studies ………….................................................. 7

2.2.1. Income convergence and spatial dependences ........................................................ 7

2.2.2. FDI agglomeration and spillover effects ............................................................ 9

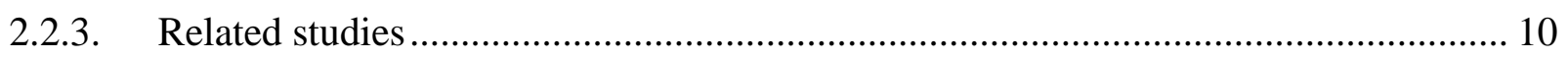

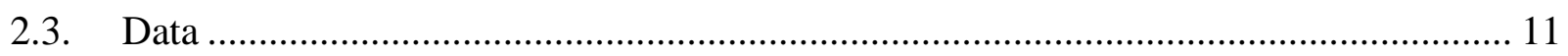

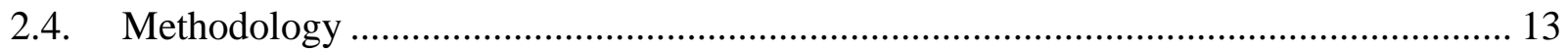

2.4.1. Spatial weighting matrix ................................................................................... 13

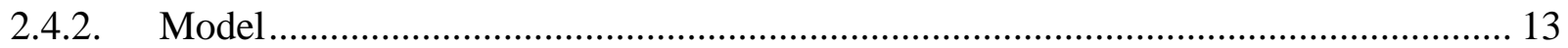

2.4.2.1. FDI technology levels and income convergence ................................................. 14

2.4.2.2. FDI agglomerations and income convergence................................................. 16

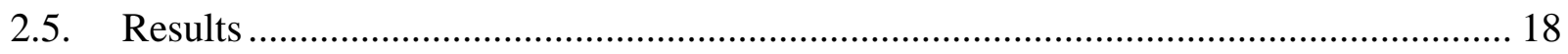

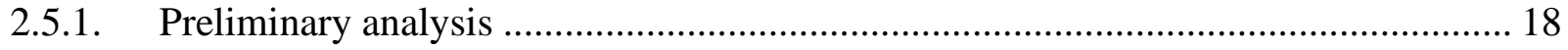

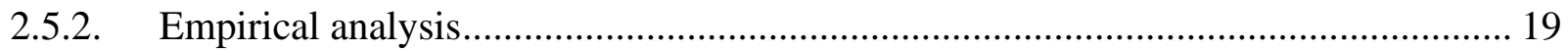

2.5.2.1. FDI technology levels and income convergence ................................................. 19

2.5.2.2. FDI agglomerations and income convergence.................................................. 22

2.5.2.3. Prospective FDI and income convergence ........................................................ 23

2.5.2.4. FDI and consumption convergence …………............................................ 24

2.6. Robustness checks ............................................................................................. 25

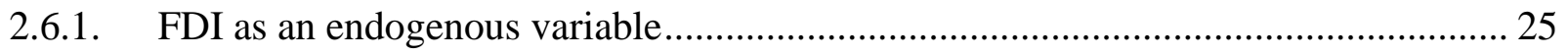

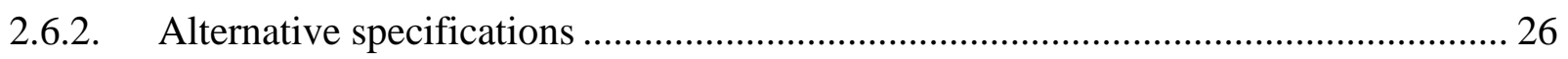

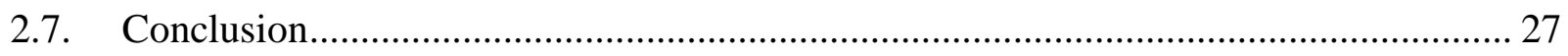

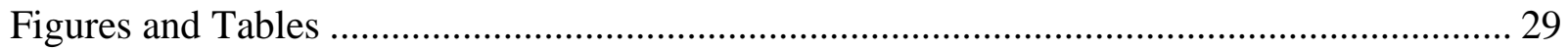

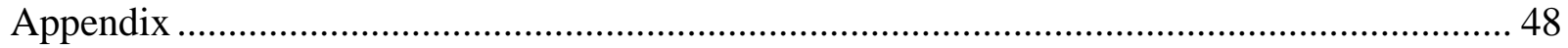


Chapter 3 FDI inflows and wage inequality: Evidence from Vietnamese labour market post-

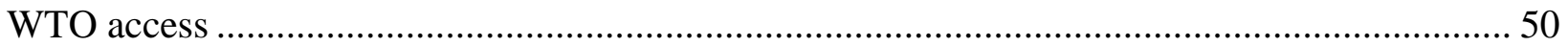

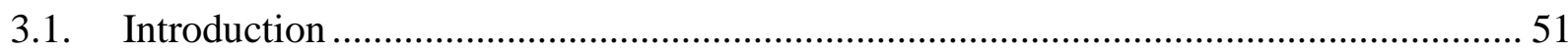

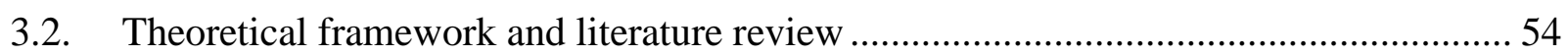

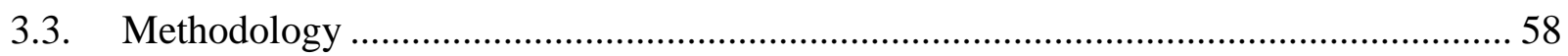

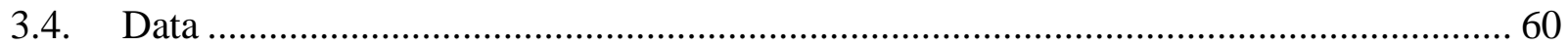

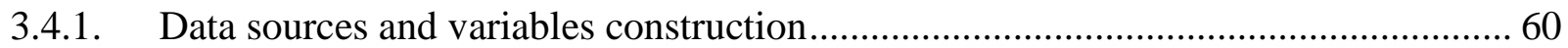

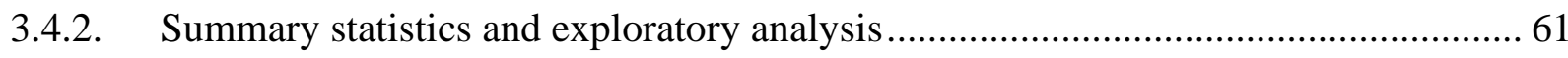

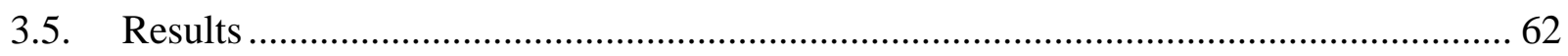

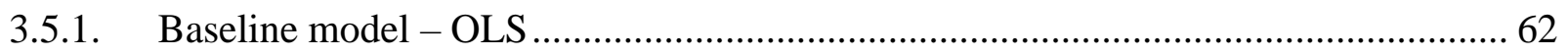

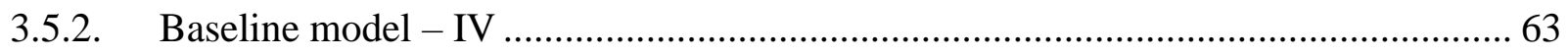

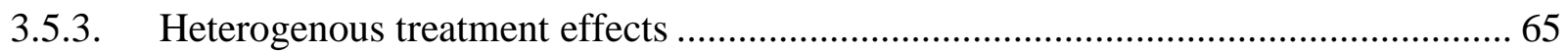

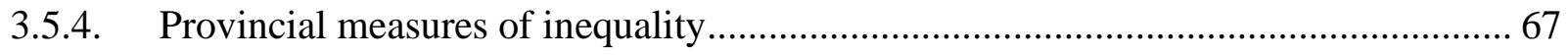

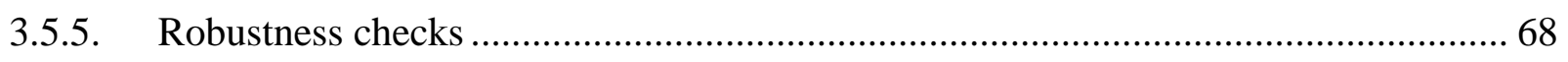

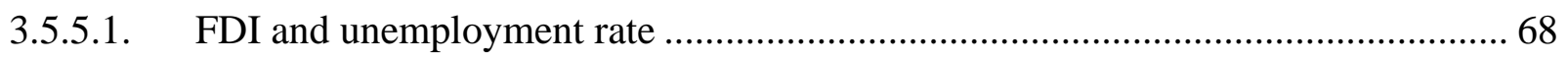

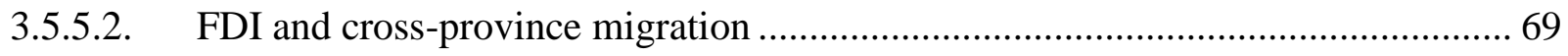

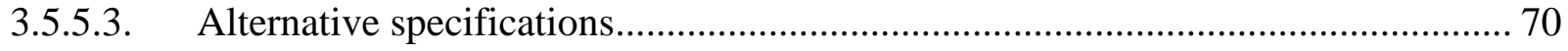

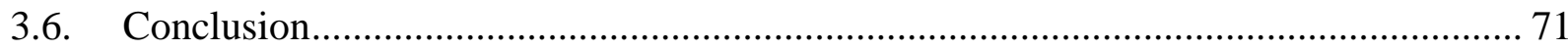

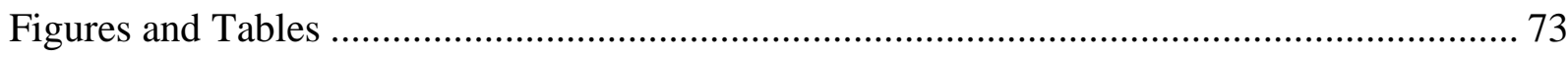

Chapter 4 Vocational Education, Manufacturing Competitiveness, and Income Distribution:

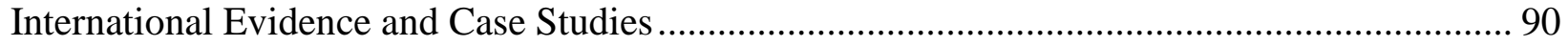

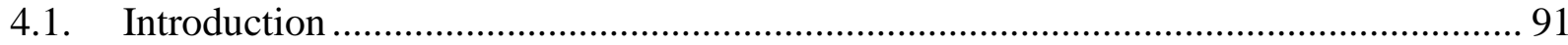

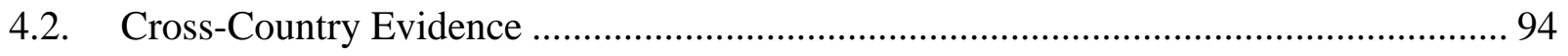

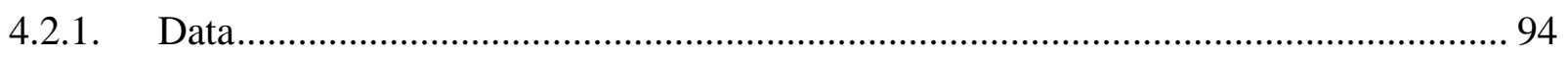

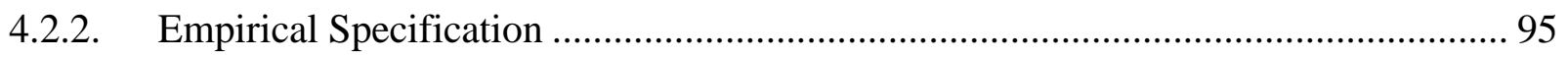

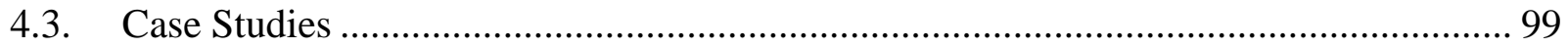

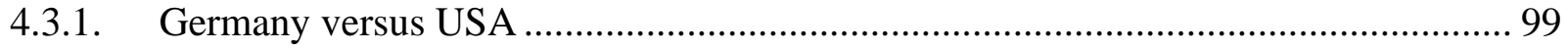

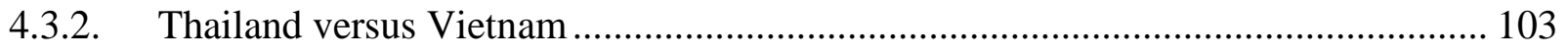

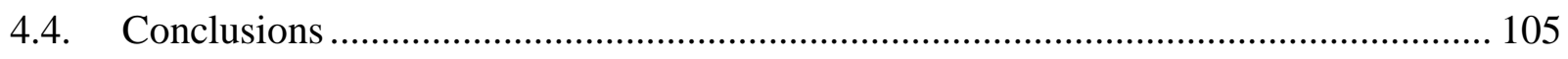

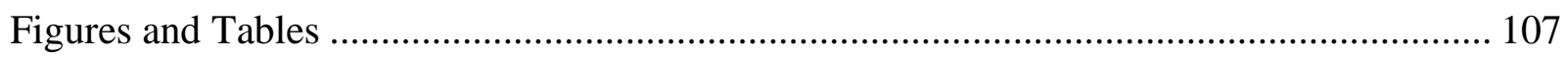

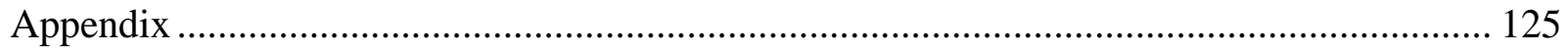

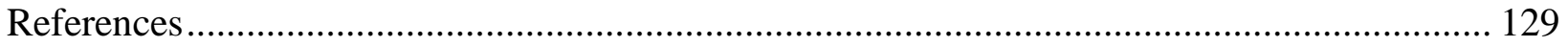




\section{List of Figures}

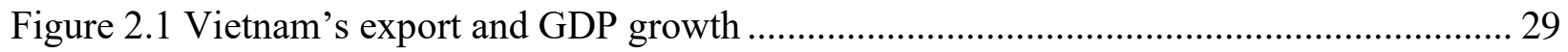

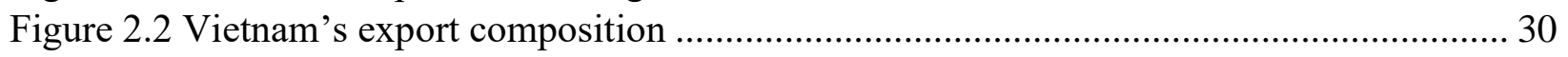

Figure 2.3 Vietnam greenfield FDI capital 2003-2017 .................................................. 31

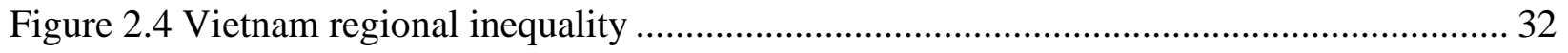

Figure 2.5 Gross and net FDI inflow - national level.................................................... 33

Figure 2.6 Dispersion and spatial dependences among provincial GDP per capita ................... 34

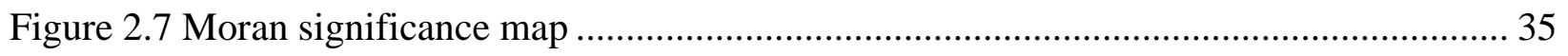

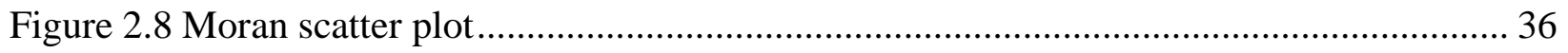

Figure 2.9 Retail trade of goods and services and Private consumption ................................. 42

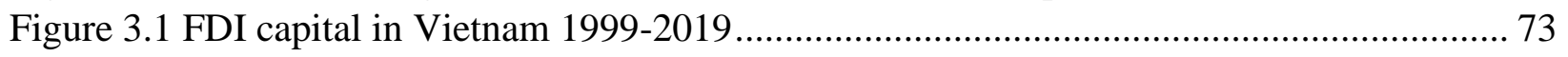

Figure 3.2 FDI's contribution in exports value (\%) - 1995-2015 ......................................... 74

Figure 3.3 FDI jobs distribution by province - average 2010-2015 ..................................... 76

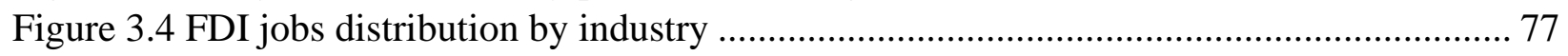

Figure 3.5 National wage Gini coefficient and number FDI jobs......................................... 78

Figure 3.6 Provincial wage Gini coefficients and share of FDI jobs .................................... 79

Figure 3.7 Economic significance of FDI employment .................................................... 82

Figure 3.8 Skill structure of domestic and foreign firms ............................................... 84

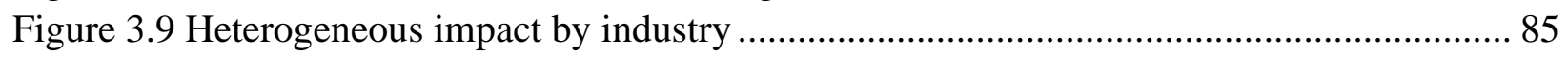

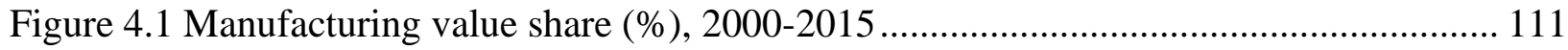

Figure 4.2 Manufacturing employment share (\%), 1970-2012 .......................................... 112

Figure 4.3 Marginal effects of vocational share on predicted inequality ................................. 114

Figure 4.4 Manufacturing (\% of value-added in GDP) ....................................................... 118

Figure 4.5 Indexed Unit Labour Costs in the Manufacturing Sector, 1992-2016 ................... 119

Figure 4.6 Structure of Educational System in Thailand (upper) and Vietnam (lower)............ 121

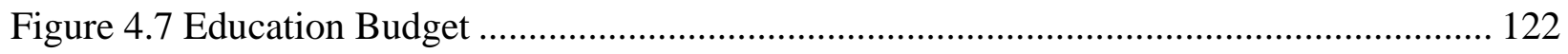

Figure 4.8 Manufacturing Competitiveness.................................................................. 123

Figure 4.9 Distribution of Income of Thailand (upper) and Vietnam (lower)......................... 124 


\section{List of Tables}

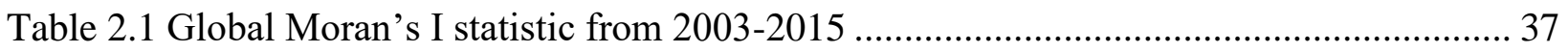

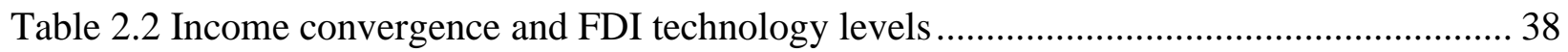

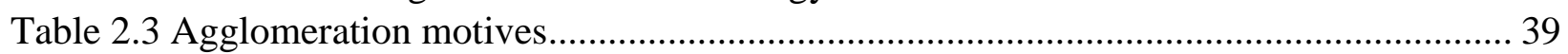

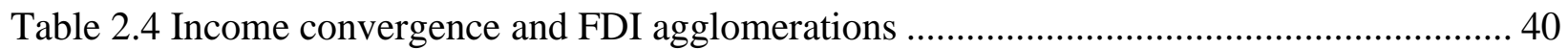

Table 2.5 Current and Prospective FDI and income convergence............................................... 41

Table 2.6 Consumption convergence - FDI technology levels ................................................... 43

Table 2.7 Consumption convergence - FDI agglomerations...................................................... 44

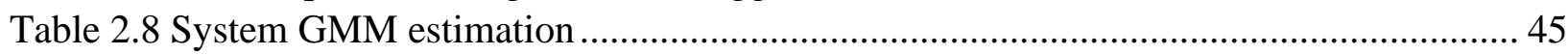

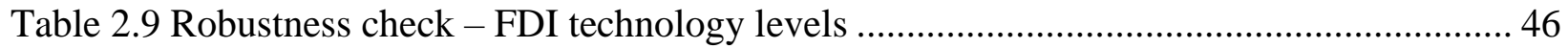

Table 2.10 Robustness check - FDI agglomerations............................................................... 47

Table 3.1 Summary statistics - Wage workers …….............................................................. 75

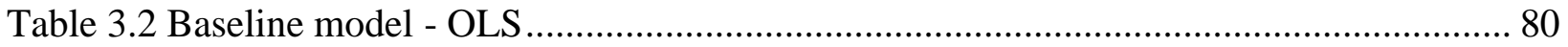

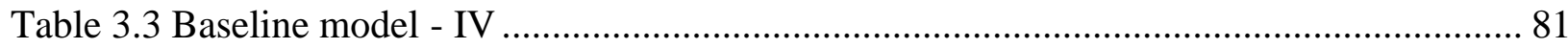

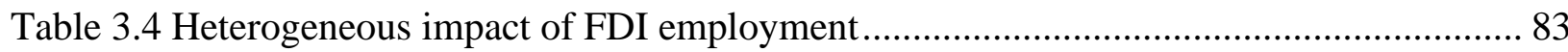

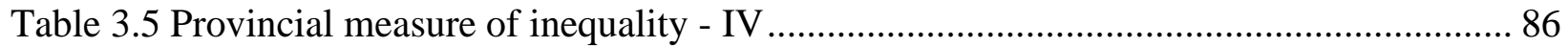

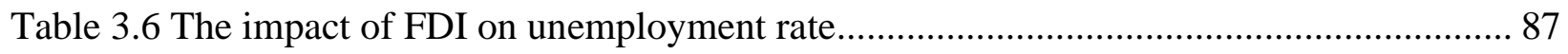

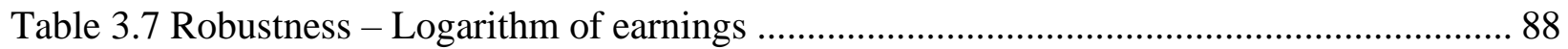

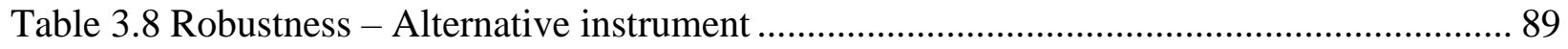

Table 4.1 Country list and summary statistics - Baseline sample ......................................... 107

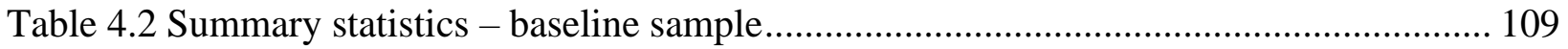

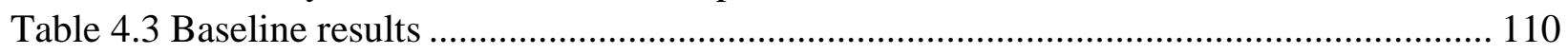

Table 4.4 Baseline results - Manufacturing value share and manufacturing employment share 113

Table 4.5 Baseline results - Continuing vocational training measures ......................................... 115

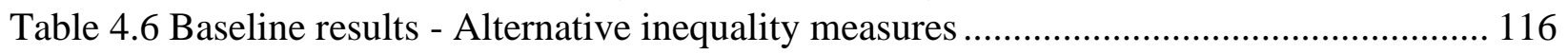

Table 4.7 Alternative inequality measures - Extended sample ............................................... 117

Table 4.8 Education: Germany versus the USA (\% of the population - average 2011-2015) ... 120 


\section{Chapter 1 Introduction}

Foreign direct investment and international trade are widely considered as key growth drivers as they provide the host country with modern technologies, knowledge transfer, and intensive financial capital needed to accumulate income and wealth, and eventually improve living standards. Previous studies have found that the presence of multinational firms and the increase in export opportunities are generally associated with higher wage level, positive productivity spillover, and incorporation into the global supply chain (Lipsey, 2004). However, globalization in general and this type of FDI and export-led model tend to create winners and losers. This thesis consists of three papers with the common theme of identifying and quantifying the impacts of FDI and trade on income and wage inequality. Empirical questions answered in this thesis will provide both qualitative and quantitative evidence for policymakers in their attempts to smooth out adjustments to globalization and ensure inclusive growth. While chapters 2 and 3 focus on FDI in Vietnam as a case study, chapter 4 focuses on both trade and automation from a cross-country perspective.

Chapter 2 is titled "FDI agglomerations and income convergence: Evidence from Vietnamese provinces". In this chapter, we study the association between income convergence, regional disparities, and foreign direct investment in Vietnam from 2003-2015, when the country rapidly and substantially opened to foreign trade and investment. The empirical strategy is built upon theoretical frameworks of beta and sigma convergence (Baumol, 1986; Barro et al, 1991), spatial dependence (Anselin and Rey, 1991), new economic geography (Krugman, 1991; Venables, 2005), and FDI agglomerations (Tan and Meyer, 2011). Provincial income is measured using GDP data from official statistics while FDI capital is measured using deal-level announcement data from fDi Markets, Financial Times. Three empirical questions are considered: (i) What is the role of spatial interactions among provinces in bringing them closer together in terms of income levels? (ii) Does FDI capital in one province spread out the benefits to surrounding provinces and if yes, by how much? (iii) Does type of FDI capital matter in their contributions towards provincial income convergence? Using spatial econometrics approach and an exogenous set of distance-based weights to characterize dependences among provinces, we provide strong supporting evidence of 
income convergences among Vietnamese provinces and the substantial roles of both spatial interactions and FDI spillover effects. We also find that high-tech FDI and industry FDI agglomerations contribute significantly more towards the process than low-tech FDI and agglomerations formed by country of origin. Using retail trade in goods and services statistics as a proxy for consumption, we argue that the same pattern, albeit smaller in magnitude, emerges when considering consumption convergence. This chapter leads to several interesting policy implications. Firstly, local authorities in Vietnam or other similar developing countries should be highly selective in attracting FDI projects. Secondly, they should focus on creating industry FDI agglomerations by allocating sufficient resources to key infrastructure such as industrial parks or processing zones. Thirdly, the central government should play a key role in enhancing the flow of goods and workers among provinces through improving overall infrastructure quality and reforming the household registration system.

Chapter 3 is titled "FDI inflows and wage inequality: Evidence from Vietnamese labour market post-WTO access". In this chapter, we analyze the impact of labour demand shocks from multinational firms on average local wage level and wage inequality using the Vietnam Household Labour Force Survey data from 2010-2015, right after the country became an official member of the World Trade Organization and went through a major revision of its Investment Law. Our arguments are developed based on two main theoretical models regarding FDI firms' offshoring activities (Feenstra and Hanson, 1996; Zhu and Trefler, 2005) and skill mix (McLaren and Yoo, 2017). Our identification strategy relies on the variation of foreign hiring over time in 63 Vietnamese provinces and a rich set of demographics and job-related characteristics. We deal with the potential endogeneity between local average wage and FDI firms' locational decision by constructing a Bartik's (1991) shift-share instrument based on the interaction between provincial industry composition before WTO access and nation-wide FDI employment. Overall, we show that FDI contributes towards raising local wage level, but the magnitude of impact varies among different groups of workers. The benefits are considerably higher for workers who work in lowerskilled occupations or have lower educational attainments. Given the prevailing skill and education wage premium, increasing FDI presence thus can reduce wage inequality. In terms of the spillover effects by industry, we find that workers who work in professional, administrative, IT, and financial are those who reap the most benefits from surges in foreign hiring. Due to the differences 
in the degree of FDI presence between provinces, we argue that our evidence on the dual benefits of increasing the overall wage rate and reducing wage inequality are being driven by only a limited number of provinces. In the future, it is important for policymakers in Vietnam to ensure that FDI jobs are distributed more evenly across the country through continuously enhancing the investment climate and human capital endowment of poorer provinces. In addition, strategic and adequate investment in infrastructure to improve the connection between provinces and between provinces and international connection hubs should also be given a high priority in the policy agenda.

Chapter 4 is titled "Vocational Education, Manufacturing, and Income Distribution: International Evidence and Case Studies". An earlier version of this chapter is published in Open Economies Review Journal ${ }^{1}$. Using cross-country data, we study the association between income inequality, the role of the manufacturing sector in national income, and the availability of vocational education as an alternative track to general tertiary education. Specifically, we examine whether governments should direct limited resources towards tertiary or vocational education to better deal with challenges facing the working poor including declining low income and increasing inequality, if tertiary and vocational are the two main pathways that students can pursue. Our results show that when the manufacturing sector increases its relative share in GDP, but manufacturing jobs disappear due to economic recovery from recessions, automation, and international trade, incremental improvement in vocational education's access for students is associated with a significantly larger decline in inequality compared to tertiary education. Therefore, in the long term, well-resourced and well-targeted vocational training appears to be a better complementary policy for smooth adjustment to trade and skill-biased technological change. We also provide several case studies. Firstly, comparing the US to Germany suggests that pushing more students to colleges may no longer be the most efficient way to deal with the challenges caused by the decline in manufacturing employment. We also note that track records of allocated budget to vocational training, as shown in the case of Vietnam in comparison to Thailand, as well as government subsidies for retraining and upskilling of workers throughout their careers in Singapore, are potential explanations for their relative competitiveness.

\footnotetext{
${ }^{1}$ Aizenmann et al (2018)
} 


\title{
Chapter 2 FDI agglomerations and income convergence: Evidence from Vietnamese provinces
}

\begin{abstract}
This chapter estimates the association between income convergence, regional disparity, and foreign direct investment based on provincial data from Vietnam over two decades. It addresses the issue of growth-interdependent effects from FDI by using exogenous spatial weights among connecting provinces. On the one hand, our findings show both direct and indirect contributions to income convergence from greenfield investment projects, particularly the high-tech FDI and industry FDI agglomerations. On the other hand, low-tech FDI and country of origin agglomerations may even slow down the catching-up process by crowding out domestic enterprises. Therefore, developing countries should attract FDI selectively as well as devote sufficient resources to improving the connections among provinces in order to gain maximum benefit from the convergence process ${ }^{2}$.
\end{abstract}

\footnotetext{
${ }^{2}$ We are grateful to Toshihiro Okubo and the participants at the 2017 Asian Development Bank Institute (ADBI) Conference on Making Trade Inclusive: How to Manage Trade Adjustment in Tokyo for helpful comments. We would like to thank Ilkin Huseynov for his help with the data on FDI projects.
} 


\subsection{Introduction}

Host countries generally consider foreign direct investment (FDI) as good for productivity and economic growth. Generally, the reasoning is that FDI provides countries with technological transfer, as well as human, physical, and financial capital necessary for competition in the global markets and improvement of living standards. The presence of foreign firms is associated with higher average level of wages, positive productivity spillovers, larger scale and more capital intensity of production, incorporation into the global supply chains, and the introduction of new industries (Lipsey, 2004). Yet globalization, and FDI that come with it, tends to create winners and losers. Income distribution within the developing countries and its association with FDI is the focus of this paper.

Against the backdrop of recent adjustments in global trade, we study regional income convergence using a case study based on provincial-level data from Vietnam. Since implementing the major economic reform in 1986 and joining WTO in 2007, Vietnam has achieved rapid yet stable growth rates thanks to a consistently strong export performance (Figure 2.1). More specifically, the growing dependences on manufacturing and FDI firms are two typical features that characterize Vietnam's export-led growth model (Figure 2.2). In fact, only after the inflows of foreign direct investment since the 1980s that the integration into the global supply chains has made Vietnam into one of the most dynamic manufacturing hubs in Asia (Deloitte, 2016). Particularly, for the past fifteen years, FDI firms have brought over USD 200 billion in capital and helped create nearly 1 million new jobs for Vietnam (Figure 2.3).

Despite the solid growth paths and a significant overall contribution from trade and FDI, a question remains for Vietnam whether the benefits have spread throughout its provinces. Figure 2.4 shows that although regional differences are noticeable, there is evidence of convergence among Vietnamese provinces. Specifically, the Red River Delta, South Central Coast, Southeast or Mekong River Delta regions made up the third and fourth quartile (higher-income groups) of provincial GDP per capita distribution in 2003, while the Northwest, Northeast, North Central Coast, and Central Highlands regions belong to the first and second quartile (lower-income groups). For the past fifteen years, the latter group has managed to grow with a rate exceeding the national level, while the former group has been relatively stagnated. If this trend persists, the poorer 
provinces should be able to catch-up in the near future. Intriguingly, apart from the North Central Coast, the rest of Vietnam has attracted very limited greenfield FDI projects. In fact, for the past decade, FDI projects in Vietnam are mainly destined for larger and higher-income provinces such as Hanoi, Da Nang, Ho Chi Minh City, and their surroundings (whose growth rates have been all decelerating). There is a possibility that this income convergence of poorer provinces with limited FDI is a result of spillovers from neighboring richer provinces, apart from the diminishing marginal returns on investments. Moreover, given these observations, it is important to study not only the location and volume of FDI, but also their types, embedded technology levels, and agglomeration motives across the regions. ${ }^{3}$

This paper contributes to the literature by studying the association between income convergence, regional disparity, and foreign direct investment based on provincial data from Vietnam over two decades. Our first empirical question is: do spatial interactions among provinces help bringing them closer together in terms of income levels? If this is the case, FDI - as a potential positive determinant of provincial GDP per capita - can indirectly contribute to the convergence process. Our second question is: does FDI capital in one province spread out the benefits to the surrounding provinces? In fact, as FDI in Vietnam mostly agglomerates in high-income provinces, these spatial spillover effects generate the most viable mechanism in which FDI can directly accelerate the convergence of income among provinces. Our third question is: do different types of FDI contribute differently towards the convergence process? We test this potential heterogeneity by dividing FDI projects in terms of their technology levels, namely high-tech and low-tech; as well as their motives of agglomeration, namely industry/activity and country of origin. In doing so, we aim to provide some useful recommendations for local and national authorities in order to optimize their FDI attraction strategies.

Vietnam offers a relevant and ideal setting for our analysis. With their openness to international trade and investment, multinational firms have invested in a wide range of products and sectors against the backdrop of significant urban-rural division. We address the issue of growthinterdependent effects from FDI by using exogenous spatial weights among connecting provinces. By identifying the existence of spatial spillover effects, we produce strong evidence on the role of

\footnotetext{
${ }^{3}$ Details on the classification method can be found in the Appendix
} 
green-field investment projects in accelerating the provincial income convergence process, particularly the high-tech FDI and industry/activity agglomerations.

The rest of this paper is organized as follows. Section 2.2 overviews the theoretical framework and related studies. Section 2.3 provides data and econometric models. Section 2.4 reports the estimation. Section 2.5 discusses the empirical results. Section 2.6 provides some robustness checks. Section 2.7 concludes.

\subsection{Theoretical frameworks and related studies}

\subsubsection{Income convergence and spatial dependences}

Income convergence, which has been the focal point of growth literature since the pioneering paper of Baumol (1986), exists in two main forms. First of all, the so-called sigma-convergence concerns about the cross-sectional variation of GDP per capita among countries, regions, or provinces and how it evolves ${ }^{4}$. Secondly, beta-convergence focuses on the phenomenon in which poorer provinces are able to grow faster and potentially close the gap in income levels with the richer ones. Although two concepts are closely related, beta-convergence cannot guarantee sigmaconvergence and inequality reduction due to the possibility of random shocks to the process over time (Quah, 1993). Therefore, in order to use the convergence concepts to infer about the inequality dynamics among countries or provinces, it is important to examine both sigma and betaconvergence simultaneously (Rey and Montouri, 1999).

To identify beta-convergence, Islam (2003) suggest a simple econometrics specification using panel set-up, which is adapted from the neoclassical Solow-Swan (1956)'s theoretical growth model with Cobb-Douglas production function and constant elasticity of substitution preferences:

$$
\ln \left(\mathrm{Y}_{\mathrm{i}, \mathrm{t}}\right)-\ln \left(\mathrm{Y}_{\mathrm{i}, \mathrm{t}-1}\right)=\alpha_{\mathrm{i}}+\mu_{t}+\beta \ln \left(\mathrm{Y}_{\mathrm{i}, \mathrm{t}-1}\right)+\delta_{k} X_{i k t}+\varepsilon_{\mathrm{it}}
$$

or equivalently,

\footnotetext{
${ }^{4}$ Coefficient of variation, standard deviation, Gini coefficient or Theil index can all be used to illustrate this concept. Among them, coefficient of variation appears to be the most suitable since it accounts for the common increasing trend of average real GDP per capita
} 


$$
\ln \left(\mathrm{Y}_{\mathrm{i}, \mathrm{t}}\right)=\alpha_{\mathrm{i}}+\mu_{t}+(1+\beta) \ln \left(\mathrm{Y}_{\mathrm{i}, \mathrm{t}-1}\right)+\delta_{k} X_{i k t}+\varepsilon_{\mathrm{it}}
$$

where $t$ is the discrete time period, $Y_{i, t}$ denotes GDP per capita of province $i$ at period $t, \alpha_{i}$ are province time-invariant fixed effects - which represent the steady states, $k$ is the number of control variables. Commonly used covariates in $X$ include, but are not limited to, population growth, fertility rate, indicators for law and order, saving rate, years of schooling, trade openness, inflation, and democracy index (Barro et al 1991; Barro 2016). As the left-hand side of Equation (1) is the growth rate of GDP per capita over the period, a negative and significant estimate of $\beta$ is considered as evidence for income convergence. Compared to the cross-sectional approach, this has substantial advantages not only in terms of identifying the convergence dynamics but also being able to control for some unobserved variables.

One major caveat of the conventional convergence model, as Anselin (1991) points out, is the fact that provinces are treated as independent entities across space. If GDP per capita and other characteristics of one province potentially affect the outcomes of its neighbors, or if there are clusters in development, as suggested by the core-peripheral model of Krugman (1991) and Venables (2005), OLS estimates of Equation (1) and (2) are biased and inconsistent due to the omitted variable bias problems. In fact, this spatial dependence causes more severe biasedness in cross-province compared to cross-country studies due to the increasing popularity of regional growth policies (Elhorst, 2014).

According to Plumper and Neumayer (2010), there are three different forms of spatial effects. First of all, spatial lag model (SLM) implies that the pattern of spatial dependence arises from the dependent variable, or in other words, spatial dependence is "substantive". Secondly, spatial error model (SEM) assumes that the error term is the main source of dependence. In other words, it can be decomposed into two parts: one of which is spatially related and the other is i.i.d. Finally, if shocks in an explanatory variable in one entity produces spillover effects to outcomes of the neighbours, the non-spatial model can be extended in a similar manner. Ideally, to avoid omitted variable bias, we should include all three types of spatial effects discussed above in a general model specification. However, according to Anselin (2013), this general approach is problematic as it is impossible to identify the true underlying data generating process in some cases. Fingleton and Lopez-Bazo (2006) suggest modelling the spatial dependences among entities explicitly rather 
than implicitly through including them in the error term. The reason lies in the fact that we cannot correctly specify the spatial error model unless there is no omitted variable problem, which is very unlikely in our case. As a result, in the following specifications, we only consider spatial dependences in the dependent variable and explanatory variable.

\subsubsection{FDI agglomeration and spillover effects}

As FDI is a form of capital inflows, it should increase the marginal product of labour and hence household income in the recipient province and its neighbors. As pointed out in previous literature, this spillover effect happens because FDI projects bring not only jobs and capital but also more sophisticated technology and management know-how. Moreover, direct competition from FDI firms also encourages domestic firms to improve production efficiency (UNCTAD, 1999). This type of horizontal spillovers happens mainly among firms in the same industry. On the other hand, spillovers also occur across industries when FDI firms supply and buy inputs from domestic firms (Lall, 1978). Thanks to these two sources, over time, FDI can promote regional convergence in income levels, provided there is no barrier in the movements of goods and services between provinces, or any preferential policies towards some provinces over the others. Indeed, crossprovincial evidence from the People's Republic of China (PRC) suggests that regional differences in physical, human, and infrastructure capital, as well as FDI, help explain regional growth disparities (Fleisher et al., 2010). Of course, in reality, provinces are not made equal.

To understand the association between regional inequality and FDI, the challenge is also to disentangle the direct and spatial effects of FDI on regional differences in growth and income levels. Due to historical preferences and unequal development among provinces, the FDI placement tends to be endogenous and concentrated. It is thus important to account for the proximity to FDI location; some neighbouring provinces may reap a sizable spillover benefit, while others only a moderate one. In a cross-country setting, the evidence suggests export similarity among neighbors: a country is more likely to start exporting goods currently being exported by a neighbouring country (Bahar et al., 2014). We could also expect such localized character of knowledge diffusion in the case of FDI among neighbouring provinces within country.

Firms in general and FDI firms in particular are likely to locate near each other in space. From the

firm's point of view, this clustering behaviour is beneficial as geographical proximity can greatly 
foster the exchange of goods, people, and ideas among firms. In other words, agglomerations improve firms' productivity by allowing for better sharing, matching, and learning of production inputs and technology (Duranton and Puga, 2004). According to Tan and Meyer (2011), there are two main motives of FDI agglomeration: industry and country of origin. On the one hand, firms within the same industry benefit from the supply chain network, the joint pool of employees as well as intra-industry knowledge in terms of market forecasting or business trends. On the other hand, firms originate from the same country are also likely to locate near each other in order to exchange tacit knowledge and information on local business practice. This is particularly useful if FDI firms do not have local partners or if the institutional quality in the host country is weak while their businesses require a significant amount of trust.

In previous literature, positive externalities on firms' productivity produced by both types of agglomeration have been studied and found in many countries such as the UK (Driffield, 2004), France (Crozet et al, 2004), Portugal (Guimaraes et al., 2000) or Italy (Bronzini, 2004). However, to our best knowledge, the benefit of FDI agglomerations from the public point of view has received insufficient attention. We aim to bridge this knowledge gap by comparing both direct and spillover effects of industry and country of origin agglomerations towards provincial income convergence in Vietnam. In fact, richer knowledge on this issue would allow local and national governments to improve their attraction strategies. Specifically, we intend to test the following

hypothesis: As industry/activity agglomerations are naturally formed on a more economical basis compared to country-of-origin agglomerations, they can contribute more to provincial growth and the convergence process in general.

\subsubsection{Related studies}

The income convergence hypothesis has been tested and examined using different samples in previous literature. While conditional convergence has been found between countries (Barro et al., 1991; Ben-David, 1993), unconditional convergence has been found only among relatively homogenous entities such as US states (Vohra, 1996) or British counties (Chatterji, 1996). Treating entities as spatially dependent, convergence phenomenon has been detected using a sample of US states (Rey and Montouri, 1999), EU regions (Piras and Arbia, 2007; Badinger et al.,2004), or Chinese provinces (Aroca et al., 2006). However, studies on income convergence, the role of FDI 
or spatial interactions within Vietnam are limited. In fact, previous authors either look at periods before the FDI boom in 2007 (Nguyen and Nguyen, 2008) or convergence in productivity among industries (Nguyen et al., 2016).

In terms of the spillover effects of FDI capital, the evidence so far has been mixed. According to a meta-analysis by Gorg and Greenaway (2004), among 42 studies on the horizontal spillover effects of FDI in both developed and developing countries, positive and significant impact is found in only half of them. Reasons for these contradictory results include, but are not limited to, the absorptive capacity of domestic firms or competition levels in domestic markets (Wang and Blomstrom, 1992). On the other hand, supporting evidence of FDI vertical spillover is more conclusive. Consistent with the literature, previous studies on developing countries like Vietnam also suggest controversial results. While Mirza and Giroud (2003) argue that spillover effects are relatively weak, Nguyen and Nguyen (2008) find significant horizontal spillover in the service sector and vertical spillover in the manufacturing sector. Moreover, case studies on Vietnam mainly investigate effects across industries while largely ignore the role of geography. According to studies such as Crespo et al. (2012) or Hong and Sun (2011), as spatial externalities of FDI at provincial level are fairly strong, ignoring them can cause severe biasedness to the results.

In this chapter, we attempt to bridge the gap in income convergence as well as FDI spillover literature in Vietnam. Using provincial data from 2003-2015, we extend the basic panel model in Equation (2) above by treating provinces as spatially interdependent. We assume that FDI and its spatial lag are the main covariates that govern the convergence process. We also examine several specifications to improve the robustness of our results.

\subsection{Data}

We construct our final dataset using two main sources. Data on population and provincial GDP in current local currency are obtained from Vietnam General Statistics Office (GSO). To adjust for inflation, GDP values are deflated to the base year of $2010 . .^{5}$ Due to the unavailability of a province-specific consumer price index, we have to use the common national measure for this

\footnotetext{
${ }^{5}$ As commonly used by GSO
} 
adjustment. ${ }^{6}$ During the period of study, there were several administrative changes in Vietnam. Therefore, we incorporate data of newly created provinces into existing provinces in 2003 to construct a strongly balanced panel. Effectively, this leaves us with 60 provinces.

Total FDI capital of each province is calculated from the fDi Markets dataset, Financial Times Ltd. This is a comprehensive dataset which tracks worldwide greenfield FDI projects and collects information on location, activity, capital, and estimated number of jobs created, among many others. We use the nominal exchange rate to convert the value of FDI capital into local currency for consistency. Notably, as only implemented FDI projects are included, this dataset provides a more accurate measurement compared to registered capital which has been used intensively in previous studies for Vietnam. From a Balance of Payments point of view, this dataset effectively measures gross FDI inflows at provincial level, as it does not contain information on reverse investment or disinvestment. If the size of disinvestment is significant, our gross measure may overestimate the impact of FDI inflows compared to a net measure. Unfortunately, data on net inflows is not available at provincial level for Vietnam. However, Figure 2.5 shows that at national level, yearly gross and net FDI inflows are tracking each other extremely closely with a pairwise correlation of close to 0.99 . Moreover, disinvestment only accounts for a relatively small part of total FDI inflows. Therefore, our strategy of using aggregated project-level data to measure provincial FDI inflows should not suffer from the above caveat, if we assume that the disinvestment behaviors of FDI firms are independent of their locations.

In order to examine potential heterogeneity in spillover effects, we decompose FDI using the Statistical Classification of Economic Activities - NACE revision 2 (Eurostat, 2014). The first group, low-tech FDI, consists of projects in low-technology manufacturing and less knowledgeintensive services such as textile and warehousing. The second group, high-tech FDI, involves high-technology and knowledge-intensive counterparts such as chemicals and R\&D. ${ }^{7}$ Finally, supplementary variables such as exchange rate or national GDP deflators are extracted from World Development Indicator (WDI), World Bank.

\footnotetext{
${ }^{6}$ We acknowledge that doing so might introduce measurement errors to the real level of GDP per capita as well as growth rates if purchasing power parity does not hold among provinces (Barro et al., 1991). However, unfortunately data on provincial CPI is not publicly available.

${ }^{7}$ The detailed list can be found in the Appendix
} 


\subsection{Methodology}

\subsubsection{Spatial weighting matrix}

The spatial weighting matrix $\mathrm{W}$ is an $\mathrm{N} \times \mathrm{N}$ square matrix which represents the spatial structure or the relative connectivity of entities across space (Getis, 2009). The structure of W evokes the first law of geography by Tobler (1969): "everything is related to everything else, but near things are more related than distant things". In practice, there are two main strategies in constructing W. Firstly, the binary method assigns the value of 1 to $w_{i k}$ if province $i$ and $k$ are contiguous and 0 otherwise. Secondly, in the distance-based method, $w_{i k}$ represents the inverse distance between two provinces' centroids. In both methods, all diagonal elements are set to 0 to avoid selfcontiguity and the matrix is row-standardized, i.e., the sum of all elements on each row is 1.In this study, we utilize the inverse-distance version of $\mathrm{W}$ with a cut-off threshold of $500 \mathrm{~km}^{8}$ - which effectively means that $w_{i k}$ become 0 for any distance exceed this value. Firstly, using this type of $\mathrm{W}$ is justifiable due to the long and thin geographical shape of Vietnam. Therefore, using contiguity weights might ignore some spatial dependences especially those that happen among provinces in the middle, narrow part of the country. Secondly, using the inverse distance matrix without any cut-off threshold is highly problematic and counterintuitive as it requires the assumption that all provinces are connected to each other (Lesage, 2014). ${ }^{9}$

\subsubsection{Model}

We examine the income convergence in Vietnam conditioning on FDI capital inflow using spatial econometrics approach. The impacts of FDI are estimated by including both level and spatial lags as explanatory variables. Moreover, we disentangle the potential heterogeneity of FDI impacts by their technology levels and agglomeration motives.

\footnotetext{
${ }^{8}$ We use the longitude and latitude of the capital of each province to calculate the distance. Although this choice may slightly violate the exogeneity assumptions of $\mathrm{W}$, we believe that it reflects the economic linkages among provinces more precisely.

${ }^{9}$ The choice of this cut-off value is entirely arbitrary except from the fact that it ensures there is no province without neighbours. However, we have observed that using different values do not alter our main estimation significantly. More detailed results are available upon request.
} 


\subsubsection{FDI technology levels and income convergence}

Firstly, we begin with a baseline dynamic panel model with two-way fixed effects and without any spatial components:

$$
Y_{i, t}=(1+\beta) Y_{i, t-1}+\sigma F D I_{i, t-1}+\gamma \ln \left(n_{i, t}+g+\delta\right)+\alpha_{i}+\mu_{t}+\varepsilon_{i, t}
$$

where:

$Y_{i, t}$ is the logarithm of GDP per capita in province $i$ and time $t$

$F D I_{i, t-1}$ is the logarithm of FDI inflows in province $i$ and time $t-1$

$n_{i, t}$ is the population growth rate in province $\mathrm{i}$ and time $\mathrm{t}, \mathrm{g}$ is the exogenous rate of technological progress and $\delta$ is the capital depreciation rate, which we assume to be constant across provinces ${ }^{10}$

$\alpha_{i}$ and $\mu_{t}$ are province and time fixed effects which capture any time-invariant heterogeneity and common temporal shock to all provinces.

$\varepsilon_{i, t}$ is the error, which we assume to be i.i.d

We then extend our baseline model by accounting for potential spatial dependences among Vietnamese provinces. Specifically, we gradually include the spatial lag of log GDP per capita and FDI inflows:

$$
\begin{gathered}
Y_{i, t}=\rho \sum_{k=1}^{N} \omega_{i, k} Y_{i, k, t}+(1+\beta) Y_{i, t-1}+\sigma F D I_{i, t-1}+\gamma \ln \left(n_{i, t}+g+\delta\right)+\alpha_{i}+\mu_{t}+\varepsilon_{i, t} \\
Y_{i, t}=\rho \sum_{k=1}^{N} \omega_{i, k} Y_{i, k, t}+(1+\beta) Y_{i, t-1}+\sigma F D I_{i, t-1}+\theta \sum_{k=1}^{N} \omega_{i, k} F D I_{k, t-1}+\gamma \ln \left(n_{i, t}+g+\delta\right)+\alpha_{i}+\mu_{t}+\varepsilon_{i, t}(5)
\end{gathered}
$$

Equations (4) and (5) are commonly referred to as the Spatial Autoregressive (SAR) and Spatial Durbin (SDM) models. In matrix form, equations (3), (4), and (5) are equivalent to:

\footnotetext{
${ }^{10}$ Following Bosworth and Collin (2008)'s paper on income convergence in China and India, we assume that $g$ equals 0.04 and $\delta$ equals 0.06 .
} 


$$
\begin{gathered}
Y_{t}=(1+\beta) Y_{t-1}+\sigma F D I_{t-1}+X_{t}+E_{t} \\
Y_{t}=\rho W Y_{t}+(1+\beta) Y_{t-1}+\sigma F D I_{t-1}+X_{t}+E_{t} \\
Y_{t}=\rho W Y_{t}+(1+\beta) Y_{t-1}+\sigma F D I_{t-1}+\theta W F D I_{t-1}+X_{t}+E_{t}
\end{gathered}
$$

We use the Maximum Likelihood (ML) method for both the baseline and the dynamic spatial models. ${ }^{11}$ According to Elhorst (2010), Monte Carlo simulation shows that ML method is capable of producing a less biased estimator for the spatial autoregressive parameter $\rho$. Consistent with the literature, a negative and significant estimate of $\beta^{12}$ provides evidence for income convergence conditioning on FDI inflows. We use two indexes to illustrate the convergence process. Firstly, the speed of convergence, which is calculated as $-\ln (1+\beta)$ and reported in annual percentage, indicates how fast provinces approach their steady states. Besides, the half-life indicator, which equals $\ln (2) /-\ln (1+\beta)$, measures the time it takes for provinces to fill half the gap separating them from their steady states. Ideally, we should control for the saving rate and human capital accumulation. However, in the case of Vietnam, the proxies for these variables are not available at provincial level. Finally, we use one-period lagged of FDI inflows since our dataset is constructed based on the announcement of FDI projects and thus we expect their impacts to not be instantaneous. In fact, lagging FDI by one period also allows us to deal with the endogeneity problem between FDI and GDP per capita, at least to some extent. Estimates of $\rho$ identify substantive dependence among provinces. On the other hand, $\sigma$ and $\theta$ represent the direct and spatial spillover effects of FDI inflows on GDP per capita, respectively. Interpreting coefficients in equation (6) is straightforward as $\rho$ is assumed to be zero. However, in equation (7) and (8), if $\rho$ is significantly different from zero, we cannot directly use the estimates of $\beta, \sigma$ and $\theta$ to infer about the direct and indirect effects. In fact, we can write equation (8) in reduced form as follows:

$$
Y_{t}=(1-\rho W)^{-1}(1+\beta) Y_{t-1}+(1-\rho W)^{-1}(\sigma I+\theta W) F D I_{t-1}+(1-\rho W)^{-1} X_{t}+(1-\rho W)^{-1} E_{t}
$$

Following this transformation, the direct impact of FDI on income and the convergence coefficient can be calculated using the average of all diagonal elements of the composite matrices $(1-\rho W)^{-1}$

\footnotetext{
${ }^{11}$ We use Stata command xsmle (Belotti et al., 2016) for estimation

${ }^{12}$ Or in other words, $1+\beta$ is smaller than 1
} 
$(\sigma I+\theta W)$ and $(1-\rho W)^{-1}(1+\beta)$, respectively. On the other hand, the spillover effects are calculated by the average row-sum of all non-diagonal elements of the corresponding matrices. In the tables of results below, we report these transformed effects if necessary. Standard errors for hypothesis testing are obtained using Monte-Carlo simulation with 1000 replications.

In order to examine the heterogeneity of FDI impact by the projects' embedded technology levels, we extend equations (6), (7), and (8) by including two measures of low-tech and high-tech FDI inflows. The rest of the specification is completely similar.

\subsubsection{FDI agglomerations and income convergence}

Equivalently, we investigate the heterogeneity of FDI contribution towards provincial income convergence by types of agglomeration: industry and country of origin. In order to disentangle these two agglomerations in each province at any given time, we implement a two-stage approach. In the first stage, using panel Poisson count model, we regress total number of FDI projects on two indexes for industry and country of origin agglomerations. As the number of FDI projects involves a lot of 0 values and is not normally distributed, Poisson regression is preferable over OLS for better consistency and lower biasedness:

$$
F D I_{i, t}=\beta_{0}+\beta_{1} \text { Industry }_{i, t-1}+\text { Origin }_{i, t-1}+\varepsilon_{i, t}
$$

where:

$F D I_{i, t}$ is the total number of FDI projects in province $i$ at year $t$.

Industry $_{i, t-1}$ and Origin $_{i, t-1}$ are agglomeration indexes, proxied by the ratios of existing local FDI firms in all previous years within the same industries or countries of origin as the group of new FDI firms in year $t$.

For example, if there are 10 projects in province $i$ and year $t$, in which 4 are from the China and 6 are from Japan, the origin index Origin $_{i, t-1}$ is calculated by the number of existing Chinese and Japanese firms divided by the number of existing FDI firms in the province up until year $t-1$. Similarly, if out of those 10 projects, there are 2 in agriculture and 8 in manufacturing, the industry 
index Industry I $t-1_{1}$ is calculated by the number of already established agricultural and manufacturing firms divided by the total number of existing FDI firms in the province up until year $t$-1.There are three things worth noting. Firstly, we use total count of FDI projects as the dependent variable instead of total capital value. This is because apart from provincial characteristics, FDI capital depends on many other firms' characteristics, which unfortunately we cannot control for due to data limitation. Secondly, we divide total number of agglomerating firms by total number of all FDI firms in previous years before including them as explanatory variables. Particularly, doing so allows us to standardize the accumulative nature of FDI stock over time. Finally, by relying only on agglomeration indexes to explain the count of FDI projects, we assume that all firms face the same provincial characteristics while forming their investment decisions. Even though this is a strong assumption given Tan and Meyer's (2011) results, we proceed as our focus is not on how strong the agglomeration forces are but rather their relative importance.

In the second stage, we successively set each index to be zero and predict the total number of FDI projects using the other based on the first-stage coefficients. These values can serve as proxies for agglomeration forces as they measure the predicted number of projects in province $i$ at year $t$ if none of the existing local FDI firms are from the same countries of origin or industries. We then substitute them into the baseline and spatial models described above to measure the heterogeneous effects of FDI agglomeration in a similar manner to the technology levels.

Although Tan and Meyer (2011) only refer to industry agglomeration as firms that have the same products, we have reasons to believe that firms that have similar activities such as building warehouses or R\&D also tend to cluster together. In this kind of agglomeration, except for exchanging industry-specific knowledge, firms still achieve economies of scale through sharing the supply network and pool of employees. Therefore, we also examine the importance of activity agglomeration relative to country-of-origin agglomeration in a similar manner for robustness. ${ }^{13}$

\footnotetext{
13 The full lists of industry and activity are included in the Appendix
} 


\subsection{Results}

\subsubsection{Preliminary analysis}

In order to provide a solid foundation for the spatial models, we conduct a preliminary analysis of the patterns of Vietnamese provinces' GDP per capita over time. We measure the association between the provincial GDP per capita and the spatial lag or weighted average of its surrounding neighbors using the Global Moran's I statistic. ${ }^{14}$ This is one of the most commonly used statistics in detecting spatial dependence (Arbia, 2006) and (Kelejian and Piras, 2017). In Vietnam, spatial dependence among provincial GDP per capita is fairly strong as the Moran's I statistic has been positive and significant with p-value very close to zero since 2003 (Table 2.1). In other words, provinces with similar GDP per capita are more likely to locate near each other than what can be expected by random chance. Therefore, it is not reasonable to treat provinces as independent entities in space.

Plotting the Global Moran's I statistic and the coefficient of variation - which represents the dispersion of provincial GDP per capita over time - reveals two intriguing facts (Figure 2.6). Firstly, although the spatial dependence has been decreasing since 2003, it remains highly significant which suggests that clusters in GDP per capita do exist among Vietnamese provinces. Secondly, the clustering effect and dispersion among provinces tend to move together. ${ }^{15}$ This can be due to either the fact that provinces within clusters become more similar to each other or the vanish of existing clusters, or both. As Global Moran's I statistic summarizes all spatial dependences using a single number, it is not particularly useful for identifying potential clusters. As a result, we turn our attention towards the Local Moran's I statistic for each province over time to examine the changes within and across clusters more closely. ${ }^{16}$

\footnotetext{
${ }^{14}$ Global Moran's I statistic is calculated as $G M=\frac{\sum_{i=1}\left(Y_{i}-\bar{Y}\right) \sum_{j=1} \omega_{i, j}\left(Y_{i}-\bar{Y}\right)}{\sum_{i=1}\left(Y_{i}-\bar{Y}\right)^{2}}$ where $\omega_{i, j}$ is the elements of the rowstandardized spatial weights matrix W; $Y_{i}$ is the GDP per capita of province $\mathrm{i}$, and $\bar{Y}$ is the mean GDP per capita of all provinces.

${ }^{15}$ Indeed, these two measures are highly correlated with a coefficient of 0.77

16 The Local Moran's I statistic is calculated as $I_{i}=\frac{\left(Y_{i}-\bar{Y}\right) \sum_{j=1} \omega_{i, j}\left(Y_{i}-\bar{Y}\right)}{\sum_{i=1}\left(Y_{i}-\bar{Y}\right)^{2}}$. This is a good representative of the standardized spatial lag of provincial GDP per capita
} 
We plot the Local Moran's I statistic for each province on the map (Figure 2.7) and also against the standardized GDP per capita (Figure 2.8) for three representative years along the period of study. By doing so, we effectively divide provinces into four distinct groups: The high-income province with high-income neighbors; the high-income province with low-income neighbors; the low-income province with low-income neighbors; the low-income province with high-income neighbors. ${ }^{17}$ We define high income (rich) as being higher than the average while low income (poor) as being lower than the average. Looking at Figure 2.7, in 2003 - the first year of our interest, there existed four clusters of provinces: The Northeast (poor), the Mekong river delta (rich), the Northwest (poor), and the Southeast region (rich). From the income convergence's point of view, these clusters are particularly alarming as it means that some provinces are getting away while some are lagging behind. However, over time, while the first two clusters have disappeared, the former two have also shrunk in size despite their persistence. Figure 2.8 also reveals another interesting trend. Throughout the period of study, the majority of provinces has become more and more scattered around the point of origin - or in other words, has converged towards the "averaged" province. Moreover, the Local Moran's I statistics for many provinces within the persistent clusters have vastly reduced since 2003 .

We can summarize our preliminary analysis on the regional pattern of GDP per capita in Vietnam using two stylized facts. Firstly, even though spatial dependences among provinces have decreased over time, they remain fairly strong and thus need to be considered in the empirical analysis. Secondly, there is significant evidence which supports the income convergence process among Vietnamese provinces.

\subsubsection{Empirical analysis}

\subsubsection{FDI technology levels and income convergence}

Table 2.2 reports the panel regression results using both baseline and spatial models. In all specifications, the significant and negative estimation of the $\beta$ coefficient provides strong support for income convergence. Together with the decreasing coefficient of variation as depicted in Figure 2.6, it is fairly sensible to conclude that the convergence process has offset any shock to

\footnotetext{
17 These are corresponding to the first, second, third and fourth quadrant in Figure 2.8, respectively
} 
the dispersion of income and successfully reduced regional inequality in Vietnam during the period of study. However, as growth in general and the convergence process in specific highly depends on business cycles, whether Vietnam can maintain this trend in the future remains questionable.

When only lag GDP per capita, population growth and FDI are included as in column (2), the convergence speed is 11.2 percent which implies that it would take 6.2 years for Vietnamese provinces to close half the gap to their steady states. This speed is relatively high compared to the commonly founded 2 percent in previous literature (Abreu et al., 2005) but is consistent with what has been observed among provinces in other developing countries such as China (Hong and Sun, 2011) or Turkey (Celbis and Crombrugghe, 2016). Interestingly, the significant estimation of FDI capital confirms its positive impact on provincial income. More specifically, 10 percent increase in FDI inflows is associated with 0.005 percent increase in provincial GDP per capita the following year. However, it is not sufficient at this point to conclude about the contribution of FDI in the convergence process. In fact, if FDI capital is concentrated in the rich provinces only then this result may even imply that FDI causes income divergence among provinces.

We tackle this issue by extending our baseline model to account for the spatial dependence among provinces. First of all, we estimate a spatial autoregressive (SAR) model by adding the spatial lag of provincial GDP per capita, as reported in columns (3) and (4). The coefficient of this new term is positive and highly significant at 5 percent level which conforms with the strong spatial dependence we notice in the preliminary analysis. In other words, provinces which are closer to each other are more likely to have similar development levels compared to those further away. We support this finding by using arguments from Krugman (1991) and Rey and Montouri (199) in which geographical closeness is highly capable of fostering convergence by allowing for better exchange of technology, goods, and workers. Particularly, the speed of convergence increases to around 12.8 percent with a corresponding half-life of 5.4 years which suggests that the spatial dependences among provincial GDP per capita play an important role in the convergence process by shortening the average time needed to reach the steady states by around 1 year. If we treat provinces as independent entities across space as in the baseline model, the estimation of $\beta$ coefficient is biased as it also captures these underlying spatial interactions. Interestingly, we can partially attribute this 1-year improvement to FDI due to its positive and significant estimation in both columns (3) and (4). More specifically, throughout the period of study, although FDI capital 
has mainly been located in some rich provinces, it has accelerated the convergence process through raising host provinces' income and providing the foundation for the spatial interactions to work. A clear policy implication would be that the Vietnamese governments should devote considerable resources to improving the connections among provinces. Building transport infrastructure or reforming the household registration system are two examples of what can be done in order to magnify this impact.

Apart from this indirect channel through host province's GDP per capita, FDI capital can also directly contribute towards the convergence process thanks to the spillover effects. Specifically, a newly opened FDI factory in host provinces can considerably benefit the neighboring provinces through providing jobs and income for commuting workers, setting up new supply chains, or improving the overall infrastructure quality. We test this possibility in column (5) by adding the spatial lag of FDI to the existing SAR model. By doing so, we implicitly assume that these effects diminish with distance. Intriguingly, this new term is positive and highly significant at 5 percent level which provides concrete support for the relevance of FDI spillover. Even if FDI is more concentrated in rich provinces, these positive FDI spillover effects would help shorten the convergence process among provinces. Moreover, we also observe that the coefficient of spatial lagged FDI is substantially higher than that of FDI itself. ${ }^{18}$ which is consistent with the law of diminishing marginal product of capital given the concentration of FDI capital in rich provinces. This also provides even more concrete evidence on the contribution of FDI capital towards the convergence process.

Finally, we investigate the potential heterogeneous impact by effectively dividing FDI capital into two groups with respect to their embedded technology levels. As expected, high-tech FDI is highly relevant in accelerating the convergence process, both directly through the spillover effects and indirectly as a positive determinant of provincial GDP per capita. For example, in the SDM specification in column (7), 10 percent increase in high-tech FDI is associated with 0.01 percent increase in the host province's GDP per capita and 0.04 percent increase in the average neighboring provinces' GDP per capita. In contrast, the impacts of low-tech FDI are insignificant in both specifications. A possible explanation of this observation is that in developing countries, low-tech

\footnotetext{
${ }^{18}$ As mentioned above, for the SAR and SDM model, we report the reduced form estimates when necessary.
} 
FDI can sometimes be detrimental to growth by producing market-stealing or crowding-out effects on domestic firms (Hong and Sun, 2011). As a result, we strongly believe that the quality of FDI does matter in the catch-up process and Vietnamese provinces should attract FDI more selectively in order to maximize the potential benefit.

\subsubsection{FDI agglomerations and income convergence}

Table 2.3 presents the first-stage results for the agglomeration study. As expected, the coefficients of all three agglomeration indexes are positive and highly significant in Vietnam. This confirms the clustering behaviour by province of FDI firms in Vietnam to reap the benefit of agglomeration economies, as theory suggests. In other words, the larger the stock of the same country or same industry/activity FDI firms in previous years, the higher the number of new FDI firms decide to locate. Interestingly, country of origin agglomeration seems to be the dominating force that pulls FDI firms together in both columns (1) and (2). This can be explained, at least to some certain extent, by the high degree of business uncertainty and weak local institutional quality in Vietnam. ${ }^{19}$

Table 2.4 reports the second-stage results for both the baseline and spatial models. Similarly, failing to account for the spatial dependences among provinces leads to biased estimation of the convergence speed. As far as the agglomeration types concern, industry and activity agglomerations have considerable contributions towards the convergence process, both directly and indirectly through positive spatial interactions. Contrastingly, the insignificant coefficients of country-of-origin agglomeration in all columns suggest that its impact is limited. Moreover, the negative sign suggests that it may even be harmful to the catching-up process by inducing the crowding-out effect in a similar manner to low-tech FDI. These observations are consistent with theories as industry/activity agglomerations are formed on a more profit-based foundation compared to their country of origin counterparts. As a result, it is reasonably clear that policies which promote FDI clusters such as building industrial parks or processing zones should be the main focus of both local and national authorities in Vietnam.

\footnotetext{
${ }^{19}$ According to Tan and Meyer (2011), "in hostile territory, you need your friends the most"
} 


\subsubsection{Prospective FDI and income convergence}

Up until now, we have used one-period lagged of FDI inflows as explanatory variables to reflect the potential delay between the announcement of the project and its real impact. However, in this section, we examine whether the positive contribution of FDI capital towards provincial income and consequently the convergence process can also be contemporaneous. There are two possible reasons for this. Firstly, given the size of most FDI projects, workers and service providers may move into the province or increase their economic activities right after the announcement to anticipate the potential aggregate demand shock. Secondly, as we do not have data on the month of announcement, the one-year lagged value may not capture the full extent of FDI's impact. ${ }^{20}$

The first column of Table 2.5 presents the results of our baseline model with the inclusion of FDI capital for the current year ("Current FDI"). In the second column, we go one step further and also include its lead value to capture the potential signaling effect of FDI capital i.e. the future presence of FDI project within one province may be known even before the official announcement. To reflect the anticipated nature of this variable, we call it "Prospective FDI". We only present the results of the SDM model with the assumption that this is the correct specification of the data generating process. Generally, it is evident that both current and prospective FDI do contribute towards the income convergence process through their impacts on the host province's GDP per capita (first panel). On the other hand, their impacts through direct spatial spillovers are both insignificant (second panel). In terms of magnitude, the lag FDI remains the most relevant, followed by current and prospective FDI, respectively. However, it is important to be cautious when forming policy implications from these results. Given the p-values of the Inoue and Solon's (2006) Lagrange Multiplier test ${ }^{21}$, there is evidence of autocorrelation of orders 1 and 2 in the FDI variable. Therefore, the positive results in our estimation may just be a consequence of the positive correlation of provincial FDI over time.

\footnotetext{
${ }^{20}$ For example, a FDI project is announced in January may see its impact reflected in the provincial income for that year.

${ }^{21}$ The null hypothesis is no autocorrelation of any order
} 


\subsubsection{FDI and consumption convergence}

In previous specifications, we have found that FDI capital can accelerate the convergence process and reduce income inequality between Vietnamese provinces. However, income, as measured by GDP per capita, may not be the best indicator of households and individual wellbeing and therefore income inequality may not reflect well the dispersion in living standards. The reason is that income is much more volatile, as it completely misses out on people's saving patterns. Deaton (1998) advocates for consumption as an alternative and better measure as it directly captures the flow of goods and services. Moreover, it is also more likely to be affected by changes in benefits and welfare programs (Meyer and Sullivan, 2017). In recent years, there has been a growing number of studies comparing patterns in income and consumption inequality. However, the results are mixed (Heathcote et al, 2010, Attanasio et al., 2012, Fisher et al. 2013, Aguiar and Bils, 2015).

In this section, we re-estimate our model using consumption measure as dependent variable instead of income to see whether we can find a similar impact of FDI capital. Due to data limitation, we use the retail trade of goods and services statistics from the General Statistic Office ${ }^{22}$ as a proxy for consumption and consumption per capita. It is important to note that this is only a close proxy and by no mean a perfect measure of consumption as it also includes government spending and value of sellers' shipments and inventories which have not been sold to consumers. In many statistical agencies such as Eurostat or the Office of National Statistics (United Kingdom), monthly data of retail trade of goods and services are often used as a short-term indicator for private consumption. In Vietnam, the General Statistics Office (GSO) produces private final consumption expenditure statistics using a combination of data from estimated retail trade of goods and services, production and use of agricultural products, and household living standards survey. Figure 2.9 shows that retail trade of goods and services is a sufficiently good proxy for private consumption as the year-on-year growth rates of the two variables are highly similar at national level. Another potential proxy for consumption is personal remittances received as a percentage of GDP. According to the World Development Indicators (WDI), personal remittances received as a percentage of GDP for Vietnam have increased significantly since mid-2000 and have continuously been around 6-7 percent. Unfortunately, remittance data is not currently available at

22 https://www.gso.gov.vn/SLTKE/pxweb/en/08.\%20Trade,\%20Price\%20and\%20Tourist/-/E08.02.px/?rxid=5a7f4db4634a-4023-a3dd-c018a7cf951d 
provincial level - our main unit of interest. Therefore, in Table 2.6 and 2.7, we present the results using retail trade of goods and services as proxy for consumption, for both the baseline and spatial models, and both aggregate and breakdown measures of FDI by technology levels and agglomeration types.

Firstly, the speed of convergence is much faster for consumption per capita with a half-life of around 3 years compared to around 5.5 years for income per capita. However, the spatial interactions among provinces are much less significant, as shown by the estimated coefficient of the spatial lag of consumption per capita. We also find weaker evidence of its contribution towards the convergence process. Even though the coefficients of high-tech FDI or industry activity FDI agglomerations are still positive and significant, the lack of spatial dependences among provincial consumption per capita may prevent them from bringing provinces closer together. In terms of the direct spillover effects, as measure by the spatial lag of FDI in SDM model (columns 2 and 4 in both tables), only industry activity remains relevant in the convergence process. These findings further reinforce the policy implication from section 2.5.2.2, that both local and national governments in Vietnam should devote sufficient resources to promoting FDI activity clusters, through building new industrial parks and increasing the capacity of the existing ones.

\subsection{Robustness checks}

\subsubsection{FDI as an endogenous variable}

One potential issue which may affect our results is the endogeneity of FDI - our main explanatory variable. As discussed in section 2.4.2 above, GDP and FDI may be simultaneously determined. While FDI can contribute to the level and growth rate of GDP per capita at provincial level, GDP per capita can also be a key determinant of foreign firms' investment decisions. On the one hand,

if GDP per capita is a good proxy for development level and subsequently the skill level of the local workforce, higher GDP per capita may cause higher FDI inflows. On the other hand, GDP per capita is also an indicator of the potential labour cost facing FDI firms. If this is the case, higher provincial income per capita may discourage FDI inflows. In any case, this type of reverse causality may cause bias in our results. This can also be an issue for the spatial lagged value of FDI inflows as GDP in the host province may also affect FDI inflow in surrounding provinces if 
the labour force is sufficiently mobile. In our main model, we have attempted to treat this problem by using publicly announced deal-level data to compute provincial FDI inflows and also including the lagged values of FDI inflows instead of the contemporaneous ones.

In this section, we provide robustness checks by explicitly treating provincial FDI inflows and its spatial lagged value as endogenous. We implement an instrumental variable approach in a system GMM set up in which lagged values of the endogenous FDI inflows are used as instruments (Arellano and Bond, 1991; Roodman, 2006) ${ }^{23}$. As FDI inflows enter the model as a 1-year lagged value, we are only using lags of second-order and higher. Standard errors of estimated are created using the two-step method and Windmeijer's (2005) small sample correction. Table 2.8 presents results for the baseline model with high-tech and low-tech FDI inflows as the key variables of interest. Generally, the results are qualitatively similar to our main results using the quasimaximum likelihood estimator. Only high-tech FDI can contribute to the income convergence process, both indirectly as a determinant of GDP per capita, and indirectly through spatial spillovers. The p-values for the Arellano-Bond AR(2) and the Hansen test in both models provide strong support for the use of second-order and higher lags as instruments as well as their validities.

\subsubsection{Alternative specifications}

We also test the robustness of our results using (i) the contiguity spatial weighting matrix to allow for different forms of spatial dependences as well as (ii) three-year interval averaged data to account for the impact of business cycles in the conventional growth model. Table 2.9 and 2.10 report regression results using FDI classification by technology levels and agglomeration motives, respectively. In general, our main findings remain generally intact. Only high-tech FDI and FDI industry/activity agglomerations can accelerate the convergence process. However, the insignificances of some estimations of the spatial dependences and FDI capital suggest that relying on FDI and spatial interactions among provinces may not be a sustainable growth strategy, at least in the long run.

\footnotetext{
${ }^{23}$ We use command xtabond2 (Roodman, 2006) for estimation
} 


\subsection{Conclusion}

For our discussion, several qualifications are in order. First, we are interested in not only the adjustment of household income and convergence process influenced by FDI, but also the economic agglomeration as FDI localizing production and service activities in the nearby regions. Second, the focus on understanding the effect of FDI for the average province is important since it is possible that well-developed provinces benefit more from FDI through having greater gravity for economic activities while other less-developed provinces decline. Finally, even though we have made every possible effort within the data availability, endogeneity remains a viable problem as the locational choice of FDI over time depends on many unobserved factors including initial conditions, preferential treatments, and political economy considerations.

In this chapter, we study the association between FDI, income convergence, and regional inequality in Vietnam. Applying spatial econometrics approach on provincial data from 20032015, a period which can be characterized by trade and investment openness, our findings provide supporting evidence of income convergence among provinces in Vietnam. Together with the decreasing trends in provincial income dispersion, this catching-up effect has significantly contributed to regional inequality reduction. Particularly, spatial interactions among provinces play a substantial role in accelerating the convergence process. We also find the positively significant contributions of high-tech FDI and industry/activity FDI agglomeration but not lowtech FDI or country of origin agglomeration; probably due to the fact that low-tech foreign investment competing away domestic firms without significant productivity and efficiency gains while country of origin agglomeration may crowding-out domestic investment.

In terms of policy implications, provinces in Vietnam should be highly selective in attracting FDI projects as a sustainable growth strategy. Moreover, they should also devote sufficient resources to policies which induce industry/activity FDI agglomerations such as building industrial parks or processing zones. Finally, the national government also needs to promote the flow of goods and workers among provinces by improving infrastructure quality or possibly reforming the household registration system.

Since Vietnam started opening to international trade and financial markets, the central government has mainly used tax incentives including preferential tax rates and tax breaks in order to distribute 
FDI capital more equally among provinces. According to Deloitte's (2020) Doing Business in Vietnam report ${ }^{24}$, FDI firms are subjected to only 17 percent corporate income tax for 10 years, compared to the standard 20 percent rate if they invest in difficult socio-economic regions. Moreover, they also receive 2 years of tax exemption and 4 years of 50 percent reduction. If FDI firms are investing in especially difficult socio-economic regions, the tax rate drops to only 10 percent for 15 years with a tax holiday of 4-year exemption and 9 years of 50 percent reduction. However, as shown in Figure 2.4, the extremely unequal distribution of FDI capital among Vietnamese provinces for the last 15 years suggests that tax incentives have not been effective as a policy tool. Unless other barriers to investment such as labour immobility and poor infrastructure are lifted, financial incentives would not be sufficient to attract FDI firms to the least-developed regions.

Based on the spatial-effect estimation applied to a new data set and empirical setting, useful methodological extension may include: (i) reducing estimation bias of the convergence coefficient by controlling for a larger set of covariates; and (ii) improving the accuracy of FDI spillover measurement by incorporating socio-economic and institutional distance among provinces into the spatial weighting matrix.

${ }^{24} \mathrm{https://www2.deloitte.com/content/dam/Deloitte/vn/Documents/tax/vn-tax-vietnam-doing-business-2020.pdf}$ 


\section{Figures and Tables}

Growth (right scale) has been rapid yet robust for Vietnam thanks to a strong exports performance (left scale)

Source: World Bank WDI

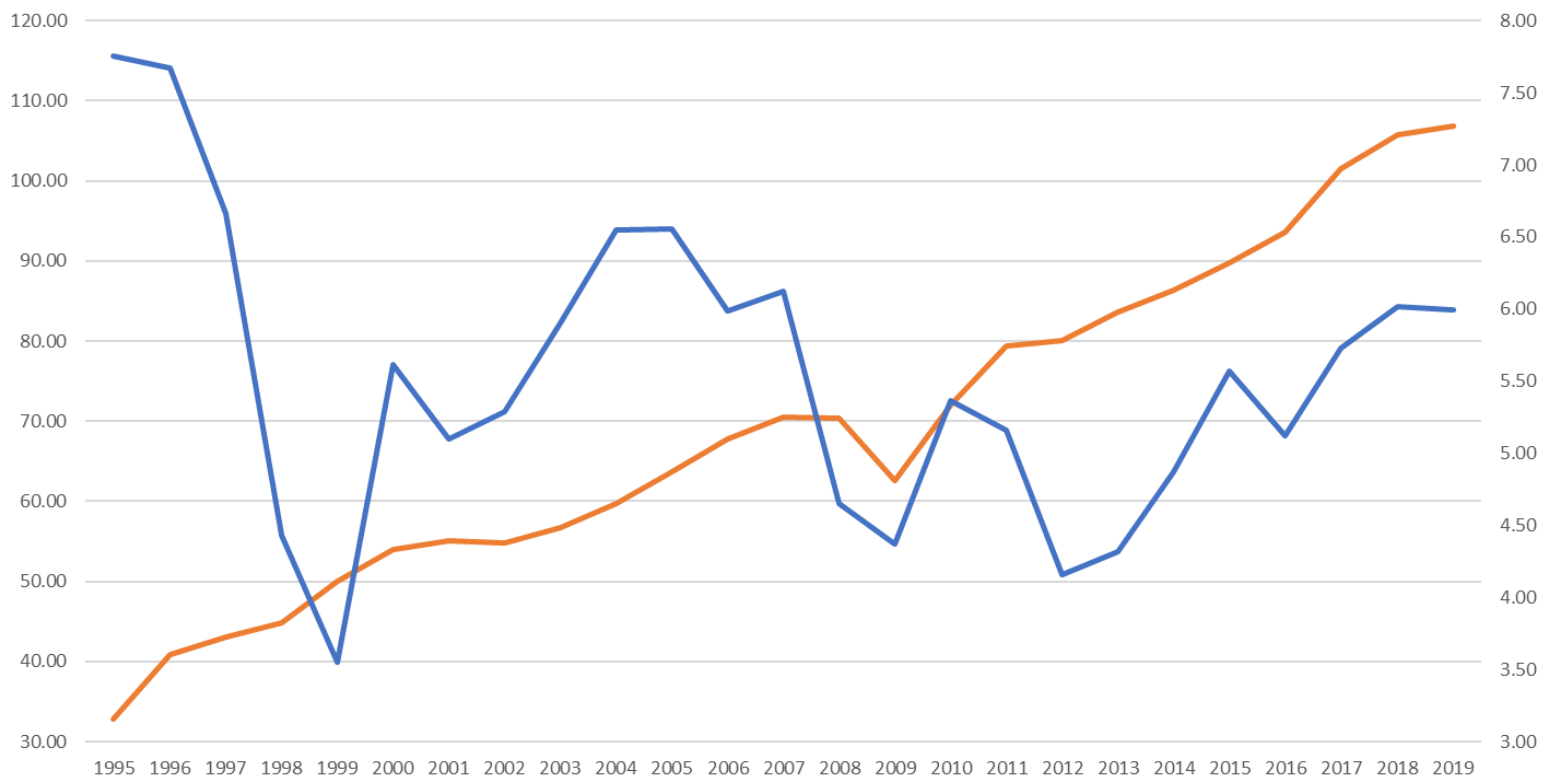

Exports of goods and services (\% of GDP) _ GDP per capita growth (annual \%)

Figure 2.1 Vietnam's export and GDP growth

Source: World Development Indicators 
Vietnam's exports have been increasingly depending on manufacturing and FDI sectors

Source: World Bank WDI and GSO

90.00

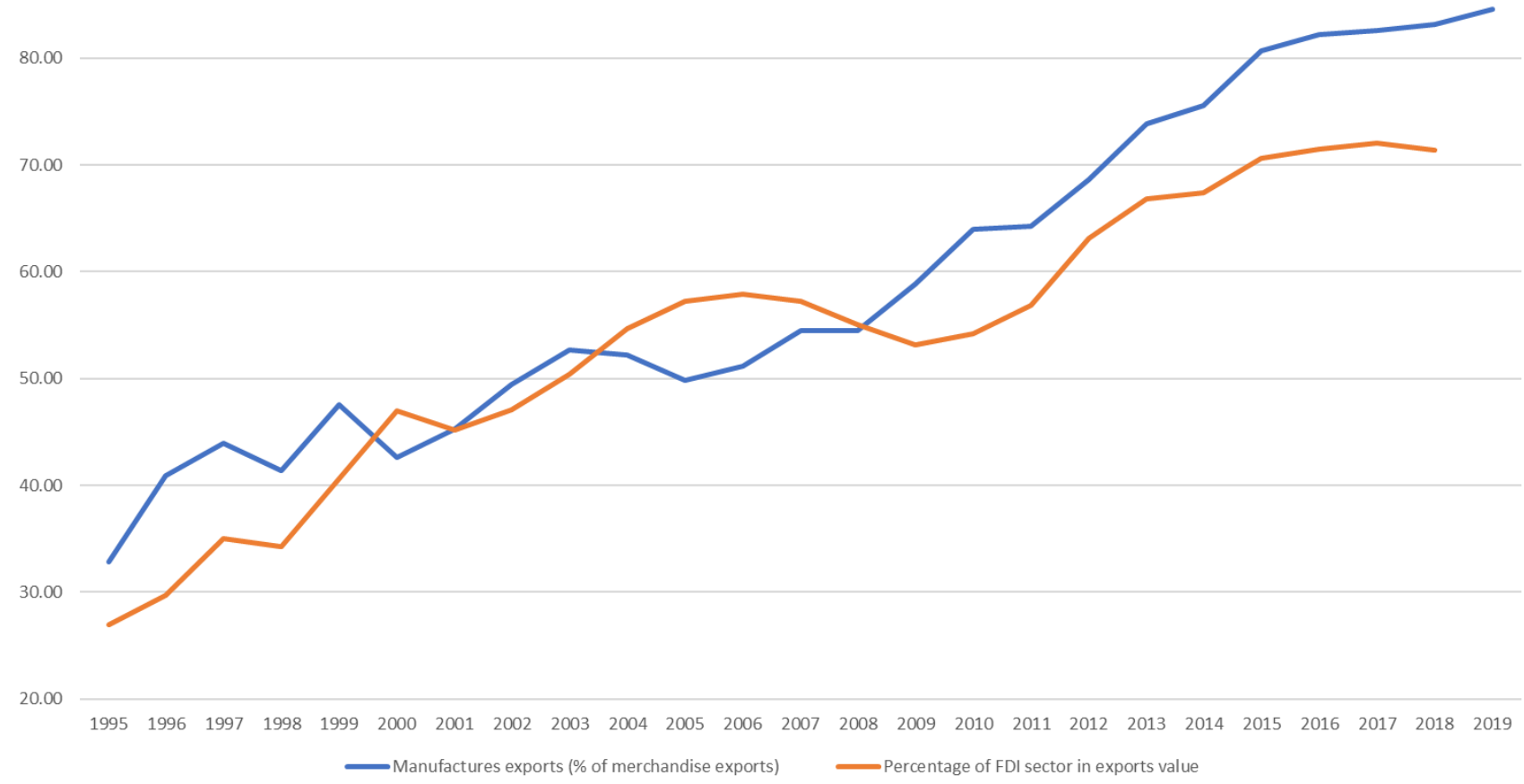

Figure 2.2 Vietnam's export composition

Source: World Development Indicators and GSO 
FDI firms bring to Vietnam a massive amount of capital (left scale) and jobs (right scale)

Source: fDI markets, Financial Times

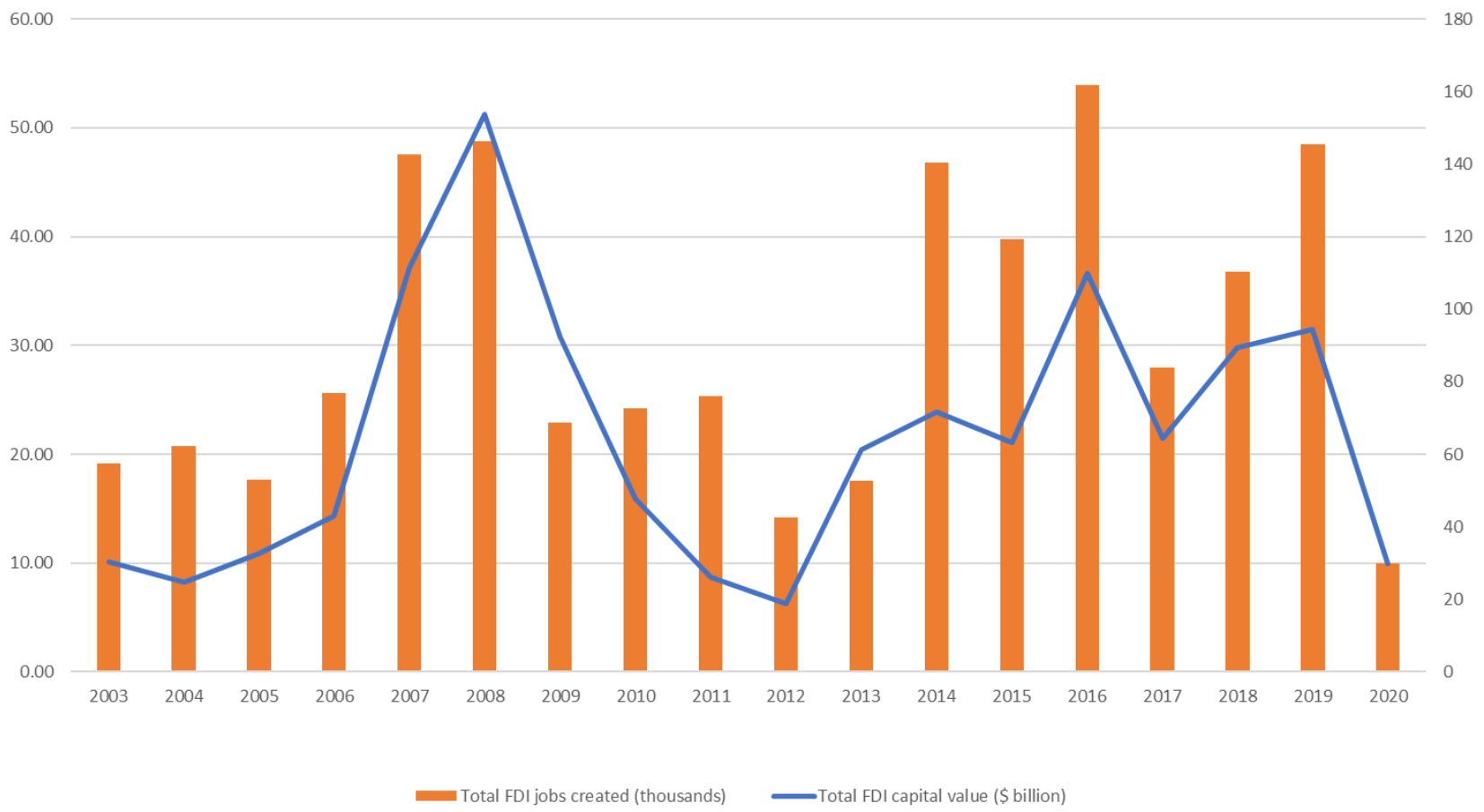

Figure 2.3 Vietnam greenfield FDI capital 2003-2017

Source: Author's calculation from fDi Markets, Financial Times 


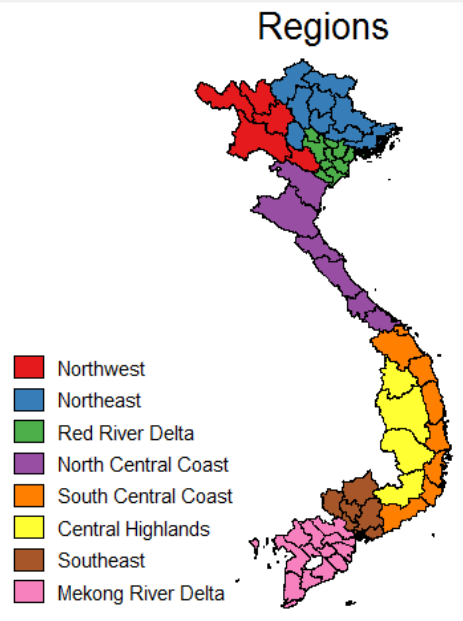

Average growth rate 2003-2015

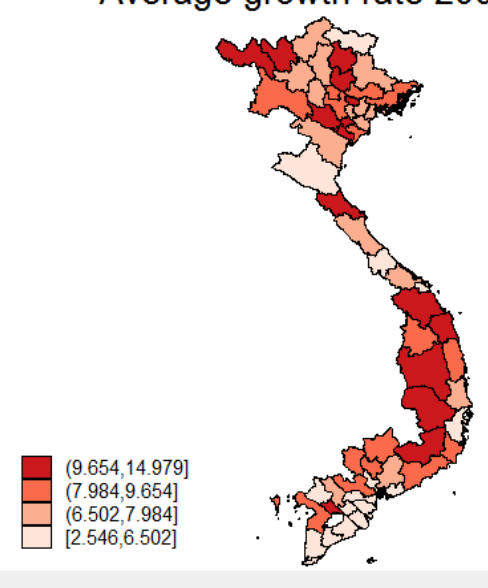

GDP per capita in 2003

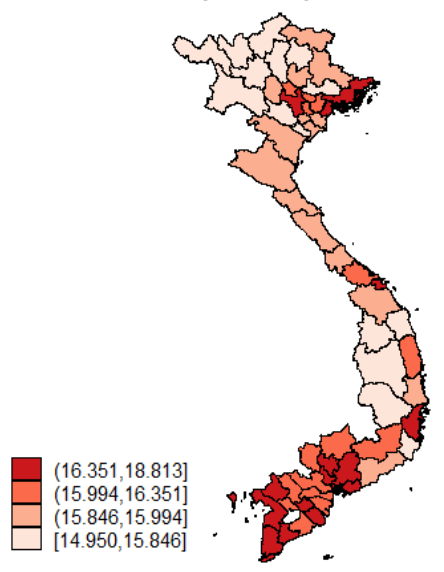

Total FDI capital 2003-2015

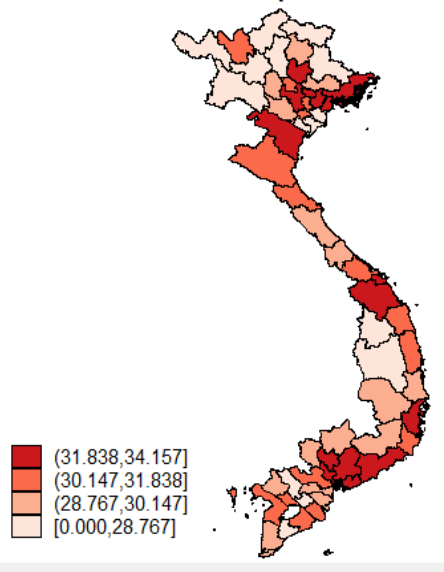

Figure 2.4 Vietnam regional inequality

Source: Author's calculation using GSO and fDi Markets dataset Unit: GDP per capita in log. Average growth rate in \%. Total FDI capital in log 


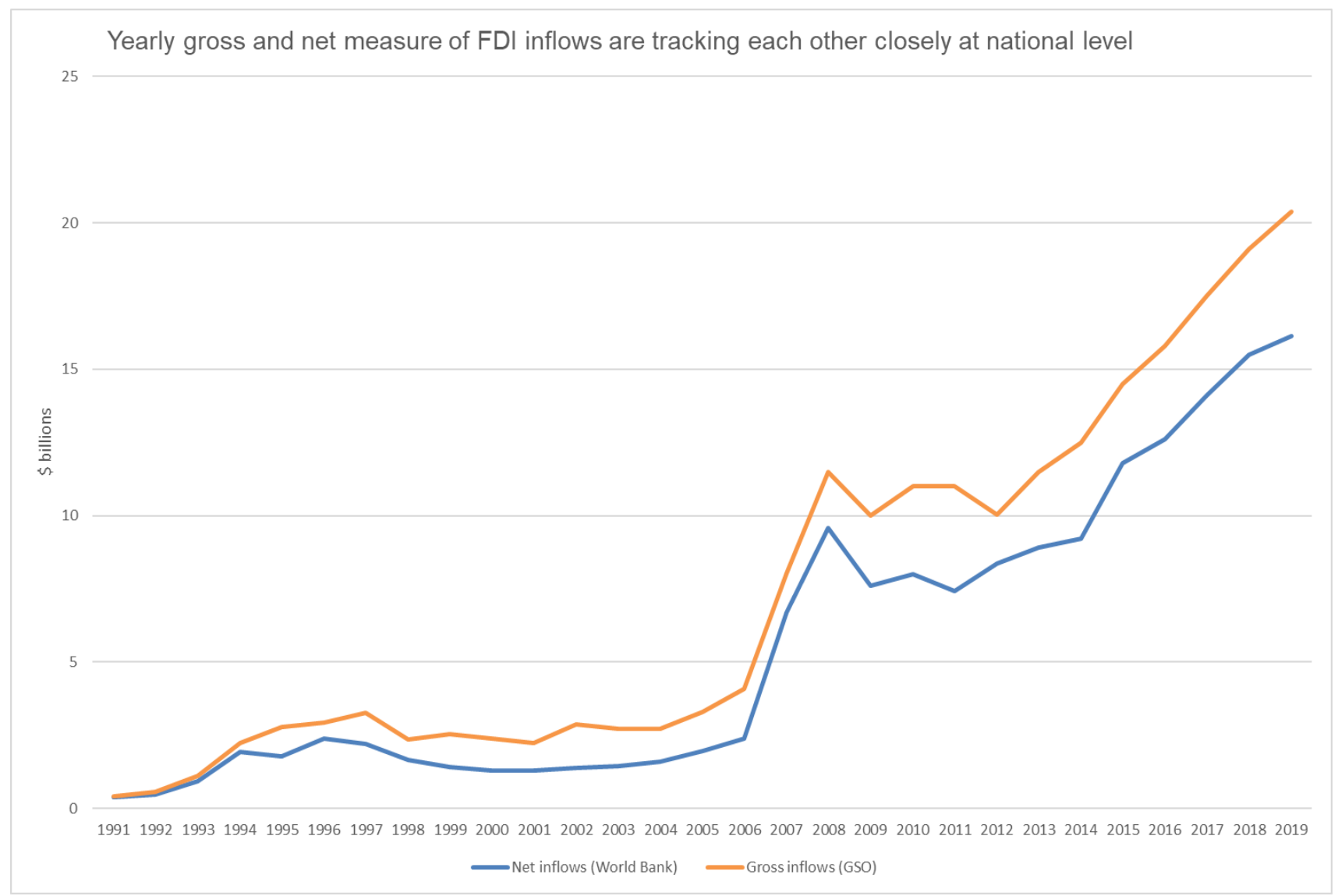

Figure 2.5 Gross and net FDI inflow - national level Source: Author's calculation using World Bank Development Indicator and GSO 


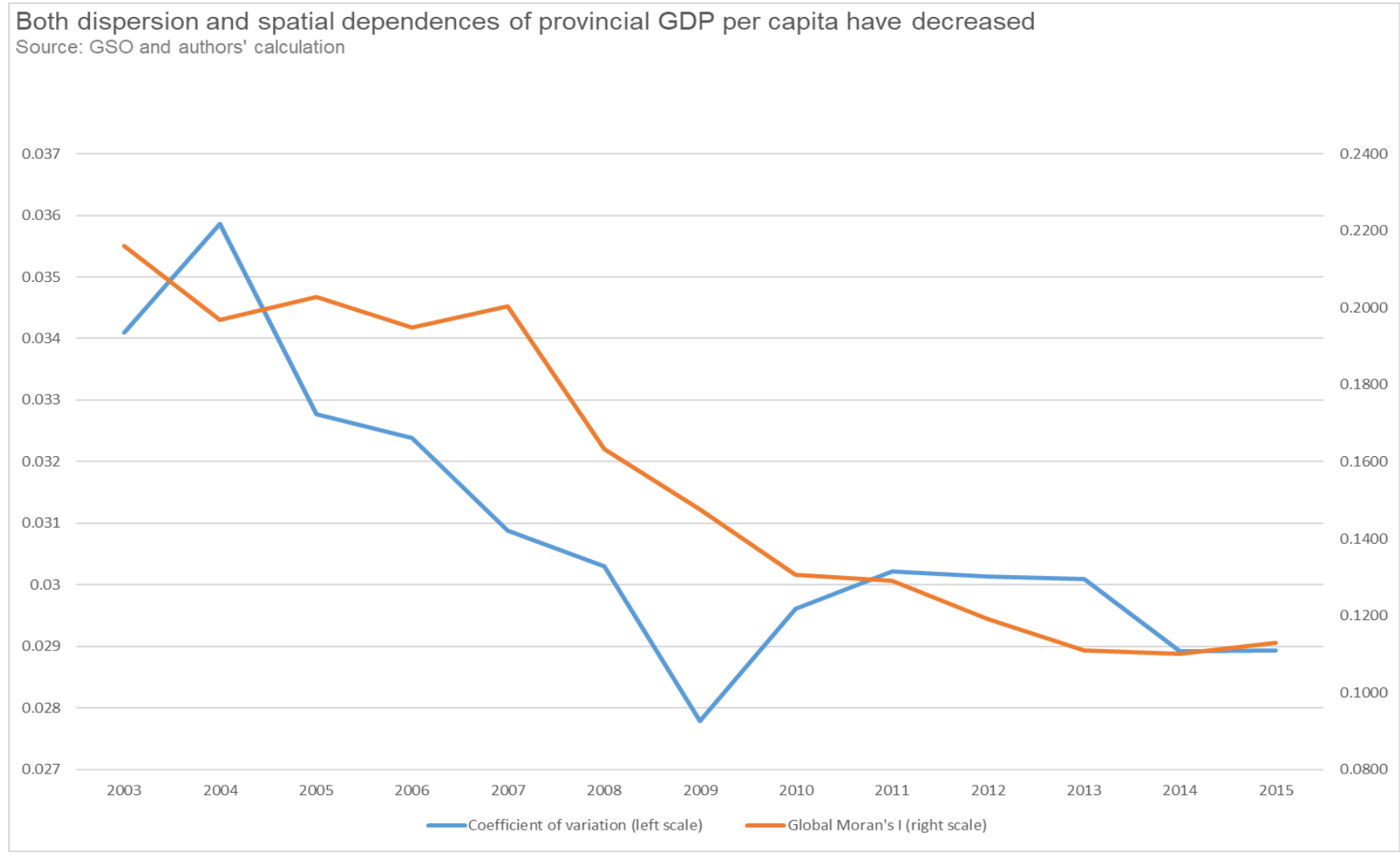

Figure 2.6 Dispersion and spatial dependences among provincial GDP per capita Source: Author's calculation using GSO data 

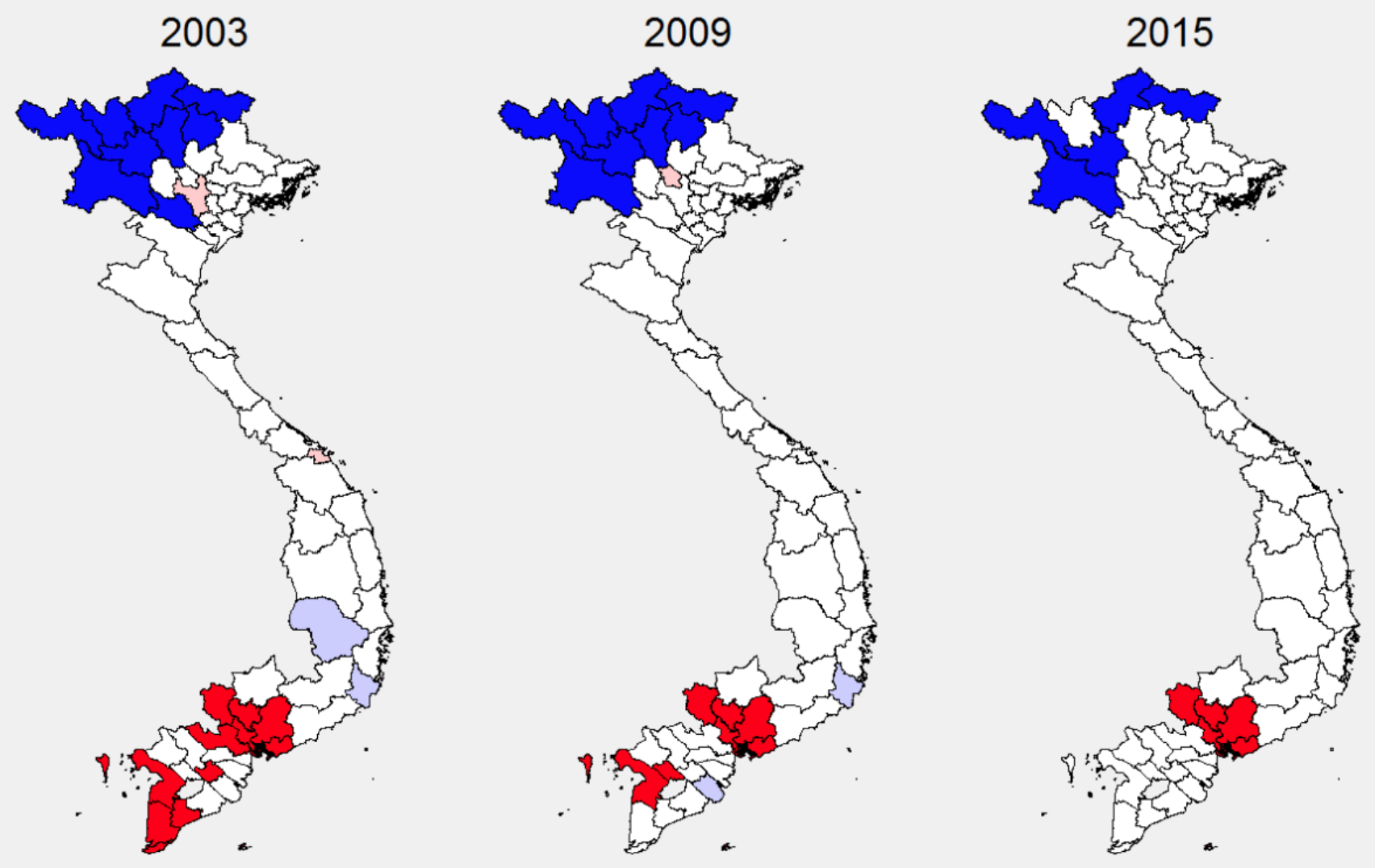

High income - High spatial lag

High income - Low spatial lag

Low income - High spatial lag

Low income - Low spatial lag

Non-significance

Figure 2.7 Moran significance map 

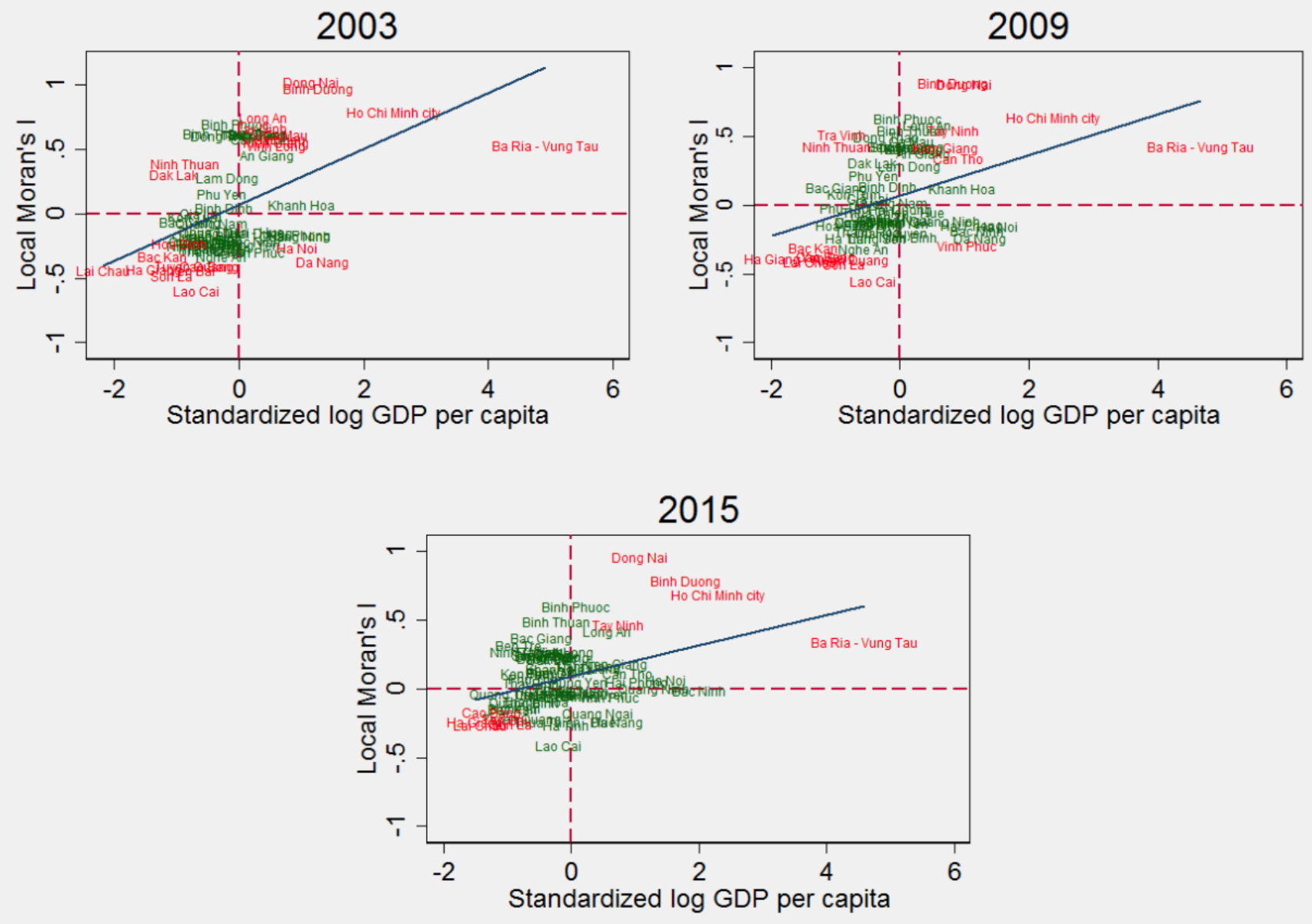

Figure 2.8 Moran scatter plot 
Table 2.1 Global Moran's I statistic from 2003-2015

Global Moran's I statistic

\begin{tabular}{llll} 
& Statistic & Z-score & P-value \\
\hline 2003 & 0.2160 & 6.5514 & 0.0000 \\
2004 & 0.1969 & 6.0621 & 0.0000 \\
2005 & 0.2029 & 6.2982 & 0.0000 \\
2006 & 0.1948 & 6.1054 & 0.0000 \\
2007 & 0.2005 & 6.1353 & 0.0000 \\
2008 & 0.1633 & 5.1222 & 0.0000 \\
2009 & 0.1476 & 4.5373 & 0.0000 \\
2010 & 0.1306 & 4.1591 & 0.0000 \\
2011 & 0.1292 & 4.1700 & 0.0000 \\
2012 & 0.1190 & 3.8668 & 0.0001 \\
2013 & 0.1109 & 3.5729 & 0.0004 \\
2014 & 0.1102 & 3.5388 & 0.0004 \\
2015 & 0.1130 & 3.5705 & 0.0004 \\
\hline
\end{tabular}


Table 2.2 Income convergence and FDI technology levels

Dependent variable: GDP per capita

\begin{tabular}{|c|c|c|c|c|c|c|c|}
\hline & Baseline & Baseline & SAR & SAR & SDM & SAR & SDM \\
\hline Main & (1) & (2) & (3) & (4) & (5) & (6) & (7) \\
\hline \multirow[t]{2}{*}{ Lag GDP per capita } & 0.89483 & .89353 & .88151 & .87987 & .88855 & .88508 & .88626 \\
\hline & $(.05844)^{* * *}$ & $(.05809)^{* * *}$ & $(.05903)^{* * *}$ & $(.05862)^{* * *}$ & $(.05643) * * *$ & $(.05905)^{* * *}$ & $(.05670)^{* * *}$ \\
\hline \multirow[t]{2}{*}{ Lag FDI } & & .00047 & & .00048 & .00060 & & \\
\hline & & $(.00025)^{*}$ & & $(.00024)^{* *}$ & $(.00027)^{* *}$ & & \\
\hline \multirow[t]{2}{*}{ Lag High tech FDI } & & & & & & .00084 & .00097 \\
\hline & & & & & & $(.00025)^{* * *}$ & $(.00026)^{* * *}$ \\
\hline \multirow[t]{2}{*}{ Lag Low tech FDI } & & & & & & .00003 & .00005 \\
\hline & & & & & & $(.00024)$ & $(.00024)$ \\
\hline \multirow[t]{2}{*}{ Population growth } & -.14788 & -.14882 & -.15691 & -.15330 & -.15765 & -.15538 & -.15585 \\
\hline & $(.05394) * * *$ & $(.05407)^{* * *}$ & $(.05418)^{* * *}$ & $(.05445)^{* * *}$ & $(.05473)^{* * *}$ & $(.05372)^{* * *}$ & $(.05527)^{* * *}$ \\
\hline \multicolumn{8}{|l|}{ Spatial lag } \\
\hline \multirow[t]{2}{*}{ W x Lag FDI } & & & & & .00516 & & \\
\hline & & & & & $(.00245)^{* *}$ & & \\
\hline \multirow[t]{2}{*}{ W x Lag High tech FDI } & & & & & & & .00417 \\
\hline & & & & & & & $(.00253)^{*}$ \\
\hline \multirow[t]{2}{*}{ W x Lag Low tech FDI } & & & & & & & .00117 \\
\hline & & & & & & & $(.00167)$ \\
\hline \multirow[t]{2}{*}{ W x GDP per capita } & & & .13447 & .14066 & .16763 & .12723 & .08920 \\
\hline & & & $(.06016)^{* *}$ & $(.05992)^{* *}$ & $(.06052)^{* * *}$ & $(.06026)^{* *}$ & $(.05651)$ \\
\hline$\beta$ & -0.10517 & -0.10647 & -0.11849 & -0.12013 & -0.11145 & -0.11492 & -0.11374 \\
\hline Convergence speed & 11.11215 & 11.25754 & 12.61189 & 12.79811 & 11.81644 & 12.20772 & 12.07449 \\
\hline Half life & 6.23774 & 6.15718 & 5.4959 & 5.41601 & 5.86596 & 5.67794 & 5.74059 \\
\hline Observations & 720 & 720 & 720 & 720 & 720 & 720 & 720 \\
\hline Periods & 12 & 12 & 12 & 12 & 12 & 12 & 12 \\
\hline Log likelihood & 839.726 & 839.726 & 841.440 & 843.068 & 845.508 & 843.621 & 846.116 \\
\hline Two-way fixed effects & Yes & Yes & Yes & Yes & Yes & Yes & Yes \\
\hline
\end{tabular}


Table 2.3 Agglomeration motives

\section{Dependent variable: Number of FDI projects}

\begin{tabular}{lcc} 
& $(1)$ & $(2)$ \\
\hline Relative stock of country of origin agglomeration & 2.66017 & 2.20680 \\
Relative stock of activity agglomeration & $(.25755)^{* * *}$ & $(.19297)^{* * *}$ \\
Relative stock of industry agglomeration & 1.29604 & \\
Constant & $(.20610)^{* * *}$ & \\
& & 2.15948 \\
\hline Log likelihood & 1.59760 & $(.19728)^{* * *}$ \\
Number of observations & $(.33910)^{* * *}$ & $(.59760$ \\
Model & -1228.051 & -973.015 \\
Two-way fixed effects & 336 & 336 \\
\hline
\end{tabular}

Note: Standard errors in parentheses. ${ }^{*} \mathrm{p}<.10, * * \mathrm{p}<.05, * * * \mathrm{p}<.01$. Panel Poisson count model is estimated by the maximum likelihood method. Relative stocks are measured by the ratio of total FDI projects within the same industries/activities or countries of origin as the group of FDI firms in year t over the total stock. 
Table 2.4 Income convergence and FDI agglomerations

Dependent variable: GDP per capita

\begin{tabular}{|c|c|c|c|c|c|c|}
\hline & Baseline & SAR & SDM & Baseline & SAR & SDM \\
\hline Main & (1) & (2) & (3) & (4) & (5) & (6) \\
\hline \multirow[t]{2}{*}{ Lag GDP per capita } & .88472 & .87204 & .87689 & .89265 & .87952 & .88219 \\
\hline & $(.05812)^{* * *}$ & $(.05837)^{* * *}$ & $(.05695) * * *$ & $(.05824) * * *$ & $(.05880)^{* * *}$ & $(.05773)^{* * *}$ \\
\hline \multirow[t]{2}{*}{ Lag Origin } & -.00348 & -.00383 & -.00379 & -.00165 & -.00129 & -.00116 \\
\hline & $(.00240)$ & $(.00264)$ & $(.00253)$ & $(.00220)$ & $(.00215)$ & $(.00213)$ \\
\hline \multirow[t]{2}{*}{ Lag Activity } & .01249 & .01199 & .01186 & & & \\
\hline & $(.00534)^{* *}$ & $(.00494)^{* *}$ & $(.00481)^{* *}$ & & & \\
\hline \multirow[t]{2}{*}{ Lag Industry } & & & & .00517 & .00479 & .00470 \\
\hline & & & & $(.00253)^{* *}$ & $(.00217)^{* *}$ & $(.00217)^{* *}$ \\
\hline \multirow[t]{2}{*}{ Population growth } & -.14576 & -.15405 & -.15629 & -.14804 & -.15736 & -.15978 \\
\hline & $(.05311)^{* * *}$ & $(.05408) * * *$ & $(.05245) * * *$ & $(.05372)^{* * *}$ & $(.05441)^{* * *}$ & $(.05418)^{* * *}$ \\
\hline \multicolumn{7}{|l|}{ Spatial lag } \\
\hline \multirow[t]{2}{*}{ W x Lag Origin } & & & -.01038 & & & .00398 \\
\hline & & & $(.01342)$ & & & $(.01819)$ \\
\hline \multirow[t]{2}{*}{ W x Lag Activity } & & & .06899 & & & \\
\hline & & & $(.02641)^{* * *}$ & & & \\
\hline \multirow[t]{2}{*}{ W x Lag Industry } & & & & & & .01451 \\
\hline & & & & & & $(.01125)$ \\
\hline \multirow[t]{2}{*}{ W x GDP per capita } & & .12827 & .07783 & & .13867 & .15002 \\
\hline & & $(.06078)^{* *}$ & $(.05599)$ & & $(.06072)^{* *}$ & $(.05918)^{* *}$ \\
\hline$\beta$ & -0.11528 & -0.12796 & -0.12311 & -0.10735 & -0.12048 & -0.11781 \\
\hline Convergence speed & 12.24841 & 13.69200 & 13.13737 & 11.35607 & 12.83790 & 12.53478 \\
\hline Half life & 5.65908 & 5.06243 & 5.27615 & 6.10376 & 5.39923 & 5.52979 \\
\hline Log likelihood & 843.830 & 846.540 & 851.176 & 840.089 & 843.144 & 843.628 \\
\hline Observations & 720 & 720 & 720 & 720 & 720 & 720 \\
\hline Periods & 12 & 12 & 12 & 12 & 12 & 12 \\
\hline Two-way fixed effects & Yes & Yes & Yes & Yes & Yes & Yes \\
\hline
\end{tabular}

Note: Standard errors in parentheses. ${ }^{*} \mathrm{p}<.10, * * \mathrm{p}<.05, * * * \mathrm{p}<.01$. SAR: Spatial autoregressive model. SDM: Spatial Durbin model. W is the inverse-distance, row-standardized spatial weighting matrix with the cut-off point at $200 \mathrm{~km}$. Coefficients of explanatory variables are recorded in the first block. Coefficients of spatial lag terms are recorded in the second block. Reduced form coefficients are reported for the SAR and SDM specifications. Period of study is 2003-2015. Number of observations corresponds to 60 provinces in Vietnam. Speed of convergences is measured in \% annually. Half-life is measured in years. All models are estimated using the MLE method 
Table 2.5 Current and Prospective FDI and income convergence

Dependent variable: GDP per capita

\begin{tabular}{|c|c|c|}
\hline & \multirow[b]{2}{*}{ SDM } & \multirow[b]{2}{*}{ SDM } \\
\hline & & \\
\hline Main & (1) & (2) \\
\hline \multirow[t]{2}{*}{ Lag GDP per capita } & .88215 & .88030 \\
\hline & $(.05752)^{* * *}$ & $(.05728) * * *$ \\
\hline \multirow[t]{2}{*}{ Lag FDI } & .00060 & .00063 \\
\hline & $(.00026)^{* *}$ & $(.00027)^{* *}$ \\
\hline \multirow[t]{2}{*}{ Current FDI } & .00046 & .00048 \\
\hline & $(.00025)^{*}$ & $(.00025)^{*}$ \\
\hline \multirow[t]{2}{*}{ Prospective FDI } & & .00043 \\
\hline & & $(.00021)^{* *}$ \\
\hline \multirow[t]{2}{*}{ Population growth } & -.15944 & -.15768 \\
\hline & $(.05453)^{* * *}$ & $(.05499) * * *$ \\
\hline \multicolumn{3}{|l|}{ Spatial lag } \\
\hline \multirow[t]{2}{*}{ W x Lag FDI } & .00417 & .00402 \\
\hline & $(.00240)^{*}$ & $(.00253)^{*}$ \\
\hline \multirow[t]{2}{*}{ W x Current FDI } & -.00176 & -.00192 \\
\hline & $(.00272)$ & $(.00278)$ \\
\hline \multirow[t]{2}{*}{ W x Prospective FDI } & & -.00085 \\
\hline & & $(.00174)$ \\
\hline \multirow[t]{2}{*}{ W x GDP per capita } & .14929 & .14467 \\
\hline & $(.05878)^{* *}$ & $(.06133)^{* *}$ \\
\hline$\beta$ & -0.11785 & -0.1197 \\
\hline Convergence speed (\% annually) & 12.53932 & 12.74925 \\
\hline Half-life & 5.52779 & 5.43677 \\
\hline Number of observations & 720 & 720 \\
\hline Number of years & 12 & 12 \\
\hline Two-way fixed effects & Yes & Yes \\
\hline p-value for LM test of autocorrelation of order 1 & & \\
\hline p-value for LM test of autocorrelation of order 2 & & \\
\hline
\end{tabular}

Note: Standard errors in parentheses. ${ }^{*} \mathrm{p}<.10,{ }^{* *} \mathrm{p}<.05, * * * \mathrm{p}<.01$. SAR: Spatial autoregressive model. SDM: Spatial Durbin model. Coefficients of explanatory variables are recorded in the first block. Coefficients of spatial lag terms are recorded in the second block. Reduced form coefficients are reported for the SDM specification. Period of study is 2003-2015. Number of observations corresponds to 60 provinces in Vietnam. Speed of convergences is measured in \% annually. Half-life is measured in years. All models are estimated using the MLE method. Lagrange Multiplier (LM) test for autocorrelation in panel data follows Inoue and Solon (2006) 


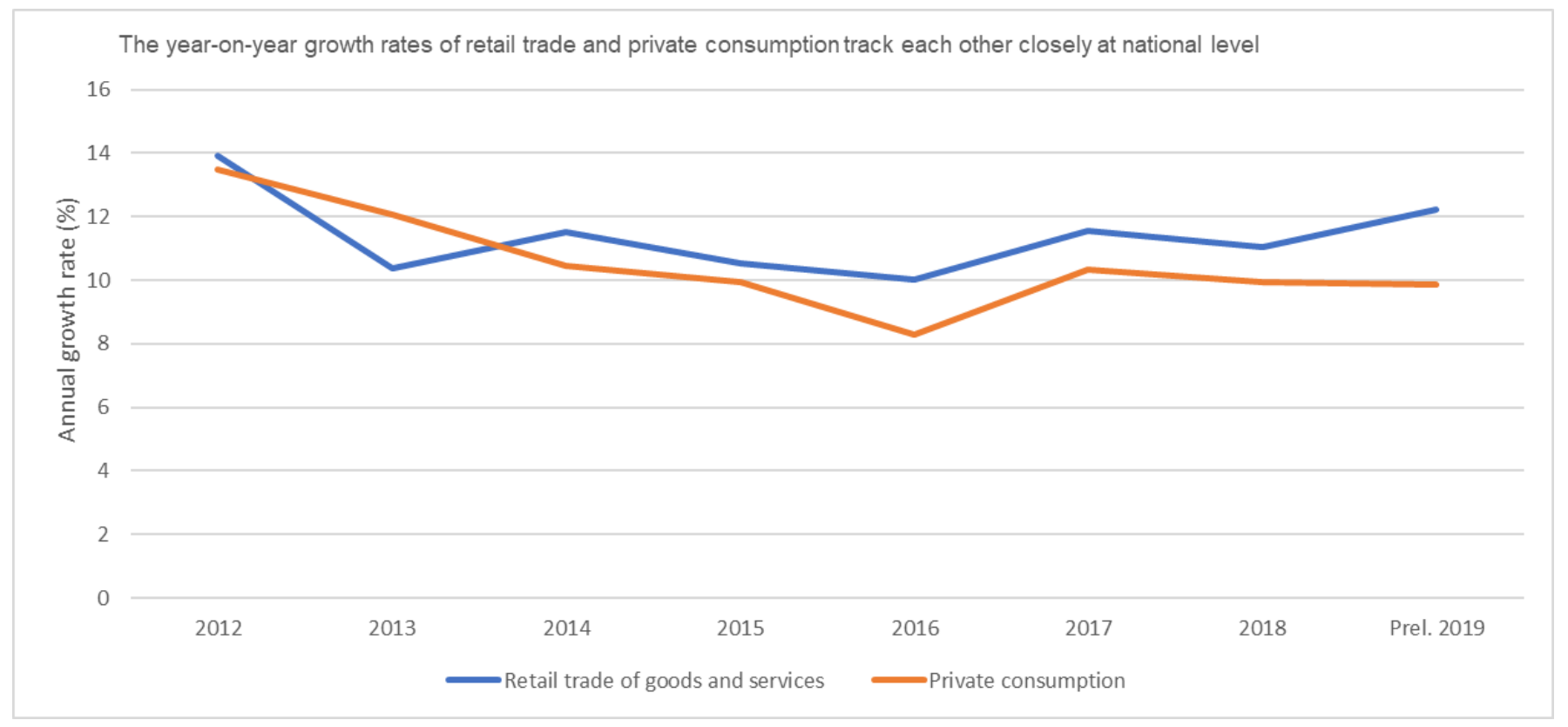

Figure 2.9 Retail trade of goods and services and Private consumption

Source: Author's calculation using World Bank and GSO data 
Table 2.6 Consumption convergence - FDI technology levels

Dependent variable: Consumption per capita

\begin{tabular}{|c|c|c|c|c|}
\hline & SAR & SDM & SAR & SDM \\
\hline Main & (1) & (2) & (3) & (4) \\
\hline \multirow[t]{2}{*}{ Lag Consumption per capita } & .78907 & .79009 & .79344 & .79085 \\
\hline & $(.07762)^{* * *}$ & $(.07743)^{* * *}$ & $(.07819) * * *$ & $(.07779) * * *$ \\
\hline \multirow[t]{2}{*}{ Lag FDI } & .00026 & .00027 & & \\
\hline & $(.00019)$ & $(.00019)$ & & \\
\hline \multirow[t]{2}{*}{ Lag High tech FDI } & & & .00060 & .00058 \\
\hline & & & $(.00031)^{*}$ & $(.00030)^{*}$ \\
\hline \multirow[t]{2}{*}{ Lag Low tech FDI } & & & .00007 & .00007 \\
\hline & & & $(.00020)$ & $(.00020)$ \\
\hline \multirow[t]{2}{*}{ Population growth } & -.15266 & -.15336 & -.15293 & -.15199 \\
\hline & $(.05804) * * *$ & $(.05802)^{* * *}$ & $(.05847)^{* * *}$ & $(.05849) * * *$ \\
\hline \multicolumn{5}{|l|}{ Spatial lag } \\
\hline \multirow[t]{2}{*}{ W x Lag FDI } & -.00000 & .00110 & & \\
\hline & $(.00003)$ & $(.00144)$ & & \\
\hline \multirow[t]{2}{*}{ W x Lag High tech FDI } & & & .00037 & .00000 \\
\hline & & & $(.00147)$ & $(.00006)$ \\
\hline \multirow[t]{2}{*}{ W x Lag Low tech FDI } & & & .00138 & .00000 \\
\hline & & & $(.00103)$ & $(.00002)$ \\
\hline \multirow[t]{2}{*}{ W x Consumption per capita } & -.00263 & .01168 & .01629 & -.00536 \\
\hline & $(.09172)$ & $(.08749)$ & $(.09034)$ & $(.09176)$ \\
\hline$\beta$ & -0.21093 & -0.20991 & -0.20656 & -0.20915 \\
\hline Convergence speed & 23.69002 & 23.56084 & 23.13774 & 23.46470 \\
\hline Half life & 2.92590 & 2.94195 & 2.99574 & 2.95400 \\
\hline Observations & 937.852 & 938.063 & 939.201 & 938.843 \\
\hline Periods & 720 & 720 & 720 & 720 \\
\hline Log likelihood & 12 & 12 & 12 & 12 \\
\hline Two-way fixed effects & Yes & Yes & Yes & Yes \\
\hline
\end{tabular}

Note: Standard errors in parentheses. ${ }^{*} \mathrm{p}<.10, * * \mathrm{p}<.05, * * * \mathrm{p}<.01$. SAR: Spatial autoregressive model. SDM: Spatial Durbin model. Coefficients of explanatory variables are recorded in the first block. Coefficients of spatial lag terms are recorded in the second block. Reduced form coefficients are reported for the SAR and SDM specifications. Period of study is 2003-2015. Number of observations corresponds to 60 provinces in Vietnam. Speed of convergences is measured in \% annually. Half-life is measured in years. All models are estimated using the MLE method. 
Table 2.7 Consumption convergence - FDI agglomerations

Dependent variable: Consumption per capita

\begin{tabular}{|c|c|c|c|c|}
\hline & $\begin{array}{l}\text { SAR } \\
\end{array}$ & SDM & SAR & SDM \\
\hline Main & (1) & (2) & (3) & (4) \\
\hline \multirow[t]{2}{*}{ Lag Consumption per capita } & .78263 & .78545 & .78760 & .78828 \\
\hline & $(.07721)^{* * *}$ & $(.07471)^{* * *}$ & $(.07782)^{* * *}$ & $(.07721)^{* * *}$ \\
\hline \multirow[t]{2}{*}{ Lag Origin } & -.00014 & -.00004 & .00125 & .00134 \\
\hline & $(.00185)$ & $(.00183)$ & $(.00223)$ & $(.00220)$ \\
\hline \multirow[t]{2}{*}{ Lag Activity } & .01004 & .00957 & & \\
\hline & $(.00428)^{* *}$ & $(.00411)^{* *}$ & & \\
\hline \multirow[t]{2}{*}{ Lag Industry } & & & .00272 & .00261 \\
\hline & & & $(.00237)$ & $(.00236)$ \\
\hline \multirow[t]{2}{*}{ Population growth } & -.15075 & -.15507 & -.15234 & -.15365 \\
\hline & $(.05794)^{* * * *}$ & $(.05862) * * *$ & $(.05771)^{* * *}$ & $(.05761)^{* * *}$ \\
\hline \multicolumn{5}{|l|}{ Spatial lag } \\
\hline \multirow[t]{2}{*}{ W x Lag Origin } & .00005 & -.00798 & .00005 & -.00384 \\
\hline & $(.00018)$ & $(.00719)$ & $(.00025)$ & $(.00839)$ \\
\hline \multirow[t]{2}{*}{ W x Lag Activity } & -.00008 & .03755 & & \\
\hline & $(.00099)$ & $(.02200)^{*}$ & & \\
\hline \multirow[t]{2}{*}{ W x Lag Industry } & & & .00004 & .00582 \\
\hline & & & $(.00033)$ & $(.00927)$ \\
\hline \multirow[t]{2}{*}{ W x Consumption per capita } & -.00639 & .02143 & .00233 & .00185 \\
\hline & $(.09309)$ & $(.09716)$ & $(.09117)$ & $(.09078)$ \\
\hline$\beta$ & -0.21737 & -0.21455 & -0.2124 & -0.21172 \\
\hline Convergence speed & 24.50952 & 24.14985 & 23.87649 & 23.79019 \\
\hline Half life & 2.82807 & 2.87019 & 2.90305 & 2.91358 \\
\hline Log likelihood & 942.340 & 944.258 & 938.735 & 938.842 \\
\hline Observations & 720 & 720 & 720 & 720 \\
\hline Periods & 12 & 12 & 12 & 12 \\
\hline Two-way fixed effects & Yes & Yes & Yes & Yes \\
\hline
\end{tabular}

Note: Standard errors in parentheses. $* \mathrm{p}<.10,{ }^{* *} \mathrm{p}<.05,{ }^{* * *} \mathrm{p}<.01$. SAR: Spatial autoregressive model. SDM: Spatial Durbin model. Coefficients of explanatory variables are recorded in the first block. Coefficients of spatial lag terms are recorded in the second block. Reduced form coefficients are reported for the SAR and SDM specifications. Period of study is 2003-2015. Number of observations corresponds to 60 provinces in Vietnam. Speed of convergences is measured in \% annually. Half-life is measured in years. All models are estimated using the MLE method 
Table 2.8 System GMM estimation

Dependent variable: GDP per capita

\begin{tabular}{lcc} 
& \multicolumn{2}{c}{ System GMM } \\
\cline { 2 - 3 } Main & $(1)$ & $(2)$ \\
\hline Lag GDP per capita & 0.913 & 0.8741 \\
Lag High tech FDI & $(.0525)^{* * *}$ & $(.1155)^{* * *}$ \\
& .00063 & .00108 \\
Lag Low tech FDI & $(.00029)^{* *}$ & $(.0003)^{* * *}$ \\
& .00013 & .0002 \\
Spatial lag & $(.00031)$ & $(.00031)$ \\
W x Lag High tech FDI & & \\
& & .0032 \\
W x Lag Low tech FDI & & $(.0020)^{*}$ \\
& & .0015 \\
W x GDP per capita & & $(.0016)$ \\
& & .281 \\
$\beta$ & -0.087 & $(.145)^{*}$ \\
Convergence speed & 9.10194 & -0.1259 \\
Half-life & 7.61538 & 13.45605 \\
Observations & 720 & 5.15119 \\
Periods & 12 & 720 \\
\hline p-value AR(1) & 0.011 & 12 \\
p-value AR(2) & 0.943 & 0.009 \\
p-value Hansen test & 0.419 & 0.673 \\
\hline
\end{tabular}


Table 2.9 Robustness check - FDI technology levels

Dependent variable: GDP per capita

\begin{tabular}{|c|c|c|c|c|c|c|c|c|}
\hline & \multicolumn{4}{|c|}{ Contiguity spatial weights } & \multicolumn{4}{|c|}{ Three-year interval } \\
\hline & SAR & SDM & SAR & SDM & SAR & SDM & SAR & SDM \\
\hline Main & (1) & (2) & (3) & (4) & (5) & (6) & (7) & (8) \\
\hline \multirow[t]{2}{*}{ Lag GDP per capita } & .89174 & .89759 & .89672 & .90359 & .66148 & .62016 & .67176 & .62598 \\
\hline & $(.05898) * * *$ & $(.05696)^{* * *}$ & $(.05933)^{* * *}$ & $(.05581)^{* * *}$ & $(.12720) * * *$ & $(.12655)^{* * *}$ & $(.12964) * * *$ & $(.13116) * * *$ \\
\hline \multirow[t]{2}{*}{ Lag FDI } & .00046 & .00043 & & & .00342 & .00353 & & \\
\hline & $(.00024)^{*}$ & $(.00024)^{*}$ & & & $(.00065) * * *$ & $(.00068) * * *$ & & \\
\hline \multirow[t]{2}{*}{ Lag High tech FDI } & & & .00087 & .00096 & & & .00358 & .00358 \\
\hline & & & $(.00025)^{* * *}$ & $(.00025)^{* * *}$ & & & $(.00089)^{* * *}$ & $(.00091)^{* * *}$ \\
\hline \multirow[t]{2}{*}{ Lag Low tech FDI } & & & -.00001 & -.00003 & & & .00153 & .00159 \\
\hline & & & $(.00024)$ & $(.00024)$ & & & $(.00056)^{* * *}$ & $(.00055)^{* * *}$ \\
\hline \multirow[t]{2}{*}{ Population growth } & -.14397 & -.14487 & -.14683 & -.15060 & -.40099 & -.40015 & -.39915 & -.40345 \\
\hline & $(.05382)^{* * *}$ & $(.05384)^{* * *}$ & $(.05305)^{* * *}$ & $(.05449)^{* * *}$ & $(.11378)^{* * *}$ & $(.10829)^{* * *}$ & $(.11396)^{* * *}$ & $(.11120)^{* * *}$ \\
\hline \multicolumn{9}{|l|}{ Spatial lag } \\
\hline \multirow[t]{2}{*}{ W x Lag FDI } & & .00145 & & & & .00347 & & \\
\hline & & $(.00074)^{*}$ & & & & $(.00067)^{*}$ & & \\
\hline \multirow[t]{2}{*}{ W x Lag High tech FDI } & & & & .00195 & & & & .00275 \\
\hline & & & & $(.00089)^{* *}$ & & & & $(.00562)$ \\
\hline \multirow[t]{2}{*}{ W x Lag Low tech FDI } & & & & .00065 & & & & .00289 \\
\hline & & & & $(.00069)$ & & & & $(.00369)$ \\
\hline \multirow[t]{2}{*}{ W x GDP per capita } & .00328 & .00058 & .00131 & .00691 & .17595 & .18138 & .17569 & .14843 \\
\hline & $(.03760)$ & $(.03704)$ & $(.03716)$ & $(.03606)$ & $(.14420)$ & $(.14697)$ & $(.14658)$ & $(.13598)$ \\
\hline$\beta$ & -0.10826 & -0.10241 & -0.10328 & -0.09641 & -0.33852 & -0.37984 & -0.32824 & -0.37042 \\
\hline Convergence speed (\%) & 11.45807 & 10.80419 & 10.90116 & 10.13796 & 13.77585 & 15.92593 & 13.26180 & 15.42341 \\
\hline Half life & 6.04943 & 6.41554 & 6.35847 & 6.83715 & 5.03161 & 4.35232 & 5.22664 & 4.49412 \\
\hline Number of observations & 720 & 720 & 720 & 720 & 180 & 180 & 180 & 180 \\
\hline Number of periods & 12 & 12 & 12 & 12 & 3 & 3 & 3 & 3 \\
\hline Log likelihood & 840.073 & 842.618 & 840.924 & 843.947 & 202.480 & 202.509 & 205.997 & 206.138 \\
\hline Two-way fixed effects & Yes & Yes & Yes & Yes & Yes & Yes & Yes & Yes \\
\hline
\end{tabular}

Note: Standard errors in parentheses. ${ }^{*} \mathrm{p}<.10, * * \mathrm{p}<.05, * * * \mathrm{p}<.01$. SAR: Spatial autoregressive model. SDM: Spatial Durbin model. Coefficients of explanatory variables are recorded in the first block. Coefficients of spatial lag terms are recorded in the second block. Reduced form coefficients are reported for the SAR and SDM specifications. Period of study is 2003-2015. Number of observations corresponds to 60 provinces in Vietnam. Speed of convergences is measured in \% annually. Half-life is measured in years. All models are estimated using the MLE method. 
Table 2.10 Robustness check - FDI agglomerations

Dependent variable: GDP per capita

\begin{tabular}{|c|c|c|c|c|c|c|c|c|}
\hline \multirow[b]{2}{*}{ Main } & \multicolumn{4}{|c|}{ Contiguity spatial weights } & \multicolumn{4}{|c|}{ Three-year interval } \\
\hline & $\begin{array}{l}\text { SAR } \\
(1)\end{array}$ & $\begin{array}{l}\text { SDM } \\
(2)\end{array}$ & $\begin{array}{c}\text { SAR } \\
(3)\end{array}$ & $\begin{array}{c}\text { SDM } \\
(4)\end{array}$ & $\begin{array}{l}\text { SAR } \\
(5)\end{array}$ & $\begin{array}{l}\text { SDM } \\
(6)\end{array}$ & $\begin{array}{c}\text { SAR } \\
(7)\end{array}$ & $\begin{array}{c}\text { SDM } \\
(8)\end{array}$ \\
\hline Lag GDP per capita & $\begin{array}{c}.87204 \\
(.05837)^{* * *}\end{array}$ & $\begin{array}{c}.87689 \\
(.05695)^{* * *}\end{array}$ & $\begin{array}{c}.87952 \\
(.05880)^{* * *}\end{array}$ & $\begin{array}{c}.88219 \\
(.05773)^{* * *}\end{array}$ & $\begin{array}{c}.59389 \\
(.12182)^{* * *}\end{array}$ & $\begin{array}{c}.66391 \\
(.12798)^{* * * *}\end{array}$ & $\begin{array}{c}.60681 \\
(.13005)^{* * *}\end{array}$ & $\begin{array}{c}.62068 \\
(.13165)^{* * *}\end{array}$ \\
\hline Lag Origin & $\begin{array}{l}-.00391 \\
(.00269)\end{array}$ & $\begin{array}{l}-.00383 \\
(.00262)\end{array}$ & $\begin{array}{l}-.00136 \\
(.00222)\end{array}$ & $\begin{array}{l}-.00164 \\
(.00220)\end{array}$ & $\begin{array}{l}-.01003 \\
(.01480)\end{array}$ & $\begin{array}{l}-.02039 \\
(.01479)\end{array}$ & $\begin{array}{c}.01210 \\
(.01377)\end{array}$ & $\begin{array}{c}.01374 \\
(.01297)\end{array}$ \\
\hline Lag Activity & $\begin{array}{c}.01211 \\
(.00490)^{* *}\end{array}$ & $\begin{array}{c}.00956 \\
(.00455)^{* *}\end{array}$ & & & $\begin{array}{c}.06754 \\
(.02362)^{* * *}\end{array}$ & $\begin{array}{c}.07354 \\
(.02489)^{* * * *}\end{array}$ & & \\
\hline Lag Industry & & & $\begin{array}{c}.00467 \\
(.00222)^{* *}\end{array}$ & $\begin{array}{c}.00402 \\
(.00227)^{*}\end{array}$ & & & $\begin{array}{c}.00884 \\
(.01091)\end{array}$ & $\begin{array}{c}.00953 \\
(.01074)\end{array}$ \\
\hline Population growth & $\begin{array}{c}-.14525 \\
(.05340)^{* * *}\end{array}$ & $\begin{array}{c}-.14609 \\
(.05197)^{* * *}\end{array}$ & $\begin{array}{c}-.14797 \\
(.05380)^{* * *}\end{array}$ & $\begin{array}{c}-.14773 \\
(.05305)^{* * *}\end{array}$ & $\begin{array}{c}-.33661 \\
(.12389)^{* * *}\end{array}$ & $\begin{array}{c}-.33196 \\
(.12315)^{* * * *}\end{array}$ & $\begin{array}{c}-.34725 \\
(.12472)^{* * *}\end{array}$ & $\begin{array}{c}-.38162 \\
(.12766)^{* * *}\end{array}$ \\
\hline Spatial lag & & & & & & & & \\
\hline W x Lag Origin & & $\begin{array}{c}.00060 \\
(.00856)\end{array}$ & & $\begin{array}{c}.00460 \\
(.00815)\end{array}$ & & $\begin{array}{c}-.21223 \\
(.09204)^{* *}\end{array}$ & & $\begin{array}{c}.05214 \\
(.08424)\end{array}$ \\
\hline W x Lag Activity & & $\begin{array}{c}.02043 \\
(.00984)^{* *}\end{array}$ & & & & $\begin{array}{c}.44273 \\
(.14615)^{* * *}\end{array}$ & & \\
\hline W x Lag Industry & & & & $\begin{array}{c}.00518 \\
(.00480)\end{array}$ & & & & $\begin{array}{c}.05421 \\
(.05708)\end{array}$ \\
\hline W x GDP per capita & $\begin{array}{l}-.00380 \\
(.03892)\end{array}$ & $\begin{array}{c}.01754 \\
(.03834)\end{array}$ & $\begin{array}{l}-.00163 \\
(.03848)\end{array}$ & $\begin{array}{c}.00258 \\
(.03821)\end{array}$ & $\begin{array}{c}.12294 \\
(.15281)\end{array}$ & $\begin{array}{c}.07090 \\
(.15823)\end{array}$ & $\begin{array}{c}.12563 \\
(.15122)\end{array}$ & $\begin{array}{c}.09004 \\
(.15800)\end{array}$ \\
\hline$\beta$ & -0.12796 & -0.12311 & -0.12048 & -0.11781 & -0.40611 & -0.33609 & -0.39319 & -0.37932 \\
\hline Convergence speed & 13.69200 & 13.13737 & 12.83790 & 12.53478 & 17.36871 & 13.65362 & 16.65132 & 15.89799 \\
\hline Half life & 5.06243 & 5.27615 & 5.39923 & 5.52979 & 3.99078 & 5.07665 & 4.16272 & 4.35997 \\
\hline $\begin{array}{l}\text { Number of } \\
\text { observations }\end{array}$ & 843.660 & 848.502 & 840.118 & 841.761 & 180 & 180 & 180 & 180 \\
\hline Number of periods & 720 & 720 & 720 & 720 & 3 & 3 & 3 & 3 \\
\hline Log likelihood & 12 & 12 & 12 & 12 & 201.893 & 205.177 & 197.285 & 198.160 \\
\hline Two-way fixed effects & Yes & Yes & Yes & Yes & Yes & Yes & Yes & Yes \\
\hline
\end{tabular}

Note: Standard errors in parentheses. $\$ * \mathrm{p}<.10, * * \mathrm{p}<.05, * * * \mathrm{p}<.01 \$$. SAR: Spatial autoregressive model. SDM: Spatial Durbin model. Coefficients of explanatory variables are recorded in the first block. Coefficients of spatial lag terms are recorded in the second block. Reduced form coefficients are reported for the SAR and SDM specifications. Period of study is 2003-2015. Number of observations corresponds to 60 provinces in Vietnam. Speed of convergences is measured in \% annually. Half-life is measured in years. All models are estimated using the MLE method. 


\title{
Appendix
}

\section{Indicators of High-tech industry and Knowledge-intensive services}

\author{
Sources: Eurostat (2014)
}

\begin{tabular}{|c|c|c|}
\hline $\begin{array}{l}\text { Manufacturing } \\
\text { Industries }\end{array}$ & NACE Re & 2 codes - 2-digit level \\
\hline High-technology & $\begin{array}{l}21 \\
26\end{array}$ & $\begin{array}{l}\text { Manufacture of basic pharmaceutical products and pharmaceutical preparations; } \\
\text { Manufacture of computer, electronic and optical products }\end{array}$ \\
\hline $\begin{array}{l}\text { Medium-high- } \\
\text { technology }\end{array}$ & 27 to 30 & $\begin{array}{l}\text { Manufacture of chemicals and chemical products; } \\
\text { Manufacture of electrical equipment; Manufacture of machinery and equipment n.e.c. : } \\
\text { Manufacture of motor vehicles, trailers and semi-trailers; Manufacture of other transport } \\
\text { equipment }\end{array}$ \\
\hline $\begin{array}{l}\text { Medium-low- } \\
\text { technology }\end{array}$ & 22 to 25 & $\begin{array}{l}\text { Manufacture of coke and refined petroleum products; } \\
\text { Manufacture of rubber and plastic products; Manufacture of other non-metallic mineral } \\
\text { products; Manufacture of basic metals; Manufacture of fabricated metals products, excepts } \\
\text { machinery and equipment; } \\
\text { Repair and installation of machinery and equipment }\end{array}$ \\
\hline Low technology & 31 to 32 & $\begin{array}{l}\text { Manufacture of food products, beverages, tobacco products, textile, wearing apparel, leather } \\
\text { and related products, wood and of products of wood, paper and paper products, printing and } \\
\text { reproduction of recorded media; } \\
\text { Manufacture of furniture; Other manufacturing }\end{array}$ \\
\hline
\end{tabular}

\begin{tabular}{|c|c|c|}
\hline $\begin{array}{l}\text { Knowledge based } \\
\text { services }\end{array}$ & NACE R: & 2 codes - 2-digit level \\
\hline $\begin{array}{l}\text { Knowledge- } \\
\text { intensive services } \\
\text { (KIS) }\end{array}$ & $\begin{array}{r}78 \\
80 \\
84 \text { to } 93\end{array}$ & $\begin{array}{l}\text { Water transport; Air transport; } \\
\text { Publishine activities; Motion picture, video and television programme production, sound } \\
\text { recording and music publish activities; Programming and broadcasting activities; } \\
\text { Telecommunications; computer programming, consultancy and related activities; Information } \\
\text { service activities (section J); } \\
\text { Financial and insurance activities (section K); } \\
\text { Legal and accounting activities; Activities of head offices, management consultancy activities; } \\
\text { Architectural and engineering activities, technical testine and analysis; Scientific research and } \\
\text { development, Advertising and market research; Other professional, scientific and technical } \\
\text { activities; Veterinary activities (section M); } \\
\text { Employment activities; } \\
\text { Security and investigation activities; } \\
\text { Public administration and defence, compulsory social security (section O); Education (section } \\
\text { P), Human health and social work activities (section Q); Arts, entertainment and recreation } \\
\text { (section R). }\end{array}$ \\
\hline $\begin{array}{l}\text { Knowledge- } \\
\text { intensive market } \\
\text { services (excluding } \\
\text { high-tech and } \\
\text { financial services) }\end{array}$ & $\begin{array}{r}73 \text { to } 74 \\
78 \\
80\end{array}$ & $\begin{array}{l}\text { Water transport; Air transport; } \\
\text { Legal and accounting activities; Activities of head offices, management consultancy activities; } \\
\text { Architectural and engineering activities, technical testing and analysis; } \\
\text { Advertising and market research; Other professional, scientific and technical activities; } \\
\text { Employment activities; } \\
\text { Security and investigation activities; }\end{array}$ \\
\hline $\begin{array}{l}\text { High-tech } \\
\text { knowledge- } \\
\text { intensive services }\end{array}$ & 59 to 63 & $\begin{array}{l}\text { Motion picture, video and television programme production, sound recording and music } \\
\text { publish activities; Programming and broadcasting activities; Telecommunications; computer } \\
\text { programmine, consultancy and related activities; Information service activities; } \\
\text { Scientific research and development; }\end{array}$ \\
\hline $\begin{array}{l}\text { Knowledge- } \\
\text { intensive financial } \\
\text { services }\end{array}$ & 64 to 66 & Financial and insurance activities (section $\mathrm{K}$ ). \\
\hline $\begin{array}{l}\text { Other knowledge- } \\
\text { intensive services }\end{array}$ & $\begin{array}{r}58 \\
75 \\
84 \text { to } 93\end{array}$ & $\begin{array}{l}\text { Publishing activities; } \\
\text { Veterinary activities; } \\
\text { Public administration and defence, compulsory social security (section O); Education (section } \\
\text { P), Human health and social work activities (section Q); Arts, entertainment and recreation } \\
\text { (section R). }\end{array}$ \\
\hline
\end{tabular}




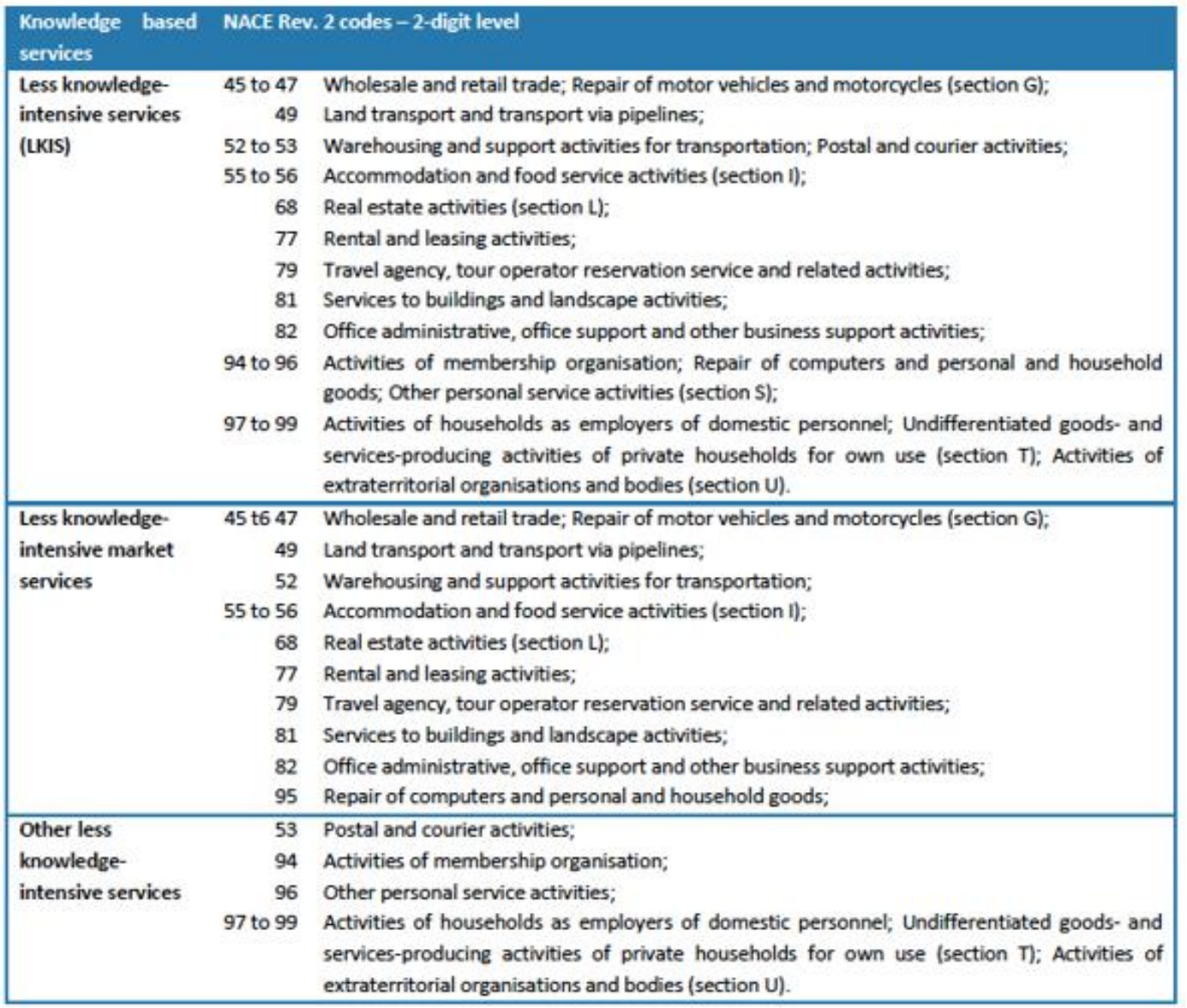




\title{
Chapter 3 FDI inflows and wage inequality: Evidence from Vietnamese labour market post-WTO access
}

\begin{abstract}
This chapter investigates the impact of labour demand shock from foreign multinational firms on local labour market outcomes. Using micro-level data from the quarterly Vietnam Household Labour Force Survey and industry-share Bartik instrument to correct for the endogeneity of FDI locations, we argue that surges in foreign hiring lead to an increase in average provincial wage level through the demand side of the labour market. Moreover, we also show that new employment opportunities from FDI inflows also help reducing provincial wage inequality and raising worker's welfare through benefiting those who have less than tertiary degrees and work in low and mediumskilled jobs considerably more. Our results provide strong support for the local and central government to use FDI attraction as a key policy to achieve the dual benefit of economic growth and raising household living standards.
\end{abstract}




\subsection{Introduction}

Attracting foreign direct investment (FDI) has always been important in the policy agenda of developing countries. It has been widely accepted in the literature that together with international trade, FDI can bring host countries new technologies, financial capital, and employment opportunities required for improving productivity and sustaining economic growth. However, the question of how the benefits of welcoming FDI firms, mainly through their impacts on local labour market demand, are shared among individuals and households is more debatable. Answering this question would require looking beyond aggregate measures like GDP and GDP per capita and examine the micro-level measures of wage and other employment outcomes. Previous theoretical and empirical studies have not been able to reach a consensus on what is the impact of FDI on wage inequality (as summarized in Lipsey, 2004). Moreover, it is also possible that the impact of FDI on wage and living standards is not the same for everyone. Instead, it may depend on industries and workers' human capital endowment including educational and skill level (Hale and Xu, 2016). In this paper, we investigate this effect using data from the Vietnamese Household Labour Force Survey, which contains a rich set of individual demographics and job-related variables. As a result, we are able to not only quantify the aggregate effect but also measure the degree of heterogeneity. Vietnam presents an interesting case for analysis. Since the 1986 Doi Moi reform, Vietnam has continuously increased its openness to international trade and foreign capital flow through relaxing investment regulations, becoming members of many bilateral and multilateral trade agreements, and downsizing the state-owned sector (McCaig and Pavcnik, 2013). Moreover, according to Deloitte's (2016) Manufacturing Competitiveness Report, Vietnam possesses significant comparative advantages in attracting foreign investment thanks to its strategic geographical location, political stability, accessibility by ports, and especially its abundant, dynamic, young, and low-cost labour force. Since the issuant of the first Investment Law in 1987, which set out a basic legal framework for attracting foreign investors, both registered and implemented foreign capital has increased massively (Figure 3.1) ${ }^{25}$. Moreover, from 2008-2009, Vietnam witnessed

\footnotetext{
${ }^{25}$ Note that these official figures are different from the figures calculated using projects' announcement in Chapter 2. Registered capital is defined the amount proposed by potential investors in their plans when seeking for Investment license from the Vietnamese authority while implemented capital is the realization of registered capital.
} 
another considerable jump in foreign capital, largely thanks to the country's accession to WTO in 2008 and the revision of its Foreign Investment Law in 2005, which reduced restrictions on foreign acquisitions, simplified registration procedures, improved access to land and capital, and provided attractive tax incentives for foreign investors.

Over the past 20 years, international trade integration and FDI sector are widely considered as two key drivers of the Vietnam growth model. In terms of the welfare of households and the living standards of workers, several studies have found considerable benefits from export opportunities in Vietnam (Edmonds and Pavcnik, 2005; Seshan 2005; Justino et al 2008; McCaig, 2011). However, FDI's impact beyond GDP and growth is largely unanswered. As FDI becomes more and more important to the country's export value (Figure 3.2), it would be important to determine whether increased employment opportunities from FDI firms have a similar impact as exports on welfare and living standards. Without this, there is a clear possibility that Vietnam would have to participate in a "race-to-the-bottom" in attracting FDI once facing competition from other labourabundant developing countries in the future.

The current Covid-19 pandemic intensifies the need to answer this question, as it appears that the upward trend of FDI is expected to slow-down significantly. While in 2019, Vietnam seemed on track to greatly benefit from the US-China trade tension with 46 new projects and among them 11 relocations from China, the picture for 2020 appeared much gloomier. During the first six months, only 20 FDI greenfield projects were announced, the lowest number since the country opened up to foreign capital. ${ }^{26}$ In the near future, Vietnam would likely need to provide even more incentives to retain its attractiveness to multinational firms. Therefore, it is extremely important to fully understand the impact of FDI on welfare and living standards, in order to determine whether these incentives are justifiable.

In this paper, we attempt to answer this question by analyzing the wage effect of FDI participation in the economy. Generally, FDI can contribute to the wage distribution through direct effects on workers who work in the sector and through spillover effects by raising the demand of labour in general. Specifically, workers in the following local firms and organizations may experience positive effects from a surge in foreign labour demand: (i) Firms that provide intermediate inputs

\footnotetext{
${ }^{26}$ https://www.fdiintelligence.com/article/78397
} 
for FDI's supply chain, (ii) Firms that use FDI products as inputs, (iii) Firms provide supporting services for multinational firms and their workers, including transportation, IT, health, education, and hospitality, etc.

Our identification strategy relies on the variation of FDI employment from 2010 to 2015 in each province and its impact on local wage level. There is potential endogeneity issue with this setup. On the one hand, as labour cost is an important factor in FDI firms' locational decisions, provincial FDI employment and wage level may be negatively correlated. If this is the case, our point estimate will be downwardly biased. On the other hand, there can also be a positive relationship between FDI employment and provincial wage level as FDI firms may choose to locate in big and developed cities where transport and production infrastructure are more developed and skilled workers are easier to find. If this is the case, our point estimate will pick up this spurious positive correlation and be upwardly biased. To correct this endogeneity bias, we utilize a shift-share instrument that uses the interaction between the predetermined local labour market's industry composition in 2007, three years before our period of interest and nationwide annual FDI employment by industry, following Bartik (1991).

Our results show a positive impact of FDI employment on provincial wage level. One percentage point increase in the share of FDI jobs is associated with 1.2 percent increase in average local wage. Looking at the interactions between our variable of interest and some other control variables, we find that the magnitude of positive impact largely depends on workers' characteristics. Within the same industry or sector, the FDI benefits are considerably higher for workers who work in lower-skilled jobs such as elementary occupations, machine operators, and assemblers, or have lower educational attainment such as primary school or under, or work in the informal sector. In terms of the spillover effects by industry, we show that workers who work in professional, administrative and IT are those who reap the most benefits from a surge in FDI employment, compared to those with similar demographics, skill, and educational level working in other industries. In summary, it appears that foreign hiring may decrease overall wage inequality in Vietnam.

The rest of the paper is structured as followed. Section 3.2 reviews some theoretical models and empirical evidence that relate FDI and wage inequality. Section 3.3 provides an overview of our methodology in terms of setting up the regression and constructing our key instrumental variable. 
Section 3.4 presents our main data sources, the Vietnam Household Labour Force survey, and some of our data cleaning decisions. Section 3.5 presents our results and discussions. Section 3.6 concludes and suggests some policy implications.

\subsection{Theoretical framework and literature review}

The theoretical space on the host country's impact of FDI has accelerated recently with a wider focus (Harrison, McLaren, and McMillan, 2011). In this section, we present two simple models that directly link FDI and wage inequality, which is the focus of our paper. These theoretical ideas are by no mean exhaustive, but mainly to serve as a list of possible mechanism which guides any empirical results.

FDI can shift the relative demand towards unskilled workers through offshoring activities. This is the prototype model developed by Feenstra and Hanson (1996) to explain why the traditional Heckscher-Ohlin model failed to capture the increase in inequality in developing countries after opening to trade. The model is later further developed by Zhu and Trefler (2005) and Matsuyama (2007). In this model, a manufacturing good is produced in a competitive industry using a continuum of inputs, each has its own required set of skilled and unskilled workers, or skill intensity, combined with capital. There are two countries, North and South which differ in terms of the relative endowment of skilled versus unskilled workers. With trade openness, inputs can be produced in both countries. However, it is more expensive to produce higher skill-intensity inputs in the South as it has lower skilled to unskilled relative ratio and thus higher skill premium. The reverse case is true for inputs that require lower skill intensity. At equilibrium, there is a deterministic cut-off point that separates the input continuum. With the availability of FDI and other forms of cross-country capital flow, the cut-off changes as the North gradually shifts some production of lower skill-intensity inputs to the South. These inputs, although are the least skilledintensive in the North, now become the most skilled-intensive in the South because of the initial differences in the skill mix between the two countries. As a result, the relative demand for skilled labour raises in the South and consequently induces wage inequality. Vietnam, with the increasing overall contribution of the FDI sector in export value (Figure 3.2), may present a plausible application for this model. More specifically, this model might predict that FDI increases wage inequality in Vietnam. 


\section{Because of the difference in technology, FDI firms can be different than domestic firms in terms}

of the required skill-mix. An illustrative model is proposed by McLaren and Yoo (2017) for the extraction industry. We use their intuition and describe a model for the predominant assembled manufacturing in Vietnam. Considering a small-open Home economy with multiple industries that combining capital and a mix of skilled and unskilled workers to produce goods. Assuming the ratio of skilled versus unskilled workers in Home is predetermined as $L_{d} / L_{u}$ without the presence of FDI. When multinational firms enter the economy and start hiring, they will have a different demand of skilled versus unskilled workers, depending on their products and technologies, says $L_{s}^{F} / L_{u}^{F}$. If $L_{s}^{F} / L_{u}{ }^{F}$ is lower than $L_{s} / L_{u}$, i.e they are hiring disproportionately more unskilled workers compared to domestic firms, the relative demand for unskilled workers will rise and thus the skill premium must fall to restore equilibrium, given that relative supply of skilled versus unskilled workers is inelastic in the short run due to the time it takes for upskilling and retraining. In this case, more FDI employment would reduce wage inequality. This indicative model would apply quite nicely in the manufacturing industry in Vietnam where FDI firms have been involving quite heavily since the opening of the economy (Figure 3.4). Imagine a foreign company with production lines that allow 1 skilled worker to supervise 100 unskilled workers. At the same time, typical domestic firms, without modern production technology, only allow 1 skilled worker to supervise 20 unskilled workers, on average. The appearance of this FDI firm would create an average excess demand of 80 low or unskilled jobs. This excess demand would in turn raise the average wage for low-skilled or unskilled workers and induce people to move out of rural, agricultural jobs towards manufacturing. In the case of Vietnam, this theoretical model may predict that FDI decreases wage inequality.

The contrasting conclusion from these two theoretical frameworks above has led to increasing interest in new, more micro-founded models (Harrison, McLaren, and McMillan, 2011) as well as empirical research. From a macro perspective, Jaumotte, Lall, and Papargeorgiou (2013) use crosssectional data on both developing and developed countries to disentangle the impact of skill-biased technological progress, international trade, and international capital flows in the form of FDI on income inequality, measured by the Gini coefficient. They find that while FDI is associated with an increase in income inequality, trade integration tends to have an opposite effect. 
Many other researchers, in fact, argue that the impact of FDI is non-homogenous. Herzer and Nunnenkamp (2011), using panel co-integration techniques to correct for potential endogeneity in European data, concludes that in the short run FDI inflow increases inequality. However, in the long run, this relationship turns negative. Figini and Horg (2011) find a similar result using data on developing countries and FDI stock as the main treatment. The impact on inequality can also vary with the composition of FDI, in which R\&D intensive capital imports may increase skill premium while less knowledge-intensive ones reduce it (Raveh and Reshef, 2016).

Using the instrumental variable approach, Lin, Kim, and Wu (2013) provide strong supporting evidence of a non-linear impact of FDI, conditional on the host countries' human capital level. Only below a certain level, FDI benefits people at the lower end of the income distribution considerably more. However, once the host country surpasses this level, FDI can widen inequality by raising the income of rich people disproportionately more. Absorptive capacity is another characteristic which determines the direction of FDI impact. Wu and Hsu (2012), using various measures of infrastructure quality as proxies, argue that FDI has no impact on inequality in countries with adequate absorptive capacity while may be harmful to those without.

From a micro perspective, previous studies have examined the impact of FDI on wage inequality at three main target levels: firms, industries, and regions/provinces. Lipsey and Sjöholm (2004), using plant-level data from Indonesian manufacturing, find that FDI increases wage rate in foreigninvested firms but the spillover impact, both backward and forward, is limited at best. Similar patterns emerge in Mexico and Venezuela (Aitken, Harrison and Lipsey, 1996).

However, Chen, Ge, and Lai (2011) argue that the presence of multinational firms put downward pressure on domestic firms' wage and thus widens inequality. Taylor and Driffield (2005) use UK industry data to examine how much FDI inflows contribute towards wage inequality relative to skilled-bias technology change and trade integration. They find that on average, 11 percent of wage inequality can be explained by FDI. Previous empirical evidence using geographical level data is mixed. Chintrakarn, Herzer, Nunnenkamp (2012), using panel cointegration techniques and statelevel panel data in the US, suggest that FDI inflow has a considerable impact on reducing income inequality. Ge (2006) finds a similar result with panel data of Chinese cities. However, Hanson (2007), exploiting the large variation in FDI across Mexico states, argues that FDI and globalization raise inequality. Several factors may explain these different conclusions such as the 
period of study, country-specific structural characteristics, or methodological choices including whether to deal with the endogeneity of FDI.

Research on the impact of globalization on household welfare using intra-national variation is also relevant to our study. Topalova (2011), using Indian data during the trade liberalization period, finds that poverty rate increases in more exposed districts. Kovak (2013) confirms a similar impact of trade openness on local wages in Brazil. In contrast, Chiquiar (2008), through examining the variation in regional exposure to NAFTA in Mexico, suggests that that globalization can decrease skill premium and raise the relative wage of unskilled workers. McCaig (2011), using provincial variation in industry structure and corresponding exposure to trade shocks from the 2011 USVietnam Bilateral Trade Agreement, provides strong supporting evidence that globalization can reduce both poverty and inequality by disproportionately benefit workers with lower educational levels.

Apart from the McCaig's (2011) paper above, there are two other studies on Vietnam that are closely related to our research question. Firstly, McLaren and Yoo (2017), using measures of household welfare from Census data, suggest a decline in living standards for households that did not have members working for FDI firms and a small gain for households with members who are FDI employees. Secondly, Bui et al (2019) examine the impact of foreign firm revenue at provincial level on welfare outcomes of individuals and households. They find the increasing presence of FDI firms leads to lower poverty rates and higher household expenditure levels. However, the impact at the individual level is modest at best.

Our study differs from previous studies on the impact of FDI inflow and trade on inequality in Vietnam in three ways. First of all, wage data from the Household Labour Force Survey allows us to use a direct and accurate measure of individual welfare instead of the indirect, household-level proxy such as access to water or electricity as in McLaren and Yoo (2017). Secondly, with rich demographics and job-related dataset from the Survey, we can examine how labour demand shocks from foreign firms affect wage inequality through simple interaction variables. Thirdly, we believe that the modest impact on wage found in Bui et al (2019) is only a result of the downward bias caused by the endogeneity of FDI. Therefore, our proposed utilization of the Bartik instrument would be a better option. Moreover, without further information on the contribution of labour cost 
to FDI firms' total cost, the number of jobs created would be a better alternative than revenue to measure the extent of positive labour demand shock from foreign hiring.

\subsection{Methodology}

We begin by estimating the baseline model as follows

$$
W_{i j t}=\alpha+\beta_{1} * F D I_{j t}+\beta_{2} * X_{i j t}+D_{j}+D_{t}+\beta_{3} * S C O L I_{t}+\varepsilon_{i j t}
$$

where:

$W_{i j t}$ is the log of the real wage (deflated using national consumer price index) of worker $i$ in province $j$ at year $t$

$F D I_{j t}$ is the number of FDI-created jobs in province $j$ at year $\mathrm{t}$, standardized by provincial population in $2007 .^{27}$

$X$ is a set of individual characteristics, including sex, age and age squared, marital status, urban/rural dummy, occupation (low-skilled, medium-skilled, high-skilled, following ILO occupational level), the formality of jobs (working for registered businesses and/or having social insurance), the education level (primary or under, lower secondary, upper secondary, tertiary or higher), industry, and job security (temporary or permanent contract), following the Mincerian earning equation (Mincer, 1958).

$D_{j}$ and $D_{t}$ are province fixed effects for 63 administrative provinces and year fixed effects for our period of study 2010-2015.

$S C O L I_{j t}$ is the logarithm of the spatial cost of living index (with Hanoi $=100$ ) of province $j$ at year $t$, to account for price differences among provinces.

Even though our treatment is at provincial level, we utilize an individual-level regression. There are two reasons for this set-up. Firstly, it allows us to factor out any variation in wage that can be explained by individual characteristics. Secondly, even though it is numerically similar to a provincial-level regression of average wage level and FDI employment, our approach allows us to

\footnotetext{
${ }^{27}$ We choose this approach instead of standardizing by current year's population to factor out the impact of annual population growth on wage inequality, while at the same time accounting for differences in provinces' size.
} 
explore the heterogeneity of impacts by workers' characteristics using simple interaction variables. One potential issue with this setup is the correlations between the unobservable errors for individual observations within a province. Specifically, in our model, this correlation is perfectly positive as workers within one province face the same surge or drop in FDI employment. According to Bertrand, Duflo, and Mullainathan (2004), failing to account for this may inflate the p-value and produce overly optimistic significant results. Therefore, we follow their suggestions and cluster our standard errors at provincial level.

The potential endogeneity between FDI employment and provincial wage level bias may create spurious negative or positive correlation and thus lead to bias and inconsistency in our main variable of interest. To correct for this, we create a Bartik-type, or shift-share instrument to provide exogenous variation:

Shift-share instrument: $F D I_{-} I V_{j t}=\sum_{k} \theta_{j}^{k} * F D I_{-} j o b s_{t}^{k}$

where:

$\theta_{j}^{k}$ is the share of industry $k$ 's total jobs that located in province $j$ in 2007, before the surge in FDI (the share)

$F D I_{-} j o b s_{t}^{k}$ is the number of FDI jobs in industry $k$ in year $t$ (the shift)

Our estimation depends on the exclusion restrictions and validity of the instrument. First of all, we argue that our instrument is exogenous to any local labour market demand shock after 2007. Moreover, it should also highly correlated with our main variable of interest as multinational firms will prefer to hire, other things equal, in locations where that firm's industry has already been established. To provide further robustness, we use another set of Bartik instruments based on occupational share instead of industry share, both on its own and together. Similar logic applies as FDI firms may choose to locate where they can have access to a pool of workers whose skillsets are more compatible with their productions. All instruments are standardized by the provincial population in 2007 for consistency. ${ }^{28}$

\footnotetext{
${ }^{28}$ We acknowledge that doing so may create some spurious correlation between our endogenous variable and the instruments. However, any other form of standardization would face similar issue.
} 


\subsection{Data}

\subsubsection{Data sources and variables construction}

We use data from the Vietnam Household Labour Force Survey (HLFS) from 2010 to 2015 to conduct our analysis. To construct the Bartik instrument, we also use HLFS data in 2007. The HLFS is run every quarter by the General Statistics Office (GSO) using a 15 percent random sampling of the nearest Population and Housing Census. It is mainly used to collect labour market activity and outcome of household members to produce official statistics. Survey designs and variables definitions follow the International Labour Organization (ILO)'s standards. Respondents are sampled to ensure the aggregate quarterly and annual data is representative at regional and provincial level, respectively. Individual data collected from the survey include demographic variables such as age, sex, marital status, etc as well as labour market information such as sector, industry, earnings, hours of work, etc. Because of data limitations regarding self-employment and agricultural income, we only use a subsample of wage workers who are between 16 and 65-yearold at the interview date.

We construct our main variable of interest, provincial FDI employment, using the sector variable which indicates whether an individual is working for a foreign-invested firm. We also appropriately weight our calculation using the sampling weights provided in the survey data ${ }^{29}$ The main outcome variable, logarithm of wage, is calculated by monthly earnings divided by four times the usual weekly hours of work. To ensure comparability over time, we deflate the wage using national CPI. To account for differences in the living cost across provinces, we include the logarithm of spatial living cost index (SCOLI) as an explanatory variable.

Other variables which are not readily available include the formality of jobs and unemployment status. We construct those using the questionnaire's flowchart provided in each survey. For example, an individual is considered working in the formal sector if he or she has social insurance or his/her employer is registered for tax purposes. An individual is considered to be unemployed if he or she is out of jobs but has been actively looking for jobs during the reference period.

${ }^{29}$ These sampling weights are calibrated by the General Statistics Office following ILO standard, based on the probability of being chosen. 


\subsubsection{Summary statistics and exploratory analysis}

Table 3.1 shows some demographics and employment statistics for our sample of wage workers over time. The percentage of wage worker in the labour force has increased steadily from 35 percent in 2010 to nearly 42 percent in 2015. Inflation-adjusted monthly earnings and hourly wages maintained their growth rates year on year except for 2015. The private and foreign-invested sectors provided increasing number of wage-paying jobs while the public sector shrank in size. ${ }^{30}$ The number of workers who work in medium-skilled jobs or have tertiary degree has increased over the period, although the annual growth rates have been inconsistent. Most wage-paying jobs are created in the services industry, but the manufacturing sector is becoming more and more important.

Figure 3.3 presents the distribution of FDI jobs across provinces, standardized by population. Most of the foreign hiring is concentrated in three main hubs: the Mekong River Delta - North East, Central Coast, and South East. However, apart from big cities like Hanoi, Da Nang or Ho Chi Minh city, many other provinces within these regions also emerge as major destinations for FDI firms, including Thai Nguyen, Bac Ninh (in the North East region), Quang Nam (in the Central Coast region) or Long An, Dong Nai and Tay Ninh (in the South East region). This may signal a movement of FDI firms to take advantage of more competitive wage rates and abundant labour force. Figure 3.4 shows the distribution of FDI jobs by industry over time. While FDI in manufacturing has been consistently providing large employment opportunities, construction, mining and quarrying, and agriculture are becoming more prominent.

For preliminary analysis regarding the potential relationship between FDI hiring and wage inequality, we compare the trends of total number of FDI jobs and national wage Gini coefficients from 2010 to 2015 (Figure 3.5). Overall, no significant pattern emerges. This may be because the distribution of FDI jobs is relatively uneven among provinces, thus any relationship at a national level is obscured. However, when we examine this relationship at provincial level (Figure 3.6), there appears to be a negative association between the increasing presence of FDI firms and local wage inequality. This simple correlation from pooled observations is by no means strong supporting evidence for the true causal relationship between FDI and inequality as we have not

\footnotetext{
${ }^{30}$ These trends reflected recent Vietnamese government's effort to downsize the state-owned sector (McCaig and Pavcnik, 2013).
} 
considered unobservable provincial characteristics or the endogeneity of FDI. However, it does motivate our detailed analysis in the next section.

\subsection{Results}

\subsubsection{Baseline model - OLS}

In this section, we present our baseline results using the OLS model for Vietnamese wage workers from 2010-2015 (Table 3.2). The main dependent variable is the logarithm of individual hourly wage rate. The explanatory variables include the share of FDI employment in each province, and demographic variables such as sex, age, age squared, marital status, urban/rural, and education level. Provincial and time fixed effects are also included to capture any time-invariant heterogeneity and common temporal shock to all provinces. To test the robustness of our results, we further control for other job-related dummy variables including sector, the formality of jobs, occupational level, industry, and contract type by subsequently including them in our model.

In Model 1, our variable of interest, provincial FDI employment is positive and strongly significant at 1 percent level. The size of the estimated coefficient implies that 1 percentage point increase in the standardized FDI employment is associated with approximately 1.14 percent increase in the average individual wage level, ceteris paribus. The demographics control variables appear to be robust and show expect signs. Among them, the sex dummy variable suggests that female workers' wages are 14 percent less than their male counterparts, on average. The negative age-squared and positive age point towards an inverse U-shape relationship between wage and experience (as proxied by age). Married and urban workers earn around 6.4 and 7.9 percent more than single and rural workers, respectively. In terms of the return to education, compared with workers who finish primary school or lower, workers with lower secondary, upper secondary, and tertiary or higher qualifications $^{31}$ earn 9.6, 27.3, and 69 percent more. These differences are consistent with the conventional rate of return to education in Vietnam of around 9 percent per additional year of schooling (World Bank, 2018). ${ }^{32}$ The R-squared suggests that FDI employment and individual demographics characteristics can explain around 35.7 percent of the variation in wage level.

\footnotetext{
${ }^{31}$ Workers with vocational qualifications are also included in the equivalent group according to the Vietnam National Qualification Framework (NQF).

${ }^{32}$ http://documents1.worldbank.org/curated/en/115641545141262780/pdf/WPS8679.pdf
} 
The additions of job-related dummy control variables in Model 2 to 6 slightly decrease the estimated magnitude of our main variable. However, its sign and significance remain largely robust. In the most expansive model, Model 6, 1 percentage point increase in provincial FDI employment share is associated with approximately 1 percent increase in wage level. The inclusion of these control variables is justified by the improved R-squared across all models. In terms of sector-specific variation, workers in foreign firms and public organizations earn 4.5 and 12.9 percent more than those who work in private firms, respectively. As expected, those with formal jobs, indicated by having social insurance or working for formally registered businesses, are paid 6 percent more. The dummy variables for occupational skill level reinforce the story about the rate of return in education. High-skilled and medium-skilled workers, as defined by ILO standard, have on average 9 and 32 percent higher wage rates than low-skilled workers. Among 19 industry dummies, the estimated coefficients are the highest for construction; financial intermediation, banking, and insurance; real estate services; and mining and quarrying while the lowest are the communist party and political - social organization's activities, public administration and defense, education and training, and hotel and restaurants. ${ }^{33}$ In terms of the impact of job security, workers with permanent contracts are paid 17.2 percent more than those without them.

\subsubsection{Baseline model - IV}

Because of the potential endogeneity problem described in section 3.3, the estimated coefficients of FDI employment can be biased either upward (if FDI firms are more likely to locate in developed cities where wages are generally higher) or downward (if FDI firms choose to hire in provinces with lower average wage to minimizing production cost). Table 3.3 reports the results for our baseline regression with the industry shift-share instrument. We follow the same procedure as in the previous section: estimate our model with a minimal set of classic Mincerian demographic covariates, and then add job-related dummy variables subsequently. As our main variable, FDI employment and its instrument are measured at provincial level, we examine the relevance condition by using the mean value of the control variables in the first stage. The F-statistics for the first stage are around 7 to 8 which suggests that our constructed Bartik instrument is relatively strong. Across all specifications with different sets of control variables, the coefficient of FDI

\footnotetext{
${ }^{33}$ We omit these coefficients from Column 5 - Table 3.2.
} 
employment remains positive and significant, similar to the OLS models. However, all else equals, 1 percentage point increase in FDI firms' local hiring is associated with 1.3-1.5 percent increase in average local wage level, compared with the 1 percent we have found in OLS models. This upward correction of the instrumental variable approach suggests that the negative correlation between multinational firms' hiring and local wage level may be the dominant effect causing endogeneity.

It is important to note that the estimated coefficient of FDI employment above represents the average effect across provinces. However, there is a wide range of variation in foreign hiring both across province and over time. As we estimate our model using the within-province fixed effects model, we interpret our results using the standard deviation of FDI employment in each province over the study period of 2010-2015. In our sample, this statistic ranging from a minimum value of 0.005 percent in Lai Chau to a maximum value of 5.67 percent in Binh Duong. Therefore, one within-province standard deviation increase in local foreign hiring is associated with an increase in the average wage of as small as 0.0075 percent $\left(0.005^{*} 1.4\right)$ in provinces with barely any FDI to as big as 7.9 percent $(5.67 * 1.4)$ in the FDI hubs. To better understand the economic significance of our estimated coefficient, we plot the raise in local wage level from one standard deviation increase in FDI employment in Figure 3.7 - left. Unsurprisingly, the three main FDI locations: Red River Delta (including the capital Hanoi) and South East (including the largest city Ho Chi Minh city), and partially the Central Coast region (including the third-largest city Da Nang) are those who reap the most benefits from increasing FDI employment with an associated increase in local wage level of over 1.5 percent. In Figure 3.7 - middle, we examine how these potential increases compared with the average annual provincial wage growth. Clearly, foreign firms can play significant parts in improving the living standards of workers, accounting for around 10-20 percent of the average wage gains in provinces. However, there appears to be a huge untapped potential in poorer regions including the Northern region, Central Highlands and Mekong River Delta where wage has been growing faster than the rest of the countries - possibly due to diminishing marginal product of labour and convergence effect - but FDI barely plays any role. It suggests that if the foreign firms distribute more evenly across the country, they can be integral in the governments' efforts to bring poorer provinces closer to the richer ones. However, whether this is possible largely depends on the overall infrastructure quality and how easy and fast it is for goods and workers to move from these regions to the FDI hubs or other international connection points. 


\subsubsection{Heterogenous treatment effects}

Even though we have found that FDI employment raises the average local real wage level, currently its impact on inequality is still obscure. In this section, we estimate our baseline model with the additions of some interaction variables to determine whether any group of workers is getting greater benefits from surges in local foreign hiring and the magnitude of these differences. As FDI employment is endogenous, its interaction with any other exogenous control variables is also endogenous. Therefore, we include the product of the Bartik shift-share instrument variable and the control variable of interest as instruments in the first stage. Table 3.4 presents the results. The first row in every column shows the estimated coefficient for the base group. Similar to sections 3.5.1 and 3.5.2, we use the within standard deviation of annual FDI employment to illustrate economic significance. This standard deviation is 0.87 in our sample.

Theoretical frameworks by Feenstra and Hanson (1999) or McLaren and Yoo (2017) mainly rely on the labour force skill mix to explain the impact of FDI and trade on wage inequality. Therefore, in Table 3.4, we interact local foreign hiring with a direct measure of skill level - ILO's occupational scale - and a proxy, indirect measure of skill level - educational attainment. The coefficient of FDI employment represents its association with average wage level for the base group, low-skilled workers, and workers with primary education or under, respectively. Moving down the rows, the interaction variables are negative, significant, and smaller for workers with higher skill levels and educational levels. In terms of workers' occupational skill levels, 1 standard deviation increase in local foreign hiring is associated with 1.41, 1.23, and 1.14 increase in average low-skilled, medium-skilled, and high-skilled wage, respectively. ${ }^{34}$ In terms of educational level, 1 standard deviation in local foreign hiring is associated with 1.44 percent increase in average wage level for workers with primary education and under. These increases drop to only $1.29,1.21$, and 0.76 percent for workers with lower secondary, upper secondary, and at least tertiary degrees, respectively. Our results produce strong and robust evidence that surges in local foreign hiring is more beneficial for lower-skilled workers and therefore can reduce wage inequality. One possible explanation is that the presence of foreign multinational firms has shifted the relative demand for lower-skilled workers and thus wage premium should decrease to restore equilibrium. We investigate the possibility of this mechanism by comparing the employed skill mix between the

\footnotetext{
34 These are computed by $0.87 \times 1.63,0.87 \times(1.63-0.2)$ and $0.87 \times(1.63-0.7)$, respectively
} 
domestic sector (including public organizations) and the foreign sector. Figure 3.8 - upper shows that during our period of interest, FDI firms on average employ around 10 low or medium-skilled workers for every 1 skilled worker. This ratio has been increasing, possibly reflects the expansion of FDI firms' production over time. On the other hand, this number for domestic firms and public organizations is only 4. A similar pattern emerges when we consider the number of workers with no tertiary degree per 1 college-qualified worker (Figure 3.8 - lower). ${ }^{35}$ Therefore, when FDI presence becomes more and more prominent in the local labour market, there will be a shift in demand towards low and medium-skilled workers, and thus wage premium decreases.

Another channel through which FDI employment can impact wage inequality is the spillover effects. It has been well-documented in the literature that multinational firms not only pay higher wage rate but also can raise average wages in local firms through forward and backward industry linkages, and creating excess demand for services (Lipsey and Sjoholm, 2004; Taylor and Driffield, 2005; Kneller and Pisu, 2007; Javorcik, 2014; Lu et al, 2017). We examine the possibility of this mechanism through interacting FDI employment with the sector dummy variables, including domestic private as the base group, domestic public, and foreign. Intriguingly, the coefficients of the interaction variables are all negative and significant, which suggests that an increase in local foreign hiring benefits workers in private domestic firms more compared to those in the public sector or foreign firms. Specifically, 1 standard deviation increase in local FDI employment is associated with $0.87 * 1.86=1.62$ percent increase in private-sector wage; $0.87 *(1.86-0.76)=0.96$ percent increase in public sector wage and only $0.87 *(1.86-0.88)=0.85$ percent increase in foreign sector wage. Given that there is a 20 percent and 11 percent wage premium for public and foreign sector workers over private-sector workers, this asymmetric effect suggests that increasing local FDI employment may provide an inequality-reduction impact. Model 4 reveals a similar story when looking at the differential impact based on the formality of jobs: Informal workers, who are paid on average 7.3 percent lower, experience a larger increase in wage level with surges in foreign hiring. A similar impact also extends to job security when comparing the wage growth for workers with and without permanent contracts. On average, temporary workers, who are paid 20 percent lower, are disproportionately benefit more from FDI

\footnotetext{
${ }^{35}$ Intriguingly, while the ratio of low and medium skilled workers in FDI firms increased from 2010-2015, the ratio of non-tertiary workers decreased. This signals that more workers are taking FDI jobs which they are overqualified for. More investigations in this direction are interesting but out of the scope of this paper.
} 
spillover. Given that nearly 50 percent of informal and temporary jobs are in supporting services such as construction, wholesale and retail trade, transport, and storage; and hotels and restaurants, our results provide clear evidence for the positive contribution of multinational firms on provincial aggregate demand.

Finally, we include interaction variables between provincial FDI employment and 19 industry dummies to examine its impact on cross-industry wage inequality for workers with similar demographics, skills, and educational levels. In Figure 3.9-upper, we plot the predicted increase in industry-specific average wage level from 1 standard deviation increase in provincial foreign hiring. Apart from education and training, the increasing presence of FDI firms benefits most industries, but there is considerable variation among industries, and not all estimated marginal effects are statistically significant at 5 percent level. The most significant increases mainly include supporting services such as IT, financial or administrative. We investigate the implication on wage inequality by comparing how industries rank among each other in terms of these predicted increases together with the average industry wage level over the sample period (Figure $3.9-$ lower). Overall, unlike previous interactions, the evidence is mixed. Among industries with the highest average wage levels, on the one hand, there are those which benefit significantly more from increasing foreign hiring such as financial, professional, or IT services. On the other hand, the impacts of foreign hiring are not significant for others such as real estate services and electricity, gas and steam supply, or even negative such as education and training. A similar pattern emerges when comparing industries such as hotels and restaurants or admin activities against others such as wholesale and retail trade or sewage and refuse disposal. Both groups fall into the lower bracket in terms of relative wage level, but the former benefits considerably more from provincial FDI employment.

In summary, we find strong evidence, both statistically and economically, that increasing FDI employment at province-level can reduce wage inequality across different sectors, skill levels, and educational levels. However, its impact on wage premiums across industries remains unclear.

\subsubsection{Provincial measures of inequality}

In our baseline model, we have examined the impact of FDI on wage inequality by testing whether surges in foreign hiring affect different groups of workers differently. In this section, we instead 
use direct measures of wage inequality as the dependent variable in a provincial-level regression with province and time fixed effects. Provincial wage inequality measures include the Gini coefficient, the relative mean deviation, Theil index; and P9010 and P8020 ratio. The last two measures are computed by the ratio between $90^{\text {th }}$ and $10^{\text {th }}$ percentile and between $80^{\text {th }}$ and $20^{\text {th }}$ percentile of the hourly wage distribution. Other covariates include the average provincial wage level and its squared term, average workers' age, the ratio of workers who are female, married, work informal jobs, or reside in urban regions, and the number of workers by educational attainment and occupational skill level. The first two terms are included to account for the potential Kuznets-type $^{36}$ inverse U-shape relationship between wage level and wage inequality while the rest are included to control for the impact of labour force's demographics structure. Similar to our baseline model, we use Bartik industry-share instrument to correct for potential endogeneity. Table 3.5 presents the results.

Our main variable of interest, local foreign hiring, is negative and statistically significant across all columns while other explanatory variables show expected signs. These results provide further supporting evidence for the wage inequality-reduction impact of FDI firms in the local labour market. For example, 1 standard deviation increase in FDI employment (0.87 in our sample) reduces the Gini index by 2.5 percent and decreases the P9010 and P8020 ratios by 0.1 and 0.02 , respectively.

\subsubsection{Robustness checks}

\subsubsection{FDI and unemployment rate}

In our main analysis, we have excluded unemployed workers from all model specifications. While convenient, this approach is not completely unproblematic. One of the main reasons for unemployment is that the reservation wage is higher than the market wage. As we cannot observe the market wage for unemployed workers, excluding them from the main sample may create biasedness to the estimated impact of FDI employment on wage inequality. In this section, we test whether FDI has a significant impact on unemployment at provincial level using a simple two-way fixed effect regression. We also control for other conventional determinants of the unemployment

\footnotetext{
${ }^{36}$ Kuznets (1955)
} 
rate, including inflation rate - calculated using the spatial cost of living index (SCOLI) ${ }^{37}$, growth rate of GDP per capita, and population growth rate. Table 3.6 presents the results, using FDI employment standardized by population in 2007 (Model 1) and by annual population (Model 2). In both specifications, the estimated coefficient of FDI is insignificant at all conventional levels which suggests that local FDI hiring has no clear impact on unemployment at provincial level. Therefore, it is likely that excluding unemployed workers from the sample due to unobserved individual-level market wage does not introduce bias to our main results.

\subsubsection{FDI and cross-province migration}

Another issue which deserves our attention is cross-province migration. First of all, workers may live in one province and work in another. Ideally, workers' market wages should mainly be affected by the surge in labour demand in the province where they work. For example, for a worker who lives in Hanoi but commutes to work in Thai Nguyen, the key explanatory variable should be the number of FDI jobs in Thai Nguyen instead of Ha Noi, as has been done in our model specifications. However, as the Labour Force Survey is household-based, workers are included in the sample according to their provinces of residence. One potential solution for this issue is using a Linked Employer-Employee Database in order to identify provinces of work. Unfortunately, this kind of dataset is not yet available for Vietnam.

Secondly, as FDI firms create surges in local labour demand, workers can also migrate from other provinces to take advantage of these new opportunities. If the scale of cross-province migration is large, our main coefficient of interest may be biased. For example, consider one FDI project in Ho Chi Minh city - the biggest city in Vietnam, and another in Bien Hoa - a neighboring province. Only workers in Bien Hoa may have incentives to move to Ho Chi Minh city to work or to provide supporting services but not vice-versa. In this case, the impact of FDI jobs on wage inequality can be estimated correctly in Ho Chi Minh city but not in Bien Hoa. If certain groups of workers are more likely to move, we may wrongly attribute the impact of migration on wage inequality in Bien Hoa to its local FDI project. To resolve this issue, we would need data on the in-migration and out-migration rates for each province. In our sample, this information is only available for the year 2015. Fortunately, the scale of cross-province migration is not large according to 2015 data. On

\footnotetext{
${ }^{37}$ We use the national consumer price index for Hanoi, the base province in SCOLI
} 
average, only 0.31 percent of workers in each province report moving there due to new job opportunities, and only one-third of them, around 0.11 percent moving there to work in the foreign sector. The rigid household registration system may be the main reason behind this. In summary, we are confident that our approach, in which cross-province migration is not explicitly controlled for, should not bias the results significantly, at least during our sample period.

\subsubsection{Alternative specifications}

We test the robustness of our results by (i) using logarithm of earnings instead of wage as the dependent variable and (ii) using occupational share instead of industry share to construct the Bartik instrument. Table 3.7 and 3.8 presents the results.

As the survey questionnaire records monthly earnings and weekly hours of work, we calculate our main dependent variable, hourly work by assuming workers work similar hours every week. This may not be the case for some workers. Therefore, we further test for robustness by re-estimating our baseline model using real earnings instead of real wage rate. This can also help disentangle the pure earning effects of FDI employment by factoring out its impact on hours of work. Overall, our results remain generally intact. Surges in local foreign hiring are positively associated with average earning, although the impact is not as strong as wage, both statistically and economically. From Table 3.7, column 2 shows that 1 standard deviation increase in FDI employment leads to approximately 1 percent increase in average earnings. Columns 3 and 4 provide evidence on a similar heterogeneous impact as in the wage regression, in which low-skilled and low-qualified workers benefit significantly more from foreign hiring.

Apart from the province's existing industrial structure, FDI firms may also consider the existing pool of local workers when forming their investment decisions. A local labour force with a similar skill mix with multinational firms' current productions would be more attractive as they seek to minimize hiring and production cost. Therefore, we use predetermined occupational level share in each province to construct another set of instruments for robustness check. From Table 3.8, Column 1-3 presents the result using only occupation-share instruments while Column 4-6 presents the results using both occupation-share and industry-share instruments to deal with FDI endogeneity. Overall, all estimated coefficients have expected signs although their statistical significances are not as strong as in the main model. In terms of the inequality-reduction impact 
of FDI, the evidence for decreasing wage premium for tertiary and higher degree holders remain robust.

\subsection{Conclusion}

Using individual-level data from the Household Labour Force Survey in Vietnam from 2010-2015, we study the impact of local labour demand shocks created by foreign multinational firms on wage inequality. We correct for potential reverse causality bias between local average wage level and FDI firms' locational decision by using Bartik-type instrument created from predetermined provincial industry labour share in 2007 and annual FDI employment at national level. We find strong evidence that more jobs created by multinational firms lead to an increase in average local wage. By allowing for the heterogeneous treatment effect, we also unveil a considerable variation in this positive impact. Workers with lower educational attainment or skill level are benefiting disproportionately more from surges in foreign hiring. Given the existing skill and degree wage premium, this asymmetric impact may help reduce wage inequality and raise the welfare for workers at the lower end of the wage distribution.

In Vietnam, both central and local authorities have been providing many incentives including tax breaks or preferential access to land and credit to attract FDI firms. Therefore, it is crucial to guarantee that this FDI-led growth model is both justifiable and sustainable. In chapter 2, we find that capital flow from multinational firms positively contributes towards both within-province economic growth and between-province income convergence. In this chapter, we reinforce our positive view towards FDI by showing that FDI jobs not only increase the average wage level but also help decrease the wage gap between low and high-skilled workers. During our period of study, because there are significant differences between the degree of FDI involvement among provinces, this dual benefit is mainly being enjoyed by a limited number of provinces. In the future, it is important for policymakers in Vietnam to ensure that FDI jobs are distributed more evenly across the country through continuously enhancing the investment climate and human capital endowment of poorer provinces. In addition, strategic and adequate investment in infrastructure to improve the connection between provinces and international connection hubs should also be high priorities in the policy agenda. 
In the future, some useful extensions may include: (i) incorporating the Enterprise Survey to disentangle the impact of different types of FDI jobs, (ii) reducing endogeneity bias by using different sets of instruments, or (iii) reducing estimation bias by controlling for firm-level information, possibly from linked employer-employee data. 


\section{Figures and Tables}

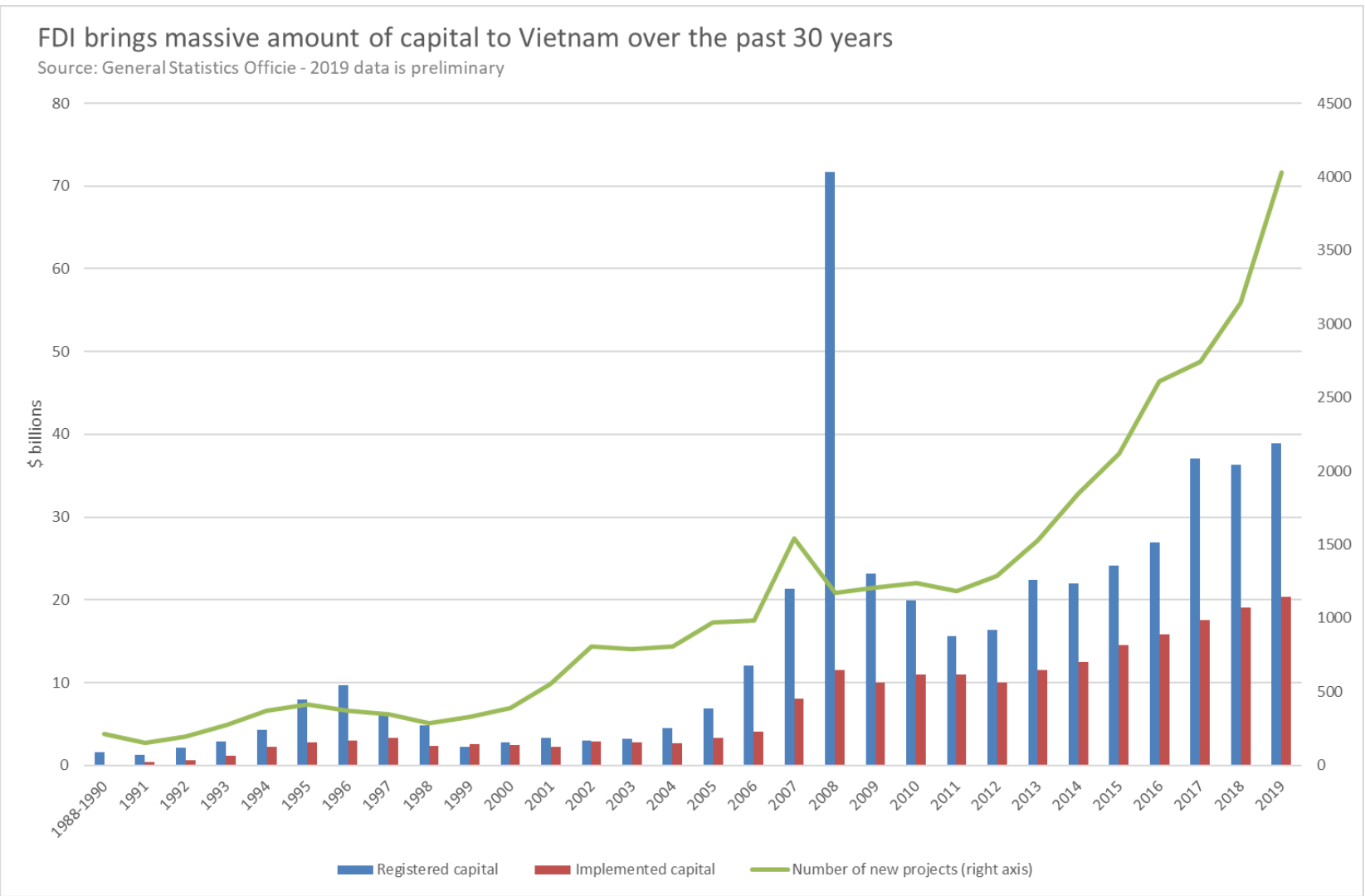

Figure 3.1 FDI capital in Vietnam 1999-2019

Source: GSO 


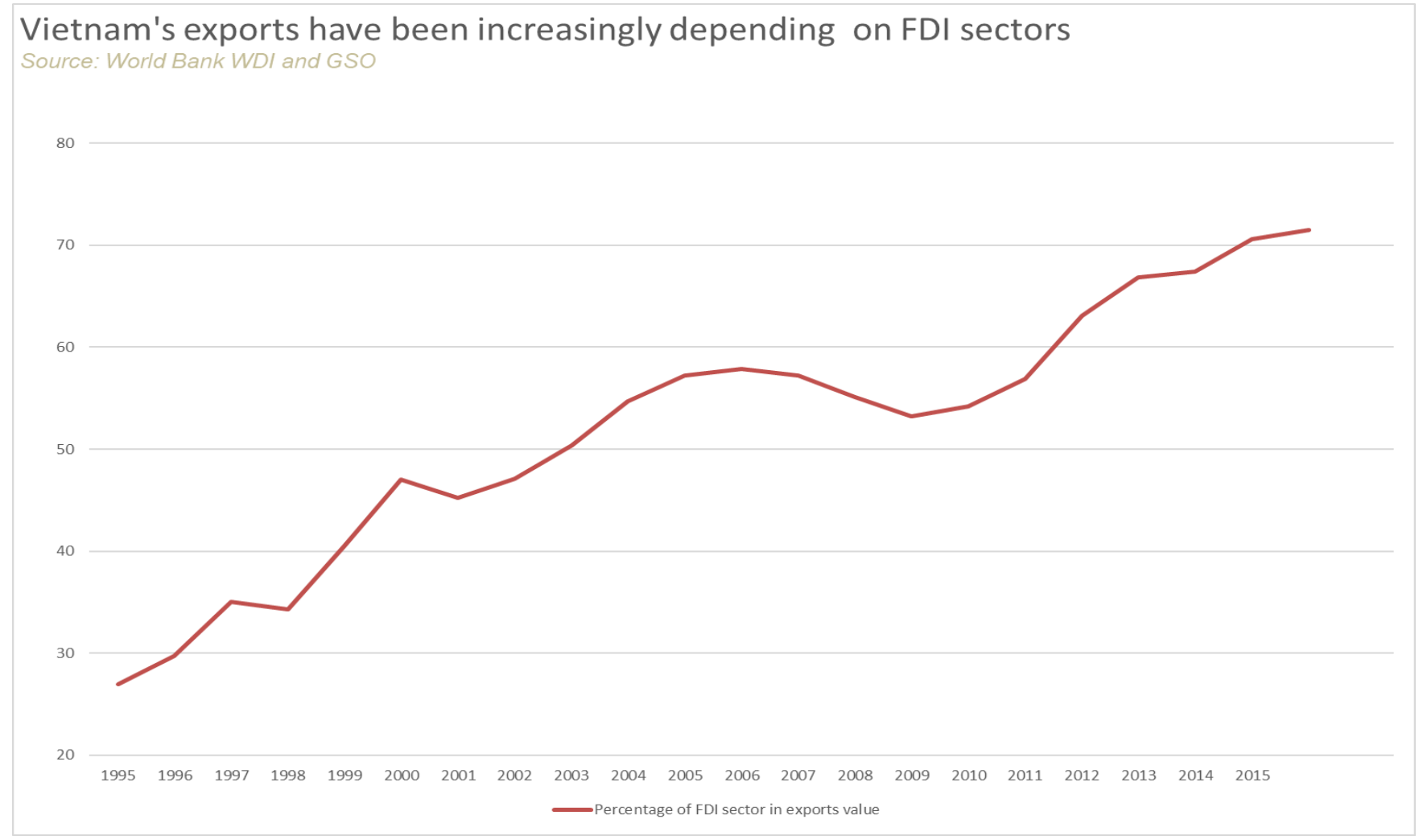

Figure 3.2 FDI's contribution in exports value (\%) - 1995-2015

Source: GSO 
Table 3.1 Summary statistics - Wage workers

\begin{tabular}{|c|c|c|c|c|c|c|}
\hline & 2010 & 2011 & 2012 & 2013 & 2014 & 2015 \\
\hline Percentage of labour force in wage-paying jobs (\%) & 35.41 & 36.40 & 36.64 & 36.85 & 37.83 & 42.17 \\
\hline \multirow[t]{2}{*}{ Monthly earnings (thousand dong) } & 2466.75 & 2693.81 & 2955.00 & 3117.16 & 3233.45 & 3251.62 \\
\hline & $(1805.54)$ & $(1960.28)$ & $(2081.39)$ & $(1885.93)$ & $(1908.91)$ & $(3404.69)$ \\
\hline \multirow[t]{2}{*}{ Hourly wage (thousand dong) } & 14.50 & 14.90 & 17.16 & 18.28 & 20.30 & 19.50 \\
\hline & $(26.47)$ & $(11.86)$ & $(14.97)$ & $(13.66)$ & $(19.78)$ & $(22.77)$ \\
\hline \multirow[t]{2}{*}{ Weekly hours worked } & 47.28 & 46.95 & 45.67 & 45.35 & 44.57 & 45.37 \\
\hline & $(9.36)$ & $(9.82)$ & $(10.10)$ & $(10.32)$ & $(10.98)$ & $(10.80)$ \\
\hline \multirow[t]{2}{*}{ Age } & 34.11 & 34.75 & 34.98 & 35.26 & 35.47 & 35.15 \\
\hline & (10.45) & (10.49) & (10.53) & (10.53) & (10.48) & (10.48) \\
\hline \multirow[t]{2}{*}{ Domestic sector } & 0.56 & 0.525 & 0.535 & 0.53 & 0.528 & 0.605 \\
\hline & $(0.50)$ & $(0.50)$ & $(0.50)$ & $(0.50)$ & $(0.50)$ & $(0.49)$ \\
\hline \multirow[t]{2}{*}{ Public sector } & 0.373 & 0.402 & 0.393 & 0.393 & 0.389 & 0.31 \\
\hline & $(0.48)$ & $(0.49)$ & $(0.49)$ & $(0.49)$ & $(0.49)$ & $(0.46)$ \\
\hline \multirow[t]{2}{*}{ Foreign sector } & 0.067 & 0.073 & 0.072 & 0.077 & 0.082 & 0.084 \\
\hline & $(0.25)$ & $(0.26)$ & $(0.26)$ & $(0.27)$ & $(0.28)$ & $(0.28)$ \\
\hline \multirow[t]{2}{*}{ Formal sector } & 0.578 & 0.497 & 0.515 & 0.769 & 0.779 & 0.766 \\
\hline & $(0.49)$ & $(0.50)$ & $(0.50)$ & $(0.42)$ & $(0.42)$ & $(0.42)$ \\
\hline \multirow[t]{2}{*}{ Female } & 0.418 & 0.423 & 0.422 & 0.426 & 0.429 & 0.421 \\
\hline & $(0.49)$ & $(0.49)$ & $(0.49)$ & $(0.50)$ & $(0.50)$ & $(0.49)$ \\
\hline \multirow[t]{2}{*}{ Urban } & 0.691 & 0.711 & 0.61 & 0.608 & 0.611 & 0.543 \\
\hline & $(0.46)$ & $(0.45)$ & $(0.49)$ & $(0.49)$ & $(0.49)$ & $(0.50)$ \\
\hline \multirow[t]{2}{*}{ Low-skilled } & 0.188 & 0.182 & 0.187 & 0.186 & 0.179 & 0.182 \\
\hline & $(0.39)$ & $(0.39)$ & $(0.39)$ & $(0.39)$ & $(0.38)$ & (0.39) \\
\hline \multirow[t]{2}{*}{ Medium-skilled } & 0.472 & 0.47 & 0.475 & 0.468 & 0.471 & 0.518 \\
\hline & $(0.50)$ & $(0.50)$ & $(0.50)$ & $(0.50)$ & $(0.50)$ & $(0.50)$ \\
\hline \multirow[t]{2}{*}{ High-skilled } & 0.34 & 0.349 & 0.338 & 0.346 & 0.35 & 0.3 \\
\hline & $(0.47)$ & $(0.48)$ & $(0.47)$ & $(0.48)$ & $(0.48)$ & $(0.46)$ \\
\hline \multirow[t]{2}{*}{ Primary or under } & 0.237 & 0.228 & 0.238 & 0.233 & 0.224 & 0.24 \\
\hline & $(0.43)$ & $(0.42)$ & $(0.43)$ & $(0.42)$ & $(0.42)$ & $(0.43)$ \\
\hline \multirow[t]{2}{*}{ Lower secondary } & 0.202 & 0.192 & 0.195 & 0.188 & 0.187 & 0.207 \\
\hline & $(0.40)$ & $(0.39)$ & $(0.40)$ & $(0.39)$ & $(0.39)$ & $(0.41)$ \\
\hline \multirow[t]{2}{*}{ Upper secondary } & 0.309 & 0.31 & 0.299 & 0.294 & 0.286 & 0.276 \\
\hline & $(0.46)$ & $(0.46)$ & $(0.46)$ & $(0.46)$ & $(0.45)$ & $(0.45)$ \\
\hline \multirow[t]{2}{*}{ Tertiary or higher } & 0.252 & 0.271 & 0.267 & 0.286 & 0.303 & 0.277 \\
\hline & $(0.43)$ & $(0.44)$ & $(0.44)$ & $(0.45)$ & $(0.46)$ & $(0.45)$ \\
\hline \multirow[t]{2}{*}{ Agricultural, forestry and fishing } & 0.095 & 0.092 & 0.101 & 0.097 & 0.09 & 0.081 \\
\hline & $(0.29)$ & $(0.29)$ & $(0.30)$ & $(0.30)$ & $(0.29)$ & $(0.27)$ \\
\hline \multirow[t]{2}{*}{ Mining and quarrying } & 0.013 & 0.013 & 0.013 & 0.012 & 0.011 & 0.011 \\
\hline & $(0.11)$ & $(0.11)$ & $(0.11)$ & $(0.11)$ & $(0.11)$ & $(0.11)$ \\
\hline \multirow[t]{2}{*}{ Manufacturing } & 0.239 & 0.237 & 0.237 & 0.24 & 0.245 & 0.278 \\
\hline & $(0.43)$ & $(0.43)$ & $(0.43)$ & $(0.43)$ & $(0.43)$ & $(0.45)$ \\
\hline \multirow[t]{2}{*}{ Construction } & 0.151 & 0.143 & 0.145 & 0.138 & 0.132 & 0.15 \\
\hline & $(0.36)$ & $(0.35)$ & $(0.35)$ & $(0.35)$ & $(0.34)$ & $(0.36)$ \\
\hline \multirow[t]{2}{*}{ Services } & 0.502 & 0.515 & 0.504 & 0.513 & 0.522 & 0.479 \\
\hline & $(0.50)$ & $(0.50)$ & $(0.50)$ & $(0.50)$ & $(0.50)$ & $(0.50)$ \\
\hline
\end{tabular}

Note: This table shows the sample mean of all the variables. Standard deviations are included in parentheses. Source: Authors' calculation from Vietnam Household Labour Force Survey, GSO 


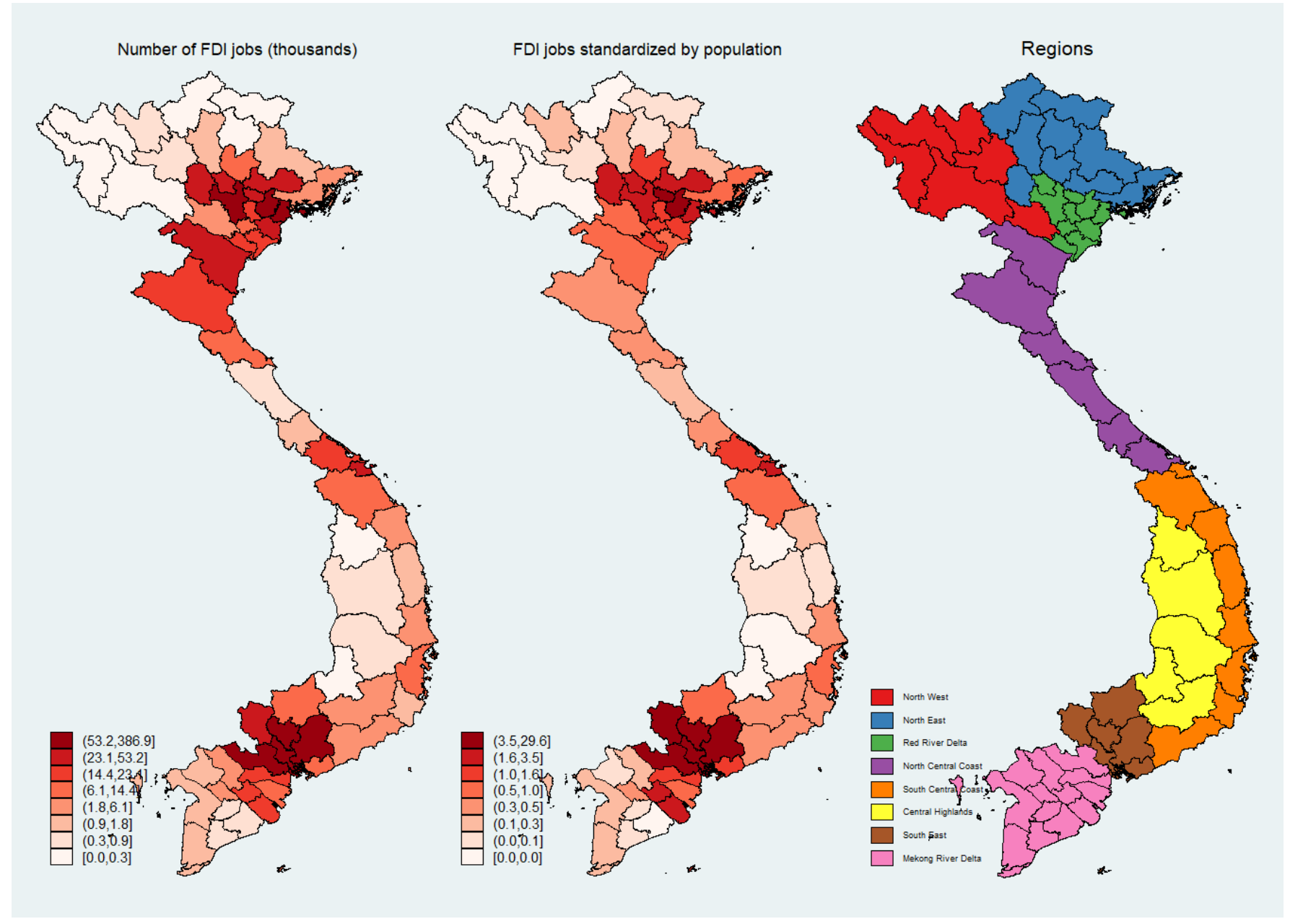

Figure 3.3 FDI jobs distribution by province - average 2010-2015

Source: Author's calculation from GSO's Household Labour Force Survey 


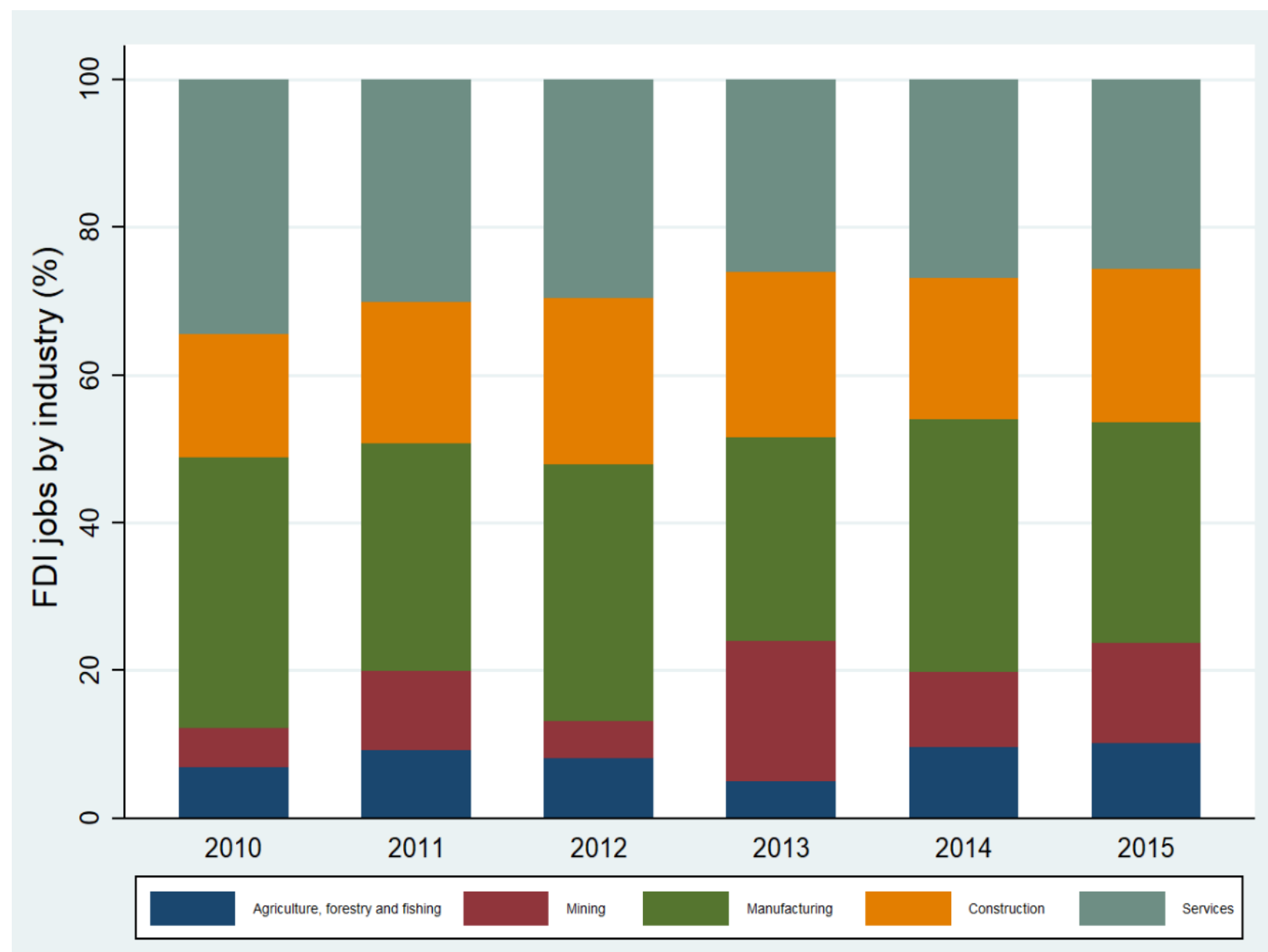

Figure 3.4 FDI jobs distribution by industry Source: Author's calculation from GSO's Household Labour Force Survey 


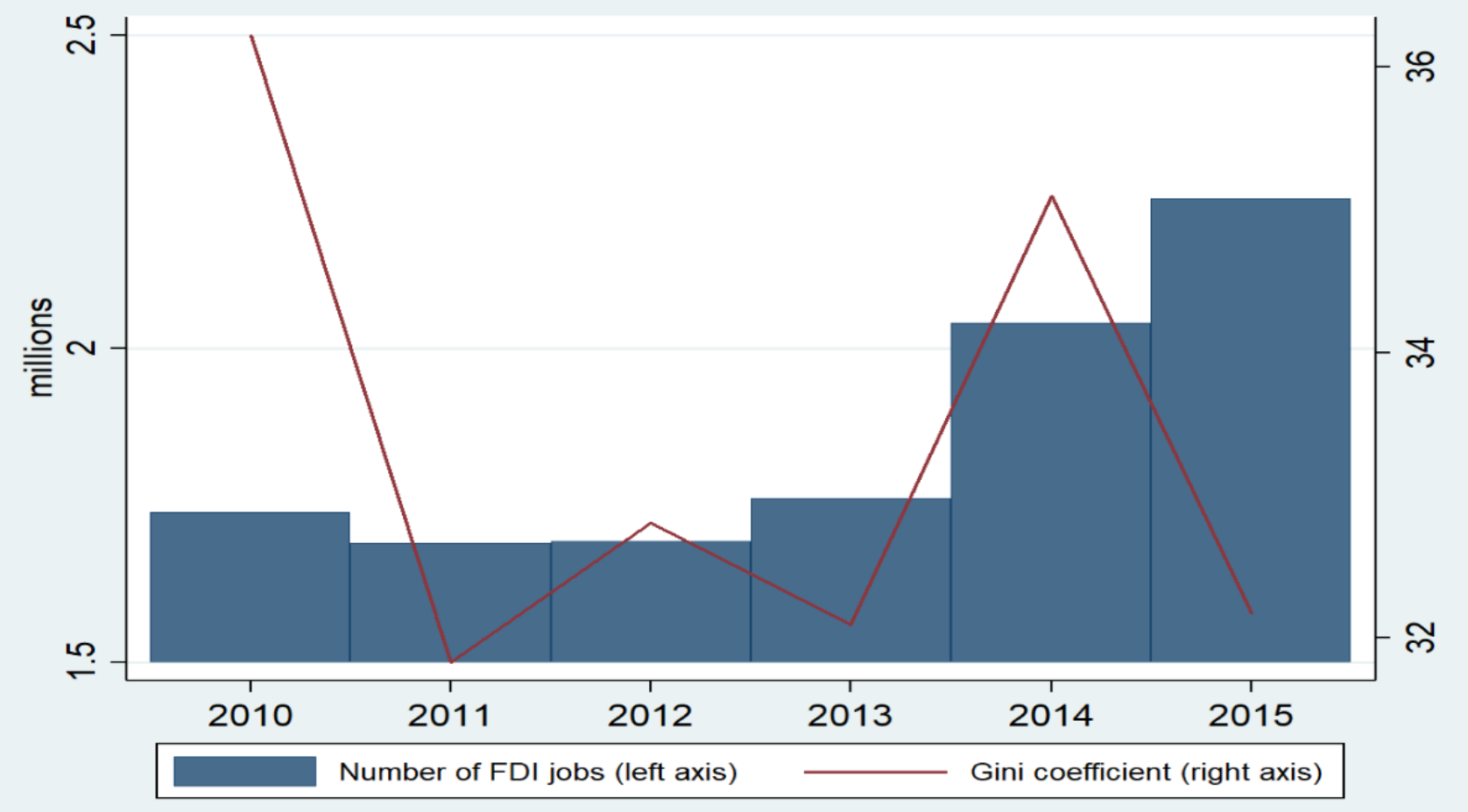

Figure 3.5 National wage Gini coefficient and number FDI jobs

Source: Author's calculation from GSO's Household Labour Force Survey 


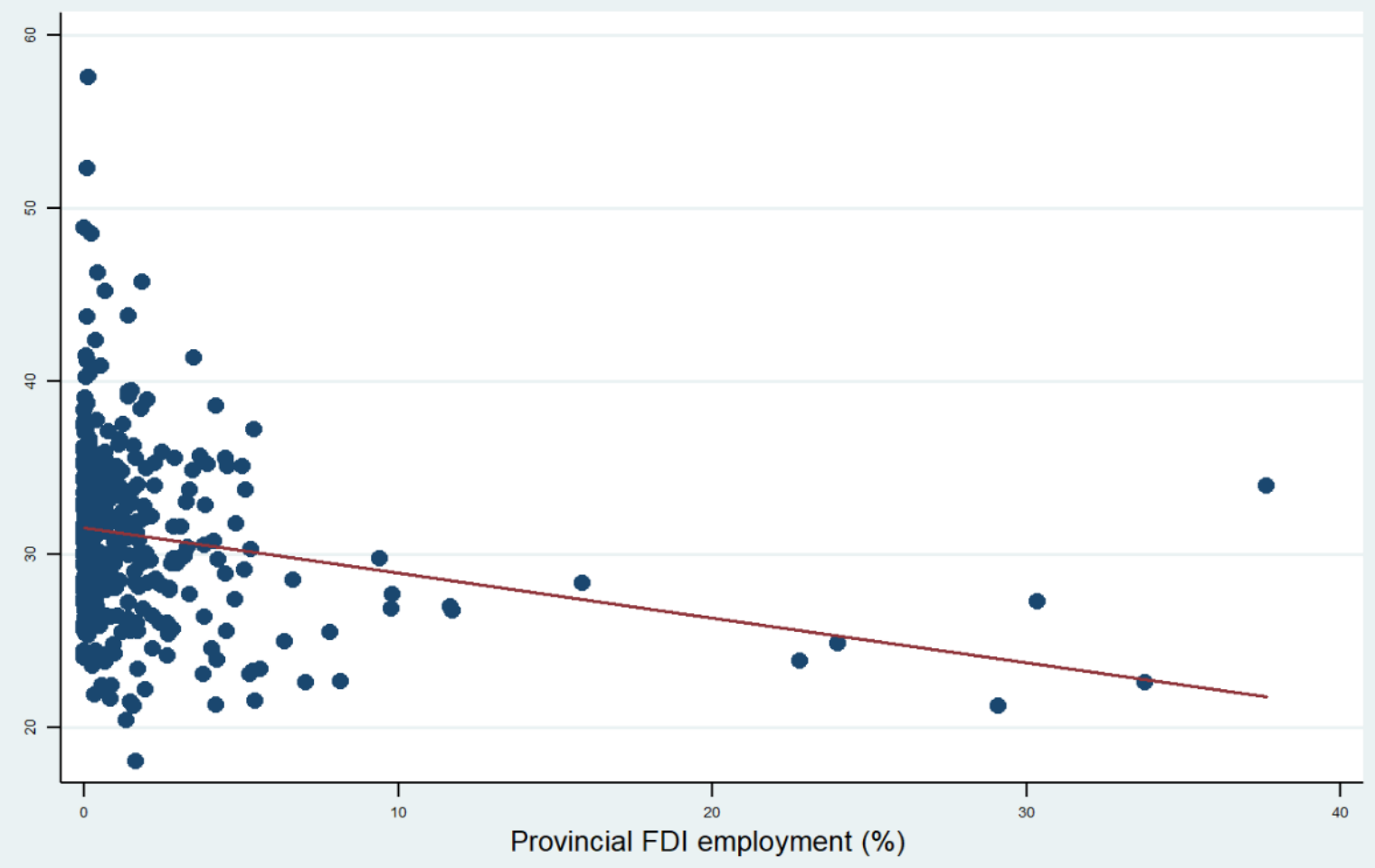

- Gini coefficient $\longrightarrow$ Fitted values

Figure 3.6 Provincial wage Gini coefficients and share of FDI jobs

Source: Author's calculation from GSO's Household Labour Force Survey 
Table 3.2 Baseline model - OLS

\begin{tabular}{|c|c|c|c|c|c|c|}
\hline VARIABLES & $\begin{array}{l}(1) \\
\text { OLS }\end{array}$ & $\begin{array}{c}(2) \\
\text { OLS }\end{array}$ & $\begin{array}{c}(3) \\
\text { OLS }\end{array}$ & $\begin{array}{c}(4) \\
\text { OLS }\end{array}$ & $\begin{array}{c}5) \\
\text { OLS }\end{array}$ & $\begin{array}{c}(6) \\
\text { OLS }\end{array}$ \\
\hline FDI employment & $\begin{array}{c}0.0114 \text { *** } \\
(0.002)\end{array}$ & $\begin{array}{c}0.0099 * * * \\
(0.002)\end{array}$ & $\begin{array}{c}0.0100^{* * * *} \\
(0.002)\end{array}$ & $\begin{array}{c}0.0096 \text { *** } \\
(0.002)\end{array}$ & $\begin{array}{c}0.0099 * * * \\
(0.002)\end{array}$ & $\begin{array}{c}0.0110 * * * \\
(0.003)\end{array}$ \\
\hline Sex & $\begin{array}{c}-0.1466 * * * \\
(0.010)\end{array}$ & $\begin{array}{c}-0.1642 * * * \\
(0.011)\end{array}$ & $\begin{array}{c}-0.1672 * * * \\
(0.011)\end{array}$ & $\begin{array}{c}-0.1742 * * * \\
(0.011)\end{array}$ & $\begin{array}{c}-0.1554 * * * \\
(0.011)\end{array}$ & $\begin{array}{c}-0.1569 * * * \\
(0.011)\end{array}$ \\
\hline Age & $\begin{array}{c}0.0328 * * * \\
(0.001)\end{array}$ & $\begin{array}{c}0.0336 * * * \\
(0.002)\end{array}$ & $\begin{array}{c}0.0337 * * * \\
(0.002)\end{array}$ & $\begin{array}{c}0.0332 * * * \\
(0.002)\end{array}$ & $\begin{array}{c}0.0284 * * * \\
(0.001)\end{array}$ & $\begin{array}{c}0.0271 * * * \\
(0.001)\end{array}$ \\
\hline Age squared & $\begin{array}{c}-0.0004 * * * \\
(0.000)\end{array}$ & $\begin{array}{c}-0.0004 * * * \\
(0.000)\end{array}$ & $\begin{array}{c}-0.0004 * * * \\
(0.000)\end{array}$ & $\begin{array}{c}-0.0004 * * * \\
(0.000)\end{array}$ & $\begin{array}{c}-0.0003 * * * \\
(0.000)\end{array}$ & $\begin{array}{c}-0.0003^{* * *} \\
(0.000)\end{array}$ \\
\hline Married & $\begin{array}{c}0.0636 \text { *** } \\
(0.005)\end{array}$ & $\begin{array}{c}0.0580^{* * * *} \\
(0.005)\end{array}$ & $\begin{array}{c}0.0581^{* * * *} \\
(0.005)\end{array}$ & $\begin{array}{c}0.0542^{* * * *} \\
(0.005)\end{array}$ & $\begin{array}{c}0.0509^{* * *} \\
(0.005)\end{array}$ & $\begin{array}{c}0.0465^{* * * *} \\
(0.005)\end{array}$ \\
\hline Urban & $\begin{array}{c}0.0792 * * * \\
(0.020)\end{array}$ & $\begin{array}{c}0.0791 * * * \\
(0.020)\end{array}$ & $\begin{array}{c}0.0757 * * * \\
(0.020)\end{array}$ & $\begin{array}{c}0.0735^{* * * *} \\
(0.020)\end{array}$ & $\begin{array}{c}0.0700^{* * * *} \\
(0.017)\end{array}$ & $\begin{array}{c}0.0647 \text { *** } \\
(0.017)\end{array}$ \\
\hline Lower secondary degree & $\begin{array}{c}0.0963 * * * \\
(0.009)\end{array}$ & $\begin{array}{c}0.0840 * * * \\
(0.008)\end{array}$ & $\begin{array}{c}0.0792 * * * \\
(0.008)\end{array}$ & $\begin{array}{c}0.0626 * * * \\
(0.007)\end{array}$ & $\begin{array}{c}0.0598 * * * \\
(0.007)\end{array}$ & $\begin{array}{c}0.0541 * * * \\
(0.006)\end{array}$ \\
\hline Upper secondary degree & $\begin{array}{c}0.2738 * * * \\
(0.011)\end{array}$ & $\begin{array}{c}0.2471 * * * \\
(0.010)\end{array}$ & $\begin{array}{c}0.2352 * * * \\
(0.010)\end{array}$ & $\begin{array}{c}0.1767 * * * \\
(0.009)\end{array}$ & $\begin{array}{c}0.1769 * * * \\
(0.008)\end{array}$ & $\begin{array}{c}0.1619 * * * \\
(0.009)\end{array}$ \\
\hline Tertiary degree or higher & $\begin{array}{c}0.6911 * * * \\
(0.018)\end{array}$ & $\begin{array}{c}0.6560 * * * \\
(0.023)\end{array}$ & $\begin{array}{c}0.6433 * * * \\
(0.023)\end{array}$ & $\begin{array}{c}0.4599 * * * \\
(0.013)\end{array}$ & $\begin{array}{c}0.4478 * * * \\
(0.012)\end{array}$ & $\begin{array}{c}0.4227 * * * \\
(0.012)\end{array}$ \\
\hline Public sector & & $\begin{array}{c}0.0615^{* * *} \\
(0.013)\end{array}$ & $\begin{array}{c}0.0322 * * \\
(0.013)\end{array}$ & $\begin{array}{r}-0.0146 \\
(0.011)\end{array}$ & $\begin{array}{c}0.0858 * * * \\
(0.011)\end{array}$ & $\begin{array}{c}0.0452 * * * \\
(0.010)\end{array}$ \\
\hline FDI sector & & $\begin{array}{c}0.1651^{* * *} \\
(0.020)\end{array}$ & $\begin{array}{c}0.1346^{* * *} \\
(0.019)\end{array}$ & $\begin{array}{c}0.1386^{* * * *} \\
(0.020)\end{array}$ & $\begin{array}{c}0.1424 * * * \\
(0.022)\end{array}$ & $\begin{array}{c}0.1289 * * * \\
(0.020)\end{array}$ \\
\hline Formal job & & & $\begin{array}{c}0.0554 * * * \\
(0.008)\end{array}$ & $\begin{array}{c}0.0361 * * * \\
(0.008)\end{array}$ & $\begin{array}{c}0.0590 * * * \\
(0.009)\end{array}$ & $\begin{array}{c}0.0604 * * * \\
(0.010)\end{array}$ \\
\hline Medium-skilled & & & & $\begin{array}{c}0.0907 * * * \\
(0.009)\end{array}$ & $\begin{array}{c}0.0995^{* * *} \\
(0.007)\end{array}$ & $\begin{array}{c}0.0936^{* * * *} \\
(0.007)\end{array}$ \\
\hline High-skilled & & & & $\begin{array}{c}0.3032 * * * \\
(0.014)\end{array}$ & $\begin{array}{c}0.3450 * * * \\
(0.010)\end{array}$ & $\begin{array}{c}0.3255^{* * * *} \\
(0.010)\end{array}$ \\
\hline Permanent contract & & & & & & $\begin{array}{c}0.1722 * * * \\
(0.012)\end{array}$ \\
\hline Constant & $\begin{array}{c}8.4593 * * * \\
(0.723)\end{array}$ & $\begin{array}{c}8.5695^{* * *} \\
(0.719)\end{array}$ & $\begin{array}{c}8.3696^{* * *} \\
(0.715)\end{array}$ & $\begin{array}{c}8.3061 \text { *** } \\
(0.711)\end{array}$ & $\begin{array}{c}8.3593^{* * *} * \\
(0.707)\end{array}$ & $\begin{array}{c}7.4490 \text { *** } \\
(0.763)\end{array}$ \\
\hline Observations & 971,597 & 971,597 & 971,597 & 971,597 & 971,597 & 971,597 \\
\hline R-squared & 0.357 & 0.364 & 0.365 & 0.377 & 0.399 & 0.407 \\
\hline Log Provincial CPI & YES & YES & YES & YES & YES & YES \\
\hline Time Dummies & YES & YES & YES & YES & YES & YES \\
\hline Province Dummies & YES & YES & YES & YES & YES & YES \\
\hline
\end{tabular}

Clustered standard errors at provincial level in parentheses. Province and year fixed effects are included in all models. $* * * \mathrm{p}<0.01, * * \mathrm{p}<0.05, * \mathrm{p}<0.10$ 
Table 3.3 Baseline model - IV

\begin{tabular}{|c|c|c|c|c|c|c|}
\hline VARIABLES & $\begin{array}{l}\text { (1) } \\
\text { IV }\end{array}$ & $\begin{array}{l}\text { (2) } \\
\text { IV }\end{array}$ & $\begin{array}{l}\text { (3) } \\
\text { IV }\end{array}$ & $\begin{array}{l}\text { (4) } \\
\text { IV }\end{array}$ & $\begin{array}{l}\text { (5) } \\
\text { IV }\end{array}$ & $\begin{array}{l}\text { (6) } \\
\text { IV }\end{array}$ \\
\hline FDI employment & $\begin{array}{c}0.0159^{*} \\
(0.009)\end{array}$ & $\begin{array}{c}0.0159^{*} \\
(0.009)\end{array}$ & $\begin{array}{c}0.0141^{*} \\
(0.008)\end{array}$ & $\begin{array}{l}0.0133 \\
(0.008)\end{array}$ & $\begin{array}{c}0.0140^{*} \\
(0.008)\end{array}$ & $\begin{array}{c}0.0141^{*} \\
(0.007)\end{array}$ \\
\hline Sex & $\begin{array}{c}-0.1466 \text { *** } \\
(0.010)\end{array}$ & $\begin{array}{c}-0.1641 * * * \\
(0.011)\end{array}$ & $\begin{array}{c}-0.1671 * * * \\
(0.011)\end{array}$ & $\begin{array}{c}-0.1741 * * * \\
(0.011)\end{array}$ & $\begin{array}{c}-0.1554 * * * \\
(0.011)\end{array}$ & $\begin{array}{c}-0.1568 * * * \\
(0.011)\end{array}$ \\
\hline Age & $\begin{array}{c}0.0328 * * * \\
(0.001)\end{array}$ & $\begin{array}{c}0.0336 \text { *** } \\
(0.002)\end{array}$ & $\begin{array}{c}0.0337 * * * \\
(0.001)\end{array}$ & $\begin{array}{c}0.0332 * * * \\
(0.002)\end{array}$ & $\begin{array}{c}0.0284 * * * \\
(0.001)\end{array}$ & $\begin{array}{c}0.0271 * * * \\
(0.001)\end{array}$ \\
\hline Age squared & $\begin{array}{c}-0.0004 * * * \\
(0.000)\end{array}$ & $\begin{array}{c}-0.0004 * * * \\
(0.000)\end{array}$ & $\begin{array}{c}-0.0004 * * * \\
(0.000)\end{array}$ & $\begin{array}{c}-0.0004 * * * \\
(0.000)\end{array}$ & $\begin{array}{c}-0.0003 * * * \\
(0.000)\end{array}$ & $\begin{array}{c}-0.0003 * * * \\
(0.000)\end{array}$ \\
\hline Married & $\begin{array}{c}0.0635^{* * *} \\
(0.005)\end{array}$ & $\begin{array}{c}0.0578^{* * *} \\
(0.005)\end{array}$ & $\begin{array}{c}0.0579 * * * \\
(0.005)\end{array}$ & $\begin{array}{c}0.0541 * * * \\
(0.005)\end{array}$ & $\begin{array}{c}0.0508 * * * \\
(0.005)\end{array}$ & $\begin{array}{c}0.0464 * * * \\
(0.005)\end{array}$ \\
\hline Urban & $\begin{array}{c}0.0785^{* * *} * \\
(0.020)\end{array}$ & $\begin{array}{c}0.0781 * * * \\
(0.020)\end{array}$ & $\begin{array}{c}0.0751 * * * \\
(0.019)\end{array}$ & $\begin{array}{c}0.0729 * * * \\
(0.020)\end{array}$ & $\begin{array}{c}0.0693 * * * \\
(0.017)\end{array}$ & $\begin{array}{c}0.0642 * * * \\
(0.017)\end{array}$ \\
\hline Lower secondary degree & $\begin{array}{c}0.0963 * * * \\
(0.009)\end{array}$ & $\begin{array}{c}0.0841 * * * \\
(0.008)\end{array}$ & $\begin{array}{c}0.0792 * * * \\
(0.008)\end{array}$ & $\begin{array}{c}0.0626^{* * * *} \\
(0.007)\end{array}$ & $\begin{array}{c}0.0598 * * * \\
(0.006)\end{array}$ & $\begin{array}{c}0.0541 * * * \\
(0.006)\end{array}$ \\
\hline Upper secondary degree & $\begin{array}{c}0.2738 * * * \\
(0.011)\end{array}$ & $\begin{array}{c}0.2472 * * * \\
(0.010)\end{array}$ & $\begin{array}{c}0.2352 * * * \\
(0.010)\end{array}$ & $\begin{array}{c}0.1768 * * * \\
(0.009)\end{array}$ & $\begin{array}{c}0.1770 * * * \\
(0.008)\end{array}$ & $\begin{array}{c}0.1620 * * * \\
(0.009)\end{array}$ \\
\hline Tertiary degree or higher & $\begin{array}{c}0.6914 * * * \\
(0.018)\end{array}$ & $\begin{array}{c}0.6563^{* * * *} \\
(0.023)\end{array}$ & $\begin{array}{c}0.6434 * * * \\
(0.022)\end{array}$ & $\begin{array}{c}0.4601 * * * \\
(0.012)\end{array}$ & $\begin{array}{c}0.4481 * * * \\
(0.012)\end{array}$ & $\begin{array}{c}0.4229 * * * \\
(0.012)\end{array}$ \\
\hline Public sector & & $\begin{array}{c}0.0616^{* * * *} \\
(0.013)\end{array}$ & $\begin{array}{c}0.0322 * * \\
(0.013)\end{array}$ & $\begin{array}{c}-0.0146 \\
(0.011)\end{array}$ & $\begin{array}{c}0.0858 * * * \\
(0.011)\end{array}$ & $\begin{array}{c}0.0452 * * * \\
(0.010)\end{array}$ \\
\hline FDI sector & & $\begin{array}{c}0.1638 * * * \\
(0.019)\end{array}$ & $\begin{array}{c}0.1337 * * * \\
(0.018)\end{array}$ & $\begin{array}{c}0.1377 * * * \\
(0.018)\end{array}$ & $\begin{array}{c}0.1414 * * * \\
(0.020)\end{array}$ & $\begin{array}{c}0.1282 * * * \\
(0.019)\end{array}$ \\
\hline Formal job & & & $\begin{array}{c}0.0555^{* * *} * \\
(0.008)\end{array}$ & $\begin{array}{c}0.0363 * * * \\
(0.008)\end{array}$ & $\begin{array}{c}0.0593 * * * \\
(0.009)\end{array}$ & $\begin{array}{c}0.0606^{* * * *} \\
(0.010)\end{array}$ \\
\hline Medium-skilled & & & & $\begin{array}{c}0.0907 * * * \\
(0.008)\end{array}$ & $\begin{array}{c}0.0996 * * * \\
(0.007)\end{array}$ & $\begin{array}{c}0.0936^{* * * *} \\
(0.007)\end{array}$ \\
\hline High-skilled & & & & $\begin{array}{c}0.3030 * * * \\
(0.014)\end{array}$ & $\begin{array}{c}0.3448 * * * \\
(0.010)\end{array}$ & $\begin{array}{c}0.3254 * * * \\
(0.010)\end{array}$ \\
\hline Permanent contract & & & & & & $\begin{array}{c}0.1725^{* * * *} \\
(0.013)\end{array}$ \\
\hline Constant & $\begin{array}{c}8.7482 * * * \\
(0.477)\end{array}$ & $\begin{array}{c}8.9564 * * * \\
(0.507)\end{array}$ & $\begin{array}{c}8.6261 * * * \\
(0.442)\end{array}$ & $\begin{array}{c}8.5423 * * * \\
(0.444)\end{array}$ & $\begin{array}{c}8.6201 * * * \\
(0.439)\end{array}$ & $\begin{array}{c}7.6472 * * * \\
(0.535)\end{array}$ \\
\hline Observations & 971,597 & 971,597 & 971,597 & 971,597 & 971,597 & 971,597 \\
\hline R-squared & 0.357 & 0.363 & 0.365 & 0.377 & 0.399 & 0.407 \\
\hline Log Provincial CPI & YES & YES & YES & YES & YES & YES \\
\hline Time Dummies & YES & YES & YES & YES & YES & YES \\
\hline Province Dummies & YES & YES & YES & YES & YES & YES \\
\hline
\end{tabular}

Clustered standard errors at provincial level in parentheses. Province and year fixed effects are included in all models. $* * * \mathrm{p}<0.01, * * \mathrm{p}<0.05, * \mathrm{p}<0.10$ 


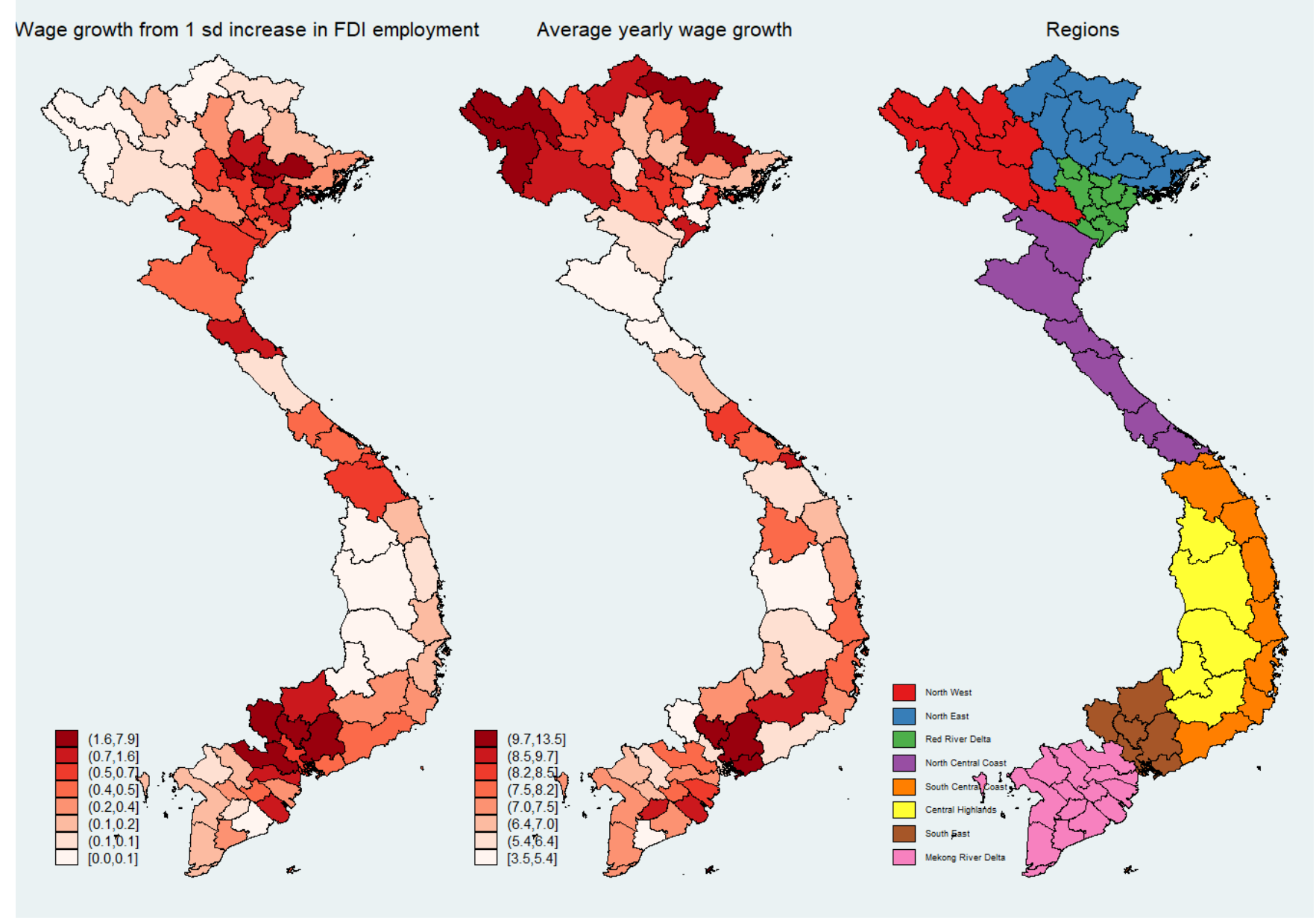

Figure 3.7 Economic significance of FDI employment

Source: Author's calculation from GSO's Household Labour Force Survey 
Table 3.4 Heterogeneous impact of FDI employment

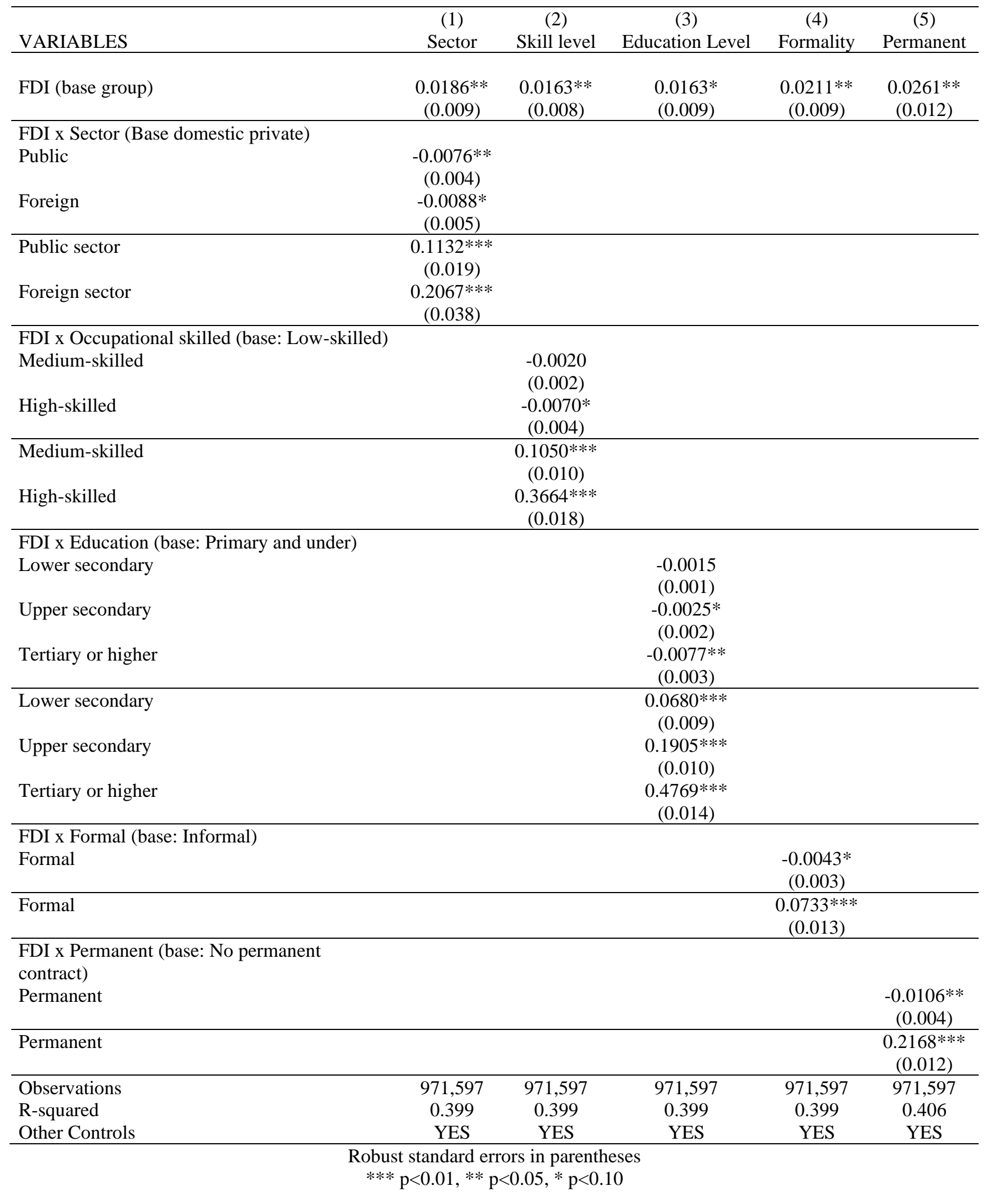



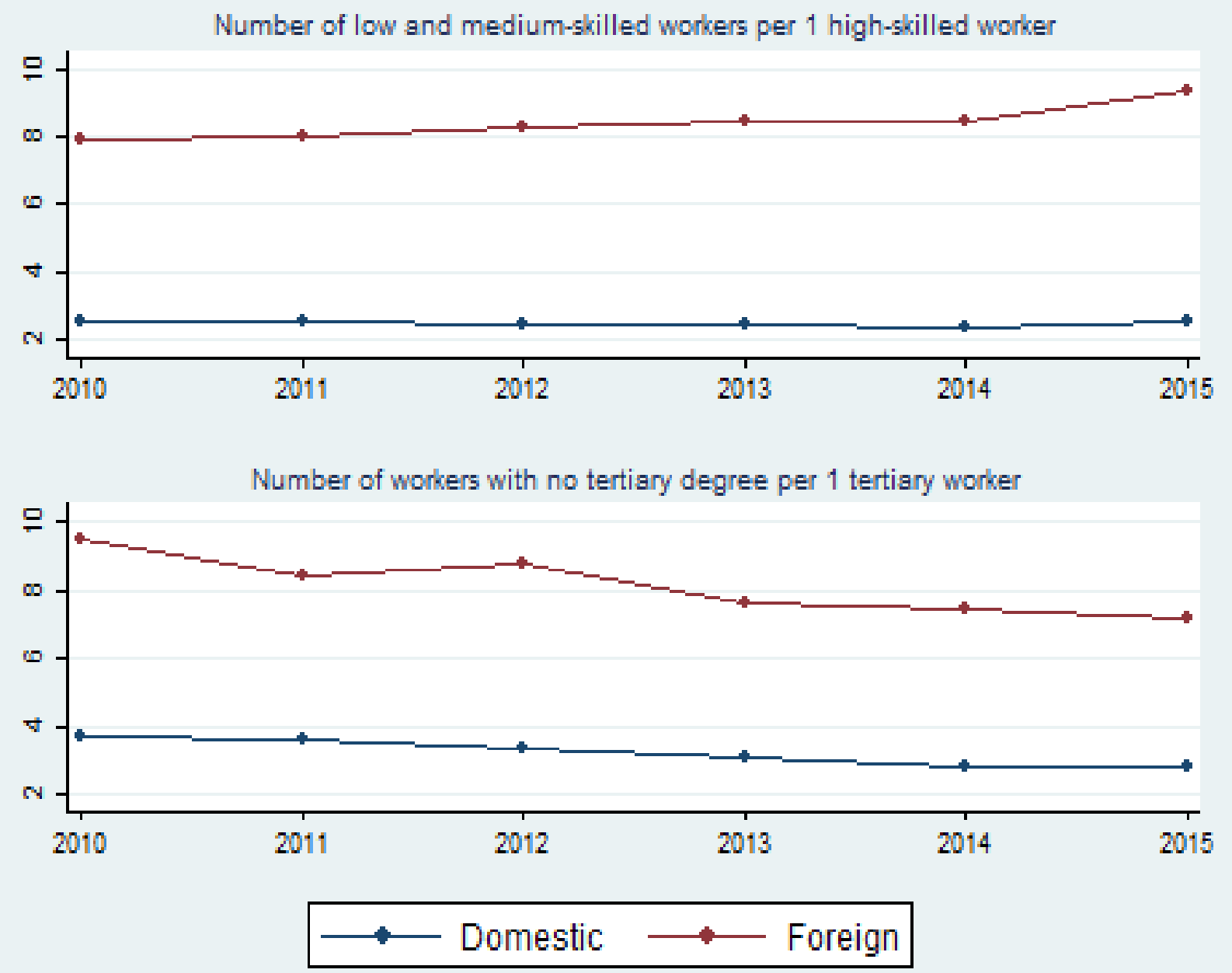

Figure 3.8 Skill structure of domestic and foreign firms Source: Author's calculation from GSO's Household Labour Force Survey 
Predicted wage increase from 1 standard deviation increase in provincial FDI employment (\%)

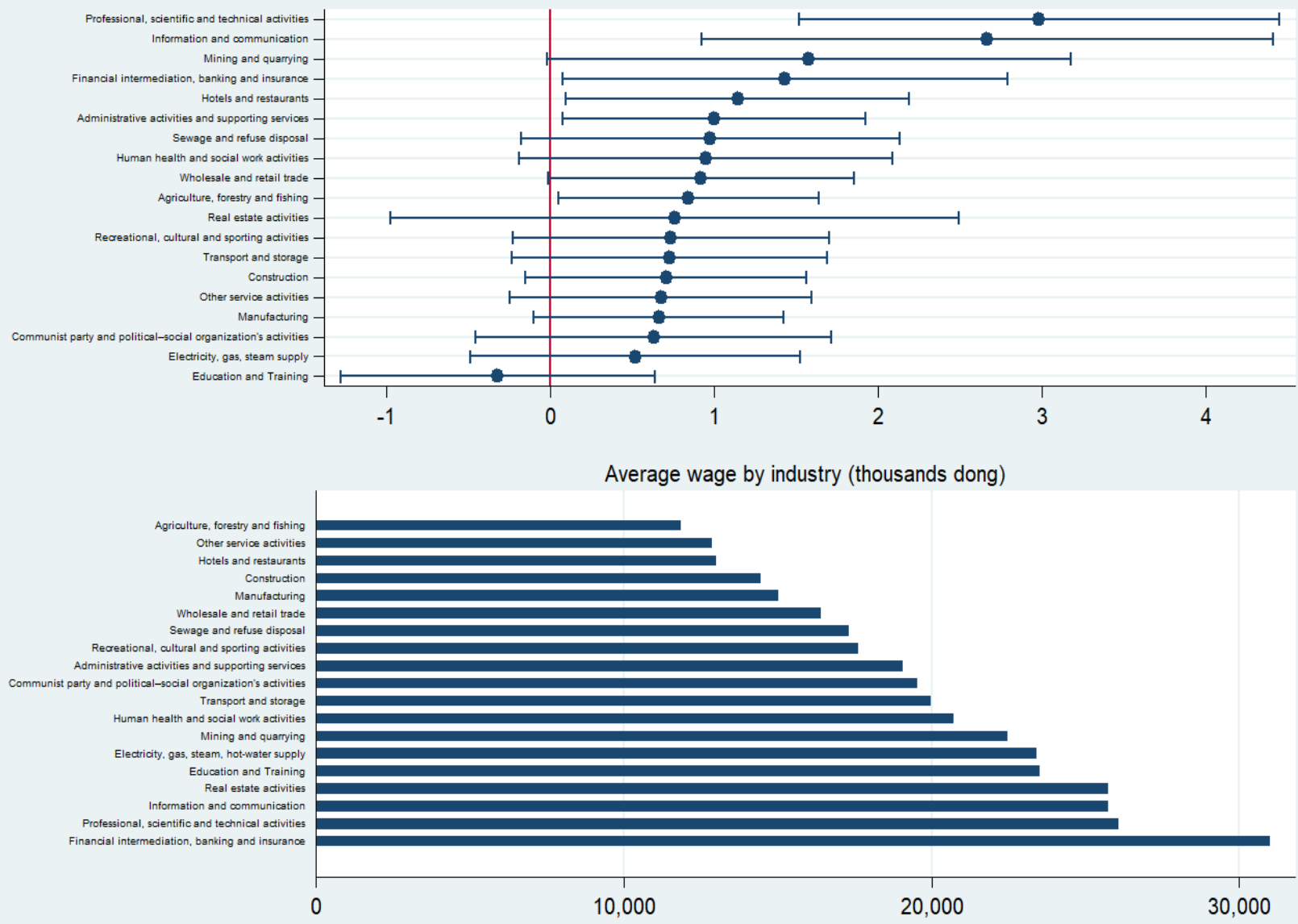

Figure 3.9 Heterogeneous impact by industry

Source: Author's calculation. The upper graph includes both the point estimates and $95 \%$ confidence intervals 
Table 3.5 Provincial measure of inequality - IV

\begin{tabular}{|c|c|c|c|c|c|}
\hline VARIABLES & $\begin{array}{c}\text { (1) } \\
\text { Gini }\end{array}$ & $\begin{array}{c}(2) \\
\text { RMD }\end{array}$ & $\begin{array}{c}(3) \\
\text { P9010 }\end{array}$ & $\begin{array}{c}(4) \\
\text { P8020 }\end{array}$ & $\begin{array}{c}\text { (5) } \\
\text { Theil }\end{array}$ \\
\hline FDI employment & $\begin{array}{c}-0.0297 * * \\
(0.012)\end{array}$ & $\begin{array}{c}-0.4940 * \\
(0.275)\end{array}$ & $\begin{array}{c}-0.1146 * \\
(0.075)\end{array}$ & $\begin{array}{l}-0.0266 \\
(0.028)\end{array}$ & $\begin{array}{l}-1.7438 \\
(1.072)\end{array}$ \\
\hline Average wage & $\begin{array}{c}0.1257 * * * \\
(0.012)\end{array}$ & $\begin{array}{c}3.5641^{* * *} \\
(0.344)\end{array}$ & $\begin{array}{l}0.0031 \\
(0.084)\end{array}$ & $\begin{array}{l}0.0112 \\
(0.027)\end{array}$ & $\begin{array}{c}14.1403^{* * * *} \\
(1.643)\end{array}$ \\
\hline Average wage squared & $\begin{array}{c}-0.0018^{* * *} \\
(0.000)\end{array}$ & $\begin{array}{c}-0.0525^{* * *} \\
(0.007)\end{array}$ & $\begin{array}{l}0.0023 \\
(0.002)\end{array}$ & $\begin{array}{l}0.0002 \\
(0.001)\end{array}$ & $\begin{array}{c}-0.2259^{* * *} \\
(0.033)\end{array}$ \\
\hline Ratio of female workers & $\begin{array}{l}-0.4165 \\
(0.319)\end{array}$ & $\begin{array}{l}-6.9735 \\
(7.477)\end{array}$ & $\begin{array}{c}-2.5956^{*} \\
(1.412)\end{array}$ & $\begin{array}{l}-0.6050 \\
(0.532)\end{array}$ & $\begin{array}{c}6.1168 \\
(31.273)\end{array}$ \\
\hline Average age & $\begin{array}{l}-0.0075 \\
(0.010)\end{array}$ & $\begin{array}{l}-0.0482 \\
(0.271)\end{array}$ & $\begin{array}{l}-0.0170 \\
(0.071)\end{array}$ & $\begin{array}{l}-0.0098 \\
(0.031)\end{array}$ & $\begin{array}{l}-0.2662 \\
(1.118)\end{array}$ \\
\hline Ratio of married workers & $\begin{array}{l}-0.2165 \\
(0.245)\end{array}$ & $\begin{array}{c}-10.3289 * \\
(5.590)\end{array}$ & $\begin{array}{l}-0.5120 \\
(1.531)\end{array}$ & $\begin{array}{l}-0.0116 \\
(0.540)\end{array}$ & $\begin{array}{l}-31.9908 \\
(24.226)\end{array}$ \\
\hline Ratio of urban workers & $\begin{array}{l}0.1642 \\
(0.109)\end{array}$ & $\begin{array}{l}1.5868 \\
(3.020)\end{array}$ & $\begin{array}{l}0.2294 \\
(0.700)\end{array}$ & $\begin{array}{l}0.0227 \\
(0.314)\end{array}$ & $\begin{array}{c}7.4262 \\
(10.879)\end{array}$ \\
\hline Ratio of formal workers & $\begin{array}{l}-0.0667 \\
(0.101)\end{array}$ & $\begin{array}{l}-2.0551 \\
(2.219)\end{array}$ & $\begin{array}{l}-0.6185 \\
(0.680)\end{array}$ & $\begin{array}{l}-0.1672 \\
(0.217)\end{array}$ & $\begin{array}{l}-9.7026 \\
(9.568)\end{array}$ \\
\hline Ratio of workers with lower secondary degree & $\begin{array}{l}-0.2280 \\
(0.225)\end{array}$ & $\begin{array}{l}-7.9712 \\
(6.085)\end{array}$ & $\begin{array}{l}-0.9605 \\
(1.343)\end{array}$ & $\begin{array}{l}-0.1546 \\
(0.547)\end{array}$ & $\begin{array}{c}-40.9219^{*} \\
(23.963)\end{array}$ \\
\hline Ratio of workers with upper secondary degree & $\begin{array}{l}-0.2236 \\
(0.262)\end{array}$ & $\begin{array}{l}-5.1746 \\
(7.062)\end{array}$ & $\begin{array}{l}0.2941 \\
(1.392)\end{array}$ & $\begin{array}{l}0.1552 \\
(0.607)\end{array}$ & $\begin{array}{l}-35.8699 \\
(24.357)\end{array}$ \\
\hline Ratio of workers with tertiary degree or higher & $\begin{array}{l}0.0211 \\
(0.410)\end{array}$ & $\begin{array}{l}-0.0048 \\
(11.072)\end{array}$ & $\begin{array}{l}1.6281 \\
(2.125)\end{array}$ & $\begin{array}{l}0.9373 \\
(0.930)\end{array}$ & $\begin{array}{l}-14.6016 \\
(42.249)\end{array}$ \\
\hline Ratio of low-skilled workers & $\begin{array}{l}-0.1961 \\
(0.182)\end{array}$ & $\begin{array}{r}-3.0652 \\
(6.508)\end{array}$ & $\begin{array}{l}-0.9645 \\
(0.850)\end{array}$ & $\begin{array}{l}-0.5339 \\
(0.337)\end{array}$ & $\begin{array}{l}-0.5177 \\
(26.360)\end{array}$ \\
\hline Ratio of medium-skilled workers & $\begin{array}{c}-0.6964^{*} \\
(0.391)\end{array}$ & $\begin{array}{c}-18.3159^{*} \\
(10.350)\end{array}$ & $\begin{array}{l}-1.7539 \\
(1.983)\end{array}$ & $\begin{array}{l}-0.8436 \\
(0.874)\end{array}$ & $\begin{array}{r}-50.3560 \\
(35.573)\end{array}$ \\
\hline Ratio of workers with permanent contract & $\begin{array}{l}-0.1393 \\
(0.088)\end{array}$ & $\begin{array}{c}-3.9175^{*} \\
(2.193)\end{array}$ & $\begin{array}{l}-0.4884 \\
(0.612)\end{array}$ & $\begin{array}{l}0.2616 \\
(0.215)\end{array}$ & $\begin{array}{c}-15.2638^{*} \\
(8.977)\end{array}$ \\
\hline Observations & 378 & 378 & 378 & 378 & 378 \\
\hline Number of provinces & 63 & 63 & 63 & 63 & 63 \\
\hline
\end{tabular}

Clustered standard errors at provincial level in parentheses. Province and year fixed effects are included in all models.

$$
* * * \mathrm{p}<0.01, * * \mathrm{p}<0.05, * \mathrm{p}<0.10
$$


Table 3.6 The impact of FDI on unemployment rate

\begin{tabular}{lcc}
\hline & \multicolumn{2}{c}{ Dependent variable: Provincial unemployment rate } \\
\cline { 2 - 3 } VARIABLES & $(1)$ & $(2)$ \\
FDI & 0.0086 & 0.0117 \\
& $(0.037)$ & $(0.049)$ \\
Inflation rate & $-0.0392^{* *}$ & $-0.0391 * *$ \\
& $(0.016)$ & $(0.016)$ \\
Population growth rate & $0.5043^{* * *}$ & $0.5002^{* * *}$ \\
& $(0.151)$ & $(0.150)$ \\
GDP growth rate & -0.0008 & -0.0008 \\
& $(0.007)$ & $(0.007)$ \\
Constant & $1.3652^{* * *}$ & $1.3648 * * *$ \\
& $(0.172)$ & $(0.172)$ \\
Observations & 300 & 300 \\
R-squared & 0.718 & 0.718 \\
Number of provinces & 60 & 60 \\
\hline
\end{tabular}

Standard errors in parentheses. Number of FDI jobs is standardized by 2007 population in Model 1 and by annual population in Model 2

$* * * \mathrm{p}<0.01, * * \mathrm{p}<0.05, * \mathrm{p}<0.10$ 
Table 3.7 Robustness - Logarithm of earnings

\begin{tabular}{|c|c|c|c|c|}
\hline & (1) & (2) & (3) & (4) \\
\hline VARIABLES & OLS-earnings & IV-earnings & IV-earnings & IV-earnings \\
\hline \multirow[t]{2}{*}{ FDI employment } & $0.0065 * * *$ & 0.0103 & $0.0142 *$ & 0.0136 \\
\hline & $(0.001)$ & $(0.008)$ & $(0.008)$ & $(0.008)$ \\
\hline \multicolumn{5}{|l|}{ FDI x Occupational level } \\
\hline \multicolumn{5}{|l|}{ Base group: Lower-skilled } \\
\hline \multirow[t]{2}{*}{ Medium-skilled } & & & $-0.0035^{*}$ & \\
\hline & & & $(0.002)$ & \\
\hline \multirow[t]{2}{*}{ High-skilled } & & & $-0.0098 * * *$ & \\
\hline & & & $(0.003)$ & \\
\hline \multicolumn{5}{|l|}{ FDI x Education level } \\
\hline \multicolumn{5}{|l|}{ Base group: Primary or under } \\
\hline \multirow[t]{2}{*}{ Lower secondary high school } & & & & -0.0019 \\
\hline & & & & $(0.002)$ \\
\hline \multirow[t]{2}{*}{ Upper secondary high school } & & & & $-0.0034 * *$ \\
\hline & & & & $(0.002)$ \\
\hline \multirow[t]{2}{*}{ Tertiary or higher } & & & & $-0.0112 * * *$ \\
\hline & & & & $(0.003)$ \\
\hline \multirow[t]{2}{*}{ Constant } & $6.8562 * * *$ & $7.0982 * * *$ & $7.0641 * * *$ & $7.1173 * * *$ \\
\hline & $(0.646)$ & $(0.457)$ & $(0.449)$ & $(0.449)$ \\
\hline Observations & 971,597 & 971,597 & 971,597 & 971,597 \\
\hline R-squared & 0.404 & 0.404 & 0.405 & 0.405 \\
\hline Other Controls & YES & YES & YES & YES \\
\hline
\end{tabular}

Clustered standard errors at provincial level in parentheses. Province and year fixed effects are included in all models.

$$
* * * \mathrm{p}<0.01, * * \mathrm{p}<0.05, * \mathrm{p}<0.10
$$


Table 3.8 Robustness - Alternative instrument

\begin{tabular}{|c|c|c|c|c|c|c|}
\hline \multirow[b]{2}{*}{ VARIABLES } & \multicolumn{3}{|c|}{ Instrument: Occupation-share } & \multicolumn{3}{|c|}{ Instrument: Occupation-share and industry share } \\
\hline & (1) & (2) & (3) & (4) & (5) & (6) \\
\hline \multirow[t]{2}{*}{ FDI } & 0.0122 & 0.0137 & 0.0131 & 0.0133 & $0.0152 *$ & $0.0144 *$ \\
\hline & $(0.009)$ & $(0.009)$ & $(0.009)$ & $(0.008)$ & $(0.008)$ & $(0.008)$ \\
\hline \multicolumn{7}{|l|}{ FDI x Occupational level } \\
\hline \multicolumn{7}{|l|}{ Base group: Low-skilled } \\
\hline \multirow[t]{2}{*}{ Medium-skilled } & & -0.0013 & & & -0.0015 & \\
\hline & & $(0.001)$ & & & $(0.001)$ & \\
\hline \multirow[t]{2}{*}{ High-skilled } & & -0.0032 & & & -0.0037 & \\
\hline & & $(0.003)$ & & & $(0.003)$ & \\
\hline \multicolumn{7}{|l|}{ FDI x Education level } \\
\hline \multicolumn{7}{|l|}{ Base group: Primary or under } \\
\hline \multirow[t]{2}{*}{ Lower secondary high school } & & & -0.0004 & & & -0.0003 \\
\hline & & & $(0.001)$ & & & $(0.001)$ \\
\hline \multirow[t]{2}{*}{ Upper secondary high school } & & & -0.0000 & & & -0.0001 \\
\hline & & & $(0.002)$ & & & $(0.001)$ \\
\hline \multirow[t]{2}{*}{ Tertiary or higher } & & & $-0.0046^{* *}$ & & & $-0.0049 * *$ \\
\hline & & & $(0.002)$ & & & $(0.002)$ \\
\hline \multirow[t]{2}{*}{ Constant } & $8.5080 * * *$ & $8.4998 * * *$ & $8.5132 * * *$ & $8.5790 * * *$ & $8.5814 * * *$ & $8.5975 * * *$ \\
\hline & $(0.587)$ & $(0.598)$ & $(0.594)$ & $(0.461)$ & $(0.470)$ & $(0.466)$ \\
\hline Observations & 971,597 & 971,597 & 971,597 & 971,597 & 971,597 & 971,597 \\
\hline R-squared & 0.399 & 0.399 & 0.399 & 0.399 & 0.399 & 0.399 \\
\hline Other Controls & YES & YES & YES & YES & YES & YES \\
\hline
\end{tabular}

Clustered standard errors at provincial level in parentheses. Province and year fixed effects are included in all models.

$$
* * * \mathrm{p}<0.01, * * \mathrm{p}<0.05, * \mathrm{p}<0.10
$$




\title{
Chapter 4 Vocational Education, Manufacturing Competitiveness, and Income Distribution: International Evidence and Case Studies
}

\begin{abstract}
Economic integration has brought about not only benefits and opportunities but also required adjustment, especially for the youth entering the labour force. The lower growth rates characterizing the post-Global Financial Crisis era and the concerns about income inequality raise the question of how targeted investment in human capital may alleviate the challenges facing the working poor. Using cross-country data, we find the association between the income shares of the working poor, dependence on the manufacturing sector, and the availability of vocational education. As the manufacturing sector increases its share in GDP but reduces its size in terms of employment due to economic recovery, trade, and automation, improved access to better vocational education will probably contribute more towards tackling inequality than a large increase in regular college attainment, if tertiary and vocational are the two main available pathways for students to pursue. Comparing the US to Germany suggests that pushing more students to BA granting colleges may no longer be the most efficient way to deal with the challenges caused by the decline in manufacturing employment affecting lower-income households. We also note that track records of technical training and educational budget, shown in the case of Vietnam in comparison to Thailand, as well as government subsidies for reskilling of labour force throughout their careers in Singapore, are potential explanations for their relative manufacturing competitiveness.
\end{abstract}




\subsection{Introduction}

The Global Financial Crisis (GFC) and the following growth deceleration have increased attention on increasing inequality, and specifically on the declining real incomes of the working poor. The evidence of the increasing inequality is meticulously documented, most notably by Piketty's (2014) now-famous Capital in the $21^{\text {st }}$ Century.

At the same time, the role of education and acquired skills in upward mobility and in generating growth has also been well appreciated (e.g., ILO, 2014. Behar, 2016). The potential for job-related training as a means to achieve growth in incomes and reductions in inequality has also been found (e.g., Attanasio et al., 2017). However, lingering questions remain about the types of educational programs associated with the most effective improvement in incomes at the lower end of the income distribution; and what factors shape the effectiveness of these programs.

This generated a significant debate and disagreement in the 2016 US election. "Free college" was an effective rallying cry for Clinton's primary opponent, Bernie Sanders. At the 2016 Democratic National Convention, Sanders gave a speech endorsing Clinton, in which he said: "We have come together on a proposal that will revolutionize higher education in America. It will guarantee that the children of any family [in] this country with an annual income of $\$ 125,000$ a year or less...will be able to go to a public college or university tuition-free." Clinton herself also backed universal free community college. Both these two proposed programs taken together are estimated to cost half a trillion dollars if phased in over four years (CRFB, 2016). These plans have not been implemented given the election results, but the public debate about the cost of higher education in the United States has certainly not been resolved.

An example of campaign promises that did materialize into real policy is New Zealand. Providing free tertiary education was a key promise in the Labour Party campaign in the 2017 general election, as part of their first 100-day plan. After winning, the Labour-led government rolled out a policy to provide free first-year education for anyone who has done less than six months full-time tertiary education before. The scheme is also expected to increase to two years in 2021 and eventually to full three years in 2024. Estimation shows that it would cost nearly 3 billion New 
Zealand dollars over the first 5 years and would increase the enrolment rate by around 3 percent. ${ }^{38}$ However, in 2020, as part of the effort to restart the economy in recession after the Covid-19 pandemic, the New Zealand government decided to stop the program while at the same time introducing a new scheme of free vocational and apprenticeship training. ${ }^{39}$ It does appear that following pandemic or crisis periods, when there are massive demands for retraining and reskilling to support economic recovery, vocational education may be a better complementary policy.

In this paper, we question the focus on higher education as a suitable accompanying policy for economic recovery, and as a solution to the declining low incomes and increasing inequality problems. With limited resources, what should be the focus of subsided education? Is (nearly) free college education the key to a solution to these problems? Will it likely address the problems of the working poor? We turn to our data to answer these questions.

Using fixed-effect regression and a sample of 24 countries from 1990-2014, we observe a clear pattern and a tentative answer is that improved access to vocational education can probably contribute more towards reducing inequality than large increases in college attainment. More specifically, we confirm an observed quantifiable association between the income shares of the working poor and the availability and take-up of vocational education. For our comparative case study, contrasting the United States and Germany suggests that pushing more students to degreegranting colleges may not be an efficient way to deal with the decline in both manufacturing jobs and consequently real incomes of the working poor. Such policy may induce private and public overinvestment in higher (degree) education by some segments of the population, with little observed economic returns. Before we turn to the evidence (in sections 4.2 and 4.3), we add a few more observations from the literature that has examined the efficacy of vocational training programs in specific countries.

Previous empirical research on vocational training, from LaLonde (1986) onward, has largely focused on specific training programs training the under-employed or unemployed, and more recently usually within the context of randomized control trials (RCT) methodology for treatment identification. Recent examples include Attanasio et al. (2017) which provides a long-term

38 https://www.education.govt.nz/assets/Documents/Ministry/Information-releases/CAB-17-MIN-0515-Minute.pdf Making Tertiary Education More Affordable: Fees-free Education in 2018.

39 https://www.education.govt.nz/our-work/publications/budget-2020/trades-and-apprenticeships-training-package/ Trade and Apprenticeship Training Package. 
analysis of such a program in Colombia, Blattman et al. (2014) which focus on a training program in Uganda, and Card et al. (2011) on youth vocational training in the Dominican Republic. The findings from this literature are mixed, with, not surprisingly, differing levels of efficacy associated with different programs.

More similar to our interest, another strand of the literature has posed the question of whether public policy should prefer more investment in vocational or academic training, but this literature is generally older and also focuses on specific country experiences_e.g., Yang (1998) on China. For example, Moenjak and Worswick (2003), examining individual data from Thailand and using parents' educational attainment to instrument for the choice between general and vocational education, find a financial benefit associated with vocational training. El-Hamidi (2006) considers this choice in Egypt, and arrives at the opposite preference, arguing that general education coupled with on-the-job training provides the highest benefit. Chen (2009) and Newhouse and Suryadarma (2011), using detailed data from the Indonesia household panel survey, find more nuanced differences in the employment outcomes of those who received academic vs. vocational education at the upper-secondary level; and heterogeneities appear to depend on the gender, the cohort and the socio-economic background of the students examined. Malamud and Pop-Eleches (2010), drawing on empirical evidence from Romania, conclude that identified differences between those who pursue the academic versus the vocational track are largely driven by self-selection into these two options, rather than by any impact of the tracks themselves. Meer (2007) finds evidence from US data that accounting for self-selection overturns previous conclusions in favour of vocational tracking.

There are other important factors affecting the mode of education and pattern of inequality. We do not intend to capture all of them in this paper. Students may choose to take up vocational training rather than pursue their passion in university degree of choice because of financial reasons. This can represent a form of inequality in educational access. It is also not clear that denying educational desire at the personal level (e.g. giving up a BA in English to pursue vocational training in healthcare because of the latter's financial advantage) will lead to improved wellbeing, even if increased income materialises.

In the next section, we describe the previously unexamined cross-country evidence which forms the backbone of our analysis, while we discuss some comparative case studies contrasting the US 
with Germany and Thailand with Vietnam in Section 4.3. We end with some concluding remarks in Section 4.4.

\subsection{Cross-Country Evidence}

\subsubsection{Data}

We combine data from several sources. We use the World Wealth and Income Database (Top 10\% Income Share) and OECD and World Bank Database (S80S20, GINI ${ }^{40}$ for measurements of inequality. For measuring manufacturing contribution, international trade, and automation, we use data series from the World Development Indicators: Manufacturing value-added as share of GDP, manufacturing exports as share of merchandise exports, high-technology exports as share of manufactured exports, and trade as percentage of GDP. Data on manufacturing sector employment share is extracted from the International Labour Organization (ILO).

For access to vocational education, we use OECD data on the share of vocational programmes as percentage of upper secondary education, UNESCO and ILO data on the share of youth (15-24 years old) enrolled in vocational education, and Eurostat data for the number of enterprises providing continuing vocational training (CVT) as share of all enterprises, percentage of employees from all enterprises participating in CVT courses, and cost of CVT courses as percentage of total labour cost. The main estimation using our baseline sample includes at most 24 countries, depending on the variables used in estimation, covering the 25 years from 1990 to 2014. Table 4.1 provides a country list and summary statistics; the Eurostat continuing vocational training data is only available for 11 countries, so these constitute our most restricted sample. Table 4.2 presents summary statistics for the baseline sample.

For inequality, we observe a wide variation across measures and countries (Table 4.1). The top $10 \%$ income share ranges from $14.6 \%$ in Mauritius to $61.0 \%$ in South Africa, with a standard deviation of $6.9 \%$ for the full 24-countries sample. Our sample can increase to 65 countries when we examine the S80S20 and Gini data, however, the time dimension drops to only 16 years. As our fixed-effects estimation mainly relies on the within variation over time, we decide to use the

\footnotetext{
${ }^{40}$ The top $20 \%$ /bottom $80 \%$ income ratio and the $90 / 10$ quintile ratio, respectively.
} 
top income share of $10 \%$, as it covers the longest period. ${ }^{41}$ Moreover, these three measures are very highly correlated in 24 countries constitutes our baseline sample, so it is of little importance which of the three is used in the regressions described below. ${ }^{42}$

According to all three inequality measures in our baseline sample, the most unequal countries are South Africa, Uruguay, Russia, Japan, Spain, and the United Kingdom, while the most equal ones are the Scandinavian countries, the Netherlands, and Germany (the United States is not included because of the lack of vocational training data).

On the size of the manufacturing sector, China has the largest in our sample (31.6\% of GDP), while Norway has the smallest (8.9\%). According to Deloitte $(2010,2013,2016)$, four of the biggest five manufacturing countries worldwide are in our sample: China, Germany, Japan, and the United Kingdom. We also include measures of exports, and the variability in this measure is very high: Some countries hardly export any manufacturing like Australia, New Zealand, Norway, while others export almost exclusively manufacturing like Korea or Japan. There is similar variability in the amount of high-tech exports, and the total trade to GDP ratio.

On the share of vocational education, Netherlands has the highest indicator (68.3\%), while South Africa has the lowest (8.9\%). As we noted previously, South Africa has the highest top $10 \%$ income share, and the lowest share of vocational education, while the Netherlands has almost the opposite. The pairwise correlations between measures of vocational share and measure of inequality (top $10 \%$ income share) are always negative. They are around -0.27 for the share of vocational education in upper secondary education, -0.5 for the share of continuing vocational training (CVT) enterprises, -0.41 for the share of CVT employees, and -0.46 for the CVT costs as a percentage of total labour cost. These preliminary observations provide motivations for our detailed analysis below.

\subsubsection{Empirical Specification}

Due to data availability, most of our panel regressions are unbalanced with some missing observations over time. Our baseline regressions contain 24 countries from 1990 to 2014 with the

\footnotetext{
${ }^{41}$ We also estimate our model using the largest possible sample in terms of observations for robustness check.

${ }^{42}$ The correlation coefficient between the first two measures in 0.97 , while between the second two measures the correlation is 0.92 .
} 
total number of observations ranging from 260 to 276 across specifications. We use two-way fixedeffects estimation for all models:

$$
\text { Inequal }_{i t}=\alpha+\beta \text { manu }_{i t}+\gamma \text { vet }_{i t}+\delta\left(\text { manu }_{i t} * \text { vet }_{i t}\right)+\mu_{i}+\theta_{t}+\varepsilon_{i t}
$$

where $\alpha, \beta, \gamma, \delta$ denote parameters for estimation; Inequal ${ }_{i t}$ is inequality measure, manu $_{i t}$ is the manufacturing contribution or exports measure, vet $_{i t}$ is vocational share measure for country $i$ at time $t ; \mu_{i}$ is the country fixed-effects, $\theta_{t}$ is year dummies and $\varepsilon_{i t}$ is the vector of regression residuals (assumed iid). The country fixed-effects control for unobservable country-specific structural characteristics while the time dummies can factor out the impact of common time-specific shocks such as the Global Financial Crisis.

Table 4.3 reports coefficient estimates for equation (1). We find that both the relative size of the manufacturing sector, trade integration, and the share of vocational education are positively associated with the top $10 \%$ income share. In a standard trade model, both terms-of-trade adjustment and skilled-bias technological change can give rise to increasing inequality. However, interestingly, we find that an interaction between the relative size of the manufacturing sector or export share, and the share of vocational education is negatively associated with the top $10 \%$ income share. As the manufacturing sector becomes more important in a country's income, relatively unskilled labours benefit from access to vocational education, thereby narrowing the income gap with skilled labours. The mechanism behind this correlation is: as continuous technological advance transforms the manufacturing sector, the remaining jobs which cannot be replaced by machine would require higher degrees of compatibility with modern technology. Vocational skill-based education would be more suitable to prepare students for this. Alternative specifications using manufacturing shares in exports and high-tech shares in total exports provide the same qualitative results.

As countries continue their recovery from the Global Financial Crisis, it is expected that the manufacturing sector may increase its importance in total income. Figure 4.1 shows that after sharp contractions around 2007-2009, the percentages of manufacturing value-added in GDP have been increasing in several countries in our baseline sample. We can also expect a similar trend in the near future following the Covid-19 pandemic shock. However, with the speed of technological progress, specifically automation, and globalization, there is no guarantee that these increases in value are accompanied by more manufacturing jobs. In fact, Figure 4.2 shows that even during the 
recovery period after the GFC, manufacturing employment share continued its downward trend in many countries. In the next estimation, we include manufacturing employment share and its interaction with access to vocational education in our model to explicitly account for these two contradicting trends in the manufacturing sector. Table 4.4 presents the results, using share of vocational education in upper secondary education (column 1) and share of youth (15-24 years old) enrolled in vocational education (column 2). The signs of the interaction terms mean that as manufacturing value increases and manufacturing employment decreases, which is what we expect to happen going forward, improving access to vocational education can reduce income inequality. We provide a numerical example based on the variation in our data from Table 4.4. From column 1 , the marginal effect of vocational share on the income share of top $10 \%$ is:

$$
\frac{\delta \text { Inequal }}{\delta \text { vet }}=0.11-0.017 * \text { manu }+0.009 * \text { manu_employment }
$$

As manufacturing value share increases by one standard deviation, i.e. 5.98 percent and manufacturing employment share decreases by one standard deviation, i.e. 4.67 percent, the marginal effect of vocational share on inequality would equal to $0.11-0.017 * 5.98+0.009 *(-4.67)$ $=-0.03$. More specifically, one standard deviation increase in vocational share, or 18 percemt in our sample, is associated with 1.7 percent decrease in the income share of the top $10 \%$, all else equal. $^{43}$

Figure 4.3 illustrates the marginal effects of vocational share on inequality for three different levels of manufacturing's contribution (low, medium, and high corresponds to the $25^{\text {th }}, 50^{\text {th, }}$ and $75^{\text {th }}$ percentile in the respective sample), according to our baseline results in Table 4.3. Specifically, at low level of manufacturing contribution, increasing vocational share is correlated with either an increase or only a small reduction in inequality, ceteris paribus. However, as manufacturing increases its relative share in the economy, incremental improvement in vocational education's access for students is associated with a significantly larger decline in inequality. Together with the decreasing trend of manufacturing employment shown in Figure 4.2 due to trade and automation, this may suggest that vocationally trained workers are more compatible with modern manufacturing than workers with tertiary education, and therefore skill mismatch can be better avoided. Finally, the alternative measures of educational access to vocational training — share of

\footnotetext{
${ }^{43}$ This is calculated by $-0.03 * 18 / 33$ where $33 \%$ is the average income share of top $10 \%$ in our sample.
} 
vocational education in upper education, the cost of vocational training, share of youth (15-24 years old) enrolled in secondary education —all yield consistent results with our main findings. ${ }^{44}$ Table 4.5 presents our results using data from Eurostat's Continuing Vocational Training Survey to proxy for vocational share in education. Even though this is a more direct and potentially more suitable measure, it is only available for the year 2010. The small sample size thus requires us to be extra cautious when interpreting our results. Regression results using 11 European countries in which we have data for CVT measures - vocational training as percentage of labour cost (row 4), share of employees participated in vocational training (row 5) and share of enterprises providing vocational training (row 6) - are generally consistent with previous results. The estimated interaction coefficients are negative and strongly significant in most of the specifications which provide strong evidence for the impact of vocational education access on income inequality as a complementary policy for economic recovery and trade adjustment.

Table 4.6 provides coefficient estimates using alternative measures of inequality, including the S80S20 - the ratio of average income between the richest $20 \%$ and the poorest $20 \%$, and the Gini coefficient. As we have previously observed that these measures of inequality are highly correlated in our sample, these robustness checks are largely supportive of the baseline estimates. There is less variation in other measures of inequality relative to the top $10 \%$ income share (as shown in the summary statistics), but the effects of the manufacturing sector and share of vocational education remain statistically significant for S80S20, and the Gini coefficient. One notable difference is the regression using manufacturing share of GDP (columns 1 and 6), in which the estimated coefficients for all three covariates have opposite signs compared to the baseline results. However, in both these regressions, the number of years covered and the number of total observations are only half of those in our main specifications in Table $4.3{ }^{45}$ Therefore, these inconsistencies can be explained by the sample bias resulting from the randomness of the missing data.

In Table 4.7, we extend our robustness test to include all countries with available data for the S80S20 ratio and Gini coefficient. Our sample, therefore, increases to 65 countries; however, the

\footnotetext{
${ }^{44}$ These results are consistent with micro-econometric case studies - e.g., Moenjak and Worswick (2003) for Thailand, and Attanasio et al. (2011 and 2017) for Colombia.

4512 years and 146 observations versus 25 years and 270 observations.
} 
time dimension reduces to only around 16 years, from 1998 to 2013. Overall, our results remain largely robust with the extended sample. The main variable of interest, estimated interaction between manufacturing contribution and vocational education share, are negative and strongly significant in most specifications. The use of manufacturing share in GDP, manufacturing share in exports, or high-tech manufacturing share of exports does not affect the qualitative results.

\subsection{Case Studies}

\subsubsection{Germany versus USA}

The post-GFC labour market dynamics in the United States put to the fore the decline in manufacturing employment. A narrative gaining political momentum (and the presidency) has been that US manufacturing employment decline is the outcome of globalization. Accordingly, NAFTA, the WTO, and other trade agreements, and the sizable current account deficits of the US were the key drivers for the decrease in manufacturing employment. In contrast, according to this narrative, China and Germany are prime examples of countries benefiting from globalization. This section reflects on these arguments, focusing on the contrast between Germany and the USA.

To put these claims in the longer-term perspective, we look at Figure 4.2 which reports the manufacturing employment shares, 1970-2012, vividly showing that the trend decline in manufacturing employment is common to both Germany and the US. While Germany's level of manufacturing employment remains well above that of the US - higher by 13 percent in 1970 and about 10 percent in 2012 - both countries experienced continuing employment declines, at an annual rate of loss of 0.47 percent in Germany, and 0.38 percent in the US. Indeed, similar trends apply across other OECD countries, and even beyond the high-income countries to many emerging markets. $^{46}$

Figure 4.4 provides relevant information on the main driving factor, reporting the manufacturing value-added/GDP for Germany and the US during 1997-2015. Remarkably, in Germany, despite the decline in manufacturing employment share, the manufacturing GDP value-added share has been stable, at about 23 percent, and recovering fully after a $\mathrm{V}$ shape adjustment during and after

\footnotetext{
${ }^{46}$ Globalization, thus, does not appear to be a zero-sum game of winners and losers in the struggle for trade. It is hard to see how globalization can explain the almost universal declines in manufacturing employment.
} 
the GFC. In contrast, during the past two decades, the US experienced a drop of about 5 percent in the manufacturing value-added while the manufacturing employment share dropped by $6 \%$.

These trends are in line with the view that technological changes or increasing automation were the key drivers affecting both the US and Germany, and Germany's overall superiority in labour productivity was the reason behind these differing outcomes. Figure 4.5 reports the index of real Unit Labour Costs in the Manufacturing Sector, which indicates the competitiveness of the manufacturing sector ${ }^{47}$ from 1992-2016. The chart is consistent with the greater performance of the manufacturing sector in Germany relative to the US: the real unit labour cost in the US dropped by about $10 \%$ in 20 years, while it has been largely constant for Germany

The differential manufacturing performance of these two countries may be the outcome of structural factors, as well as policies. While we cannot pin down a causal interpretation, we note several structural differences between these countries that we think are important. The educational attainment statistics of the two countries differ sharply. The labour force in Germany is relatively more replete with workers with upper-secondary education, while the labour force in the US is more loaded with those who have tertiary education credentials. The share of workers with upper secondary in Germany exceeds that of the US by about 15 percentage points and the share of workers with tertiary education in the US exceeds that of Germany by about 17 percentage points (Table 4.8). On its face, therefore, the US labour force is more educated or more highly skilled.

Another noteworthy difference is the design of public policies in general and more specifically the patterns of inequality and redistribution. The safety net in Germany is deeper and wider than in the US, covering more people and with more resources, and the income inequality in the US is substantially higher than that in Germany using S8020 and Gini measures (Table 4.8). Given the relative success of German manufacturing value-added in recent decades, it is likely that Germany's education system fits better the needs of modern manufacturing. It is likely that modern manufacturing requires more upper-secondary and vocationally trained labour rather than more workers with tertiary academic education.

\footnotetext{
${ }^{47}$ It is because if labour cost is below productivity, firms can hire more to maximize profit. In contrast, when labour cost exceeds productivity, firms may start laying off employee to cut cost.
} 
The public policy concern about over-investment in four-year colleges in the US largely concentrates on the newer for-profit and online sectors (e.g., Deming, Goldin, and Katz, 2012). Yet, the rise in the cost of college educations at rates that are out of line with the expected employability and the financial return associated with college education are found in all the different components of the tertiary education system - from two-year public institutions that are the cheapest, to the four-year private non-profits that are generally the most expensive and show the lowest return on investment. The very large system of tertiary education in the US is very heterogeneous, but it puts the main emphasis on the four-year college system (both private and public, and for-and non-profit).

Other concerns, beyond escalating costs and overinvestment, are the limited information available to students regarding the alternatives available to them. There are also concerns about the information regarding co-funding with federally subsidized loans, which allows many colleges to survive despite delivering a low-quality education with clearly negative financial returns. These funding models saddle the working poor with high debt burdens that appears unjustified by the low return on their investment.

The total outstanding student loan debt in the U.S. is US\$ 1.2 trillion, the second-highest level of consumer debt, only behind mortgages. It is reported that about 40 million Americans hold student loans and about $70 \%$ of bachelor's degree recipients graduate with debt. One in four student loan borrowers is either in delinquency or default on their student loans, according to the Consumer Financial Protection Bureau. ${ }^{48}$ These facts are consistent with the mismatch hypothesis - there are too many four-year colleges serving too many students, and too few institutions with greater focus on vocational education and training. This mismatch is sustained by the skewed assistance scheme that is facilitated by the federal government. A Brookings study by Looney and Yannelis (2015) reveals that a large share of the growth in the number of students struggling to pay off their student loans is from students borrowing to attend for-profit schools. These public policy concerns are magnified by the fact that student debt in the US is even harder to walk away from than mortgage or credit card debt as it is not erased if one declares bankruptcy. Hence, the impact of a student debt crisis would be exceptionally pernicious and damaging.

\footnotetext{
48 https://www.marketwatch.com/story/americas-growing-student-loan-debt-crisis-2016-01-15 An overview of the heterogeneity of the US college system can be found in http://nces.ed.gov/programs/coe/indicator_csa.asp.
} 
While manufacturing employment share has declined substantially in both countries, the shallower safety net in the US may explain why this issue has generated a greater social impact in the US than in Germany. The first-ever decline in life expectancy in some parts of the US, and the growing despair of the displaced less-educated workers in the US, identified by Case and Deaton (2015 and 2017), probably reflects these shallower safety nets. It may resemble more the dynamics in Russia after the collapse of the Soviet Union and its own de-industrialization, rather than the dynamics observed in Germany. ${ }^{49}$

The vocational employment training (VET) in Germany is much more developed. The CESifo database on Institutional Comparisons in Europe (DICE) includes a lot of institutional detail about the VET found in many European countries (and where the data is available, also the US). ${ }^{50}$ For example, Germany starts identifying students who are struggling in the 'academic' track in middle school ( $7^{\text {th }}$ grade) and has various mechanisms in place to assist these students to succeed in VET programs, while in the US, any assistance that is available, is only for students once they drop out of a 'normal' high-school, and can get assistance to receive a GED (a certificate that is considered equivalent to completing high-school). Vocational training even after that (post-secondary) is still rare and is almost only found if it is organised privately for specific professions.

Rebalancing the post-secondary education system in the US with more vocational training may not be a panacea. Notably, Hanushek et al. (2017) concluded that vocational education is harmful in the later phases of work careers - vocationally qualified workers are the first to be laid off after the age of 50 because their specific skills are likely to be outdated. However, Forster et al. (2016) noted that, while it may be true that people with vocational qualifications are less likely to be employed later in their career, this pattern may be conditional on the way that vocational education is organized. Specifically, they argue that the warning of Hanushek et al. (2017) to the proponents of a German-style vocational training system should imply that the late-career disadvantage of vocational degrees would be more pronounced in countries with a large dual system (i.e., work and school-based). However, looking at the data, they did not find evidence of that difference. On the contrary, German-like education systems with a strong emphasis on dual tracks are

\footnotetext{
${ }^{49}$ Germany had its fair share of socially costly dislocation associated with the unification of East and West Germany. The contrasting dynamics between the US and Germany validate Rodrik (2011)'s conjecture that deeper safety is conducive towards smoother globalization and the adjustment to new technologies.

${ }^{50}$ http://www.cesifo-group.de/ifoHome/facts/DICE/Labour-Market/Labour-Market/Training.html.
} 
characterized by less disadvantage late in the careers of vocationally qualified workers. The negative effect of vocational training at the end of the career are observable statistically only in countries that do not have dual-track systems, like the United States and Canada.

In summary, overlooking the need to align the education system with the demands of the real economy comes with growing personal and social costs. We close this case study by noting that the US mortgage debt crisis of 2008-2010, and the education debt overhang in the US may both be indicative of structural differences that led to over-investment in both real estate and in college education in the US relative to Germany. ${ }^{51}$

\subsubsection{Thailand versus Vietnam}

Thailand and Vietnam are middle-income countries striving for export-led manufacturing success in global markets. ${ }^{52}$ According to the Global Manufacturing Competitiveness report (Deloitte, 2016), they are, together with Indonesia, Malaysia and India, have been considered the "Mighty Five" or the potential substitutes for China in terms of new manufacturing hubs. For the past three decades, cheap labour, favourable demographics characteristics, and proximity to Japan, Korea, and China have contributed to their performances in manufacturing exports. The past decade, however, saw even cheaper labour, from other middle-income countries, eroding the comparative advantage of both Thailand and Vietnam, while the learning-by-doing increasing returns dynamics that are sometimes associated with participation in global supply chains has proved to be rather elusive for these two emerging economies. ${ }^{53}$

Figures 4.6 illustrates the structure of the educational system in Thailand and Vietnam. With regards to the technical and vocational training, an earlier start of tracking and differentiation in Vietnam (lower secondary) than in Thailand (upper secondary) is a notable difference. For Thailand, the vocational programs are under the Ministry of Education, while Vietnam legislated

\footnotetext{
${ }^{51}$ This over-investment may reflect structural factors such as the differential use in leverage in funding housing and education services in the two countries, the differential tax system, and the greater role of private and for-profits education in the US (see Aizenman and Noy, 2012).

52 According to the World Bank's Development Indicators, in 2015, GDP per capita in Thailand was almost USD 6000, while in Vietnam it was about USD 2100.

${ }^{53}$ At least partially, this difficulty is deeply rooted in the political challenges Thailand and Vietnam are facing. The former is currently ruled by the military, following a coup in 2014, the latter is under the absolute rule of the Vietnam Communist Party.
} 
its two institutions (Ministry of Education and Training, and Ministry of Labour-Invalids and Social Affairs) to oversee the technical training. ${ }^{54}$ In both countries, there is a lack of micro-level evidence on the effectiveness of vocational training. The preference for university education in both countries also stigmatizes the acquisition of vocational certification and reduces the desirability of vocational degrees. This, of course, implies that those who self-select into the vocational track may do so not out of a preference but because the academic track is closed for them. Consequently, if academic performance might be considered as positively correlated with ability and earning potential, these vocational graduates would end up with lower income and therefore even worsen public perceptions on vocational education. On the other hand, in both countries, low quality of training and lack of harmonized skill accreditation system also prevented vocational qualifications from being sufficiently recognized by employers. Together with poor public perception, these inadequate recognitions have contributed to the relatively low enrolment rate of vocational education at all levels in both countries.

The contrasts between Thailand and Vietnam are noticeable in the budget allocation for education. Both countries spent close to 5 percent of GDP on education, similar to more advanced economies such as Germany and the United States. Yet, as shown in Figures 4.7 (upper) and 4.7 (lower), Vietnam allocated almost 20 percent of the education budget on upper-secondary education (vocational training included), while Thailand expensed only 10 percent for the upper-secondary level. ${ }^{55}$

In terms of the institutional framework, only Vietnam has issued the Law of Vocational Training in 2006, which has been continuously reviewed and revised. Since its adoption, the law has substantially improved the management of vocational education and its quality in Vietnam (Bussi et al., 2016). Perhaps its investment in vocational training and institutional difference help explain the forecast that Vietnam is about to overtake Thailand for its global manufacturing competitiveness ${ }^{56}$.

\footnotetext{
${ }^{54}$ However, since January 2017, vocational education's management has been fully transferred to the Ministry of Labour, Invalids and Social Affairs in Vietnam.

${ }^{55}$ According to Vietnam Vocational Training Report 2013-2014, on average, expenditure on vocational education \& training accounts for approximately $7.9 \%$ of Vietnam's total government expenditure during this period (around $40 \%$ of total education budget.)

${ }^{56}$ Younger labour force as well as more competitive unit labour cost in manufacturing might also partially contribute to this forecast. Latest Labour Force survey in both countries reveal that youth (age 15-24) account for 10.6\% and
} 
Figures 4.8 provides the level of manufacturing competitiveness together with some underlying factors. Based on the survey of CEOs by Deloitte (2010, 2013, 2016), by the next decade, Vietnam is expected to rise from the $18^{\text {th }}$ to be the $12^{\text {th }}$ among the top manufacturing exporters globally, overtakes Thailand in the $14^{\text {th }}$ place.

Currently, not enough data is available to determine if indeed Vietnam's additional investment in technical and vocational training, and its add-on effects to the manufacturing sector, would eventually translate into lower income inequality in Vietnam (and to a lesser extent in Thailand). Currently, the richest 20 percent have more than 40 percent of national income in both countries. As shown in Figures 4.9, the gap between the top 20 percent and the bottom 20 percent ${ }^{57}$ has been relatively lower for Vietnam over the past three decades. Access to vocational training may be an important component of a possible strategy for reducing this inequality. However, more microfound evidence in the future would be needed to back this claim.

\subsection{Conclusions}

Labour-saving technological innovations probably account for the decline in manufacturing employment share more than international trade. The declining employment share in manufacturing resembles the earlier collapse of employment share in agriculture, though the speed of the adjustment has accelerated substantially. As information technology, automation, and more recently artificial intelligence impact more sectors, there is as yet no evidence that the new disruptive technologies will open up new lines of employment at a rate that will be sufficient to compensate for the disappearance of employment in old industries (Acemoglu and Restrepo, 2017). Furthermore, it is not clear that the skills required for these new jobs will be matched with those workers whose jobs disappeared. This renewed need for better matching of skills between workers and new jobs will most definitely be affected, to a certain extent, by the quantity and quality of vocational training available in each country. It is this vocational training that we see as playing a central role in determining the outcomes for the low-skilled, low-wage, workers that

$15 \%$ of the total labour force in Thailand and Vietnam, respectively. In addition, Thailand's unit labour cost in manufacturing is approximately $40 \%$ higher than in Vietnam (Deloitte, 2016)

${ }^{57}$ The relative ratio between the green bar (top 20\%) and the orange bar (bottom 20\%) 
populate the lower part of the income distribution. It is thus this vocational training that can have a large reduction impact on income inequality.

The quantitative evidence on the role of vocational training is imperfect, but both the limited crosscountry evidence analysed here, and the comparisons we made convinced us that well-resourced and well-targeted vocational training can prove to be a better long-term investment in skill acquisition and can assist in ameliorating the difficulties faced by workers whose jobs are currently disappearing and whose prospects look, in many cases, to be quite bleak.

A key challenge for the countries on the technological frontier will therefore be to provide this vocational training and re-training that will hopefully prevent the jobless future for many. Failing to do this, countries will either have to rapidly upgrade their safety net to avoid increasing destitution, or to face the consequences of greater political instability and increasing social costs associated with the hollowing-out of the middle class. This political instability is likely to be the reason for such anomalies as the Brexit vote, the US election of 2016, and other recent electoral surprises.

An example of governments playing a very active role in vocational education is Singapore. Since 2016, the Singaporean government has subsidised any training courses (currently about 9,000) from educational providers, including universities and online learning, for SGD500 to Singaporean workers above the age of 25 , and up to $90 \%$ for workers above the age of 40 (The Economist, January 12, 2017). While Singapore is known for its entrepot and manufacturing economy, this type of government program has the potential to help reskill and protect workers from adverse trade effects and adjustment in the global competitive market landscape.

In the future, we hope to work on extensions that will examine: (i) the importance of vocational training in the service sectors, to see whether similar patterns emerge, (ii) more detailed accounting of the quality of vocational and college education, and (iii) the impact of vocational training on poverty. 


\section{Figures and Tables}

Table 4.1 Country list and summary statistics - Baseline sample

\begin{tabular}{|c|c|c|c|c|c|c|c|c|c|c|c|c|c|}
\hline Country & Top $10 \%$ & S80S20 & P90P10 & GINI & Manu/GDP & Manu/EXP & $\begin{array}{c}\text { High- } \\
\text { tech/EXP }\end{array}$ & Trade/GDP & $\begin{array}{l}\text { VET } \\
\text { share }\end{array}$ & $\begin{array}{l}\text { youth } \\
\text { VET }\end{array}$ & $\begin{array}{l}\text { CVT } \\
\text { Ent }\end{array}$ & $\begin{array}{c}\text { CVT } \\
\text { employ }\end{array}$ & $\begin{array}{l}\text { CVT } \\
\text { cost }\end{array}$ \\
\hline Australia & 29.7 & 5.9 & 4.4 & 34.3 & 10.6 & 23.6 & 12.9 & 40.9 & 56.2 & 10.8 & & & \\
\hline China & 37.7 & 9.3 & 7.6 & 46.9 & 31.6 & 92.2 & 25.5 & 50.0 & 45.1 & & & & \\
\hline Denmark & 25.7 & 4.3 & & 27.5 & 15.0 & 64.4 & 18.9 & 87.3 & 53.4 & 14.5 & 91.0 & 37.0 & 1.8 \\
\hline Finland & 31.1 & 4.0 & 3.0 & 26.3 & 25.0 & 83.2 & 21.9 & 73.8 & 55.1 & 17.3 & 74.0 & 40.0 & 1.4 \\
\hline France & 30.7 & 5.0 & 3.6 & 31.6 & 13.3 & 79.6 & 22.3 & 53.9 & 50.2 & 16.6 & 76.0 & 45.0 & 2.5 \\
\hline Germany & 37.9 & 5.0 & 3.5 & 31.2 & 22.4 & 84.3 & 16.1 & 70.4 & 58.5 & 19.0 & 73.0 & 39.0 & 1.5 \\
\hline Ireland & 36.3 & 5.2 & 3.9 & 31.9 & 21.7 & 85.3 & 30.1 & 155.2 & 33.1 & 6.9 & & & \\
\hline Italy & 33.2 & 6.1 & 4.3 & 33.0 & 18.1 & 86.4 & 8.0 & 49.2 & 49.4 & 16.3 & 56.0 & 36.0 & 1.1 \\
\hline Japan & 40.7 & 5.4 & 5.2 & 32.9 & 21.5 & 91.8 & 23.0 & 24.7 & 24.7 & 6.5 & & & \\
\hline Korea & 39.1 & & & & 28.4 & 90.2 & 30.5 & 77.0 & 29.8 & 8.1 & & & \\
\hline Malaysia & 24.0 & 11.3 & & 46.3 & 26.7 & 72.5 & 52.0 & 182.7 & 15.4 & 3.1 & & & \\
\hline Mauritius & 14.4 & & & & 21.4 & 68.7 & 2.5 & 119.8 & 12.6 & 3.3 & & & \\
\hline Netherlands & 30.0 & 4.6 & & 29.4 & 13.7 & 60.3 & 27.1 & 126.5 & 68.3 & 23.7 & 79.0 & 39.0 & 2.2 \\
\hline New Zealand & 31.3 & & 4.2 & 32.8 & 13.1 & 23.5 & 9.8 & 58.0 & 29.6 & 5.7 & & & \\
\hline Norway & 29.2 & 4.2 & 2.9 & 27.5 & 9.6 & 19.9 & 16.8 & 70.7 & 56.6 & 19.8 & 97.0 & 46.0 & 1.7 \\
\hline Portugal & 36.9 & 7.1 & 5.4 & 38.4 & 16.4 & 83.4 & 7.0 & 63.4 & 27.8 & 7.0 & 65.0 & 40.0 & 1.9 \\
\hline Russian & 46.8 & 8.1 & 5.9 & 41.0 & 16.0 & 17.6 & 9.7 & 52.5 & 46.6 & & & & \\
\hline Singapore & 40.9 & & & & 22.1 & 73.7 & 47.6 & 400.4 & 11.2 & & & & \\
\hline South Africa & 61.0 & 27.2 & & 63.2 & 14.3 & 48.4 & 5.1 & 61.1 & 8.9 & & & & \\
\hline Spain & 34.1 & 6.5 & 4.8 & 33.8 & 15.6 & 75.3 & 6.8 & 55.2 & 39.1 & 6.8 & 75.0 & 48.0 & 1.6 \\
\hline
\end{tabular}




\begin{tabular}{lccccccccccccc} 
Sweden & 29.8 & 4.0 & 3.2 & 26.9 & 20.1 & 78.4 & 16.0 & 83.4 & 53.4 & 17.3 & 87.0 & 47.0 & 1.7 \\
Switzerland & 32.2 & 5.5 & & 33.5 & 19.4 & 89.2 & 23.6 & 100.5 & 65.1 & 20.4 & \\
United Kingdom & 40.8 & 6.0 & 4.4 & 35.4 & 11.9 & 74.0 & 26.3 & 54.1 & 30.9 & 12.5 & 80.0 & 31.0 & 1.1 \\
Uruguay & 49.9 & 10.7 & & 45.8 & 16.2 & 25.8 & 6.2 & 52.5 & 29.1 & 6.8 & \\
\hline
\end{tabular}




\section{Table 4.2 Summary statistics - baseline sample}

\begin{tabular}{lccc} 
Variables & count & mean & sd \\
\hline Income share of top 10\% & 465 & 33.283 & 6.890 \\
Income share ratio S80S20 & 170 & 7.090 & 4.134 \\
Gini index (World Bank estimate) & 170 & 35.838 & 7.873 \\
P90/P10 inequality index (OECD) & 118 & 4.645 & 6.967 \\
\hline Manufacturing, value added (\% of GDP) & 613 & 18.997 & 5.983 \\
Manufactures exports (\% of merchandise exports) & 628 & 67.085 & 23.753 \\
High-technology exports (\% of manufactured exports) & 617 & 18.767 & 13.250 \\
Trade (\% of GDP) & 644 & 86.183 & 69.412 \\
Manufacturing employment share (\%) & 589 & 17.198 & 4.675 \\
\hline Share of vocational program in upper secondary education (\%) & 332 & 41.427 & 18.106 \\
Share of youth (15-24y) enrolled in secondary vocational education (\%) & 356 & 13.519 & 7.158 \\
Training enterprises as \% of all enterprises & 297 & 77.545 & 10.976 \\
Percentage of employees participating in CVT courses & 297 & 40.727 & 5.019 \\
Cost of CVT courses as \% of total labour cost (all enterprises) & 297 & 1.682 & 0.405 \\
\hline
\end{tabular}


Table 4.3 Baseline results

\begin{tabular}{|c|c|c|c|c|c|c|c|c|}
\hline \multirow[t]{2}{*}{ Independent variables } & \multicolumn{8}{|c|}{$\begin{array}{c}\text { Dependent variable: } \\
\text { Income shares of top } 10 \%\end{array}$} \\
\hline & Model 1 & Model 2 & Model 3 & Model 4 & Model 5 & Model 6 & Model 7 & Model 8 \\
\hline Manufacturing/GDP & $\begin{array}{c}.78611 \\
(.10942)^{* * *}\end{array}$ & & & & $\begin{array}{c}.75059 \\
(.08236)^{* * *}\end{array}$ & & & \\
\hline Manufacturing/Export & & $\begin{array}{c}.11190 \\
(.04276)^{* * *}\end{array}$ & & & & $\begin{array}{l}-.04262 \\
(.03565)\end{array}$ & & \\
\hline High-tech/Export & & & $\begin{array}{c}.19597 \\
(.06499)^{* * *}\end{array}$ & & & & $\begin{array}{l}.07204 \\
(.04919)\end{array}$ & \\
\hline Trade/GDP & & & & $\begin{array}{c}.05762 \\
(.01766)^{* * * *} \\
\end{array}$ & & & & $\begin{array}{c}.06930 \\
(.01589) * * * \\
\end{array}$ \\
\hline Vocational share in upper secondary & $\begin{array}{c}.16623 \\
(.04731)^{* * * *}\end{array}$ & $\begin{array}{c}.06627 \\
(.05502)\end{array}$ & $\begin{array}{c}.00864 \\
(.02524)\end{array}$ & $\begin{array}{l}-.01222 \\
(.03143)\end{array}$ & & & & \\
\hline Ratio of youth enrolment in vocational & & & & & $\begin{array}{c}.43249 \\
(.09542)^{* * *}\end{array}$ & $\begin{array}{c}.16776 \\
(.06977)^{* *}\end{array}$ & $\begin{array}{l}.04762 \\
(.05917)\end{array}$ & $\begin{array}{l}.04032 \\
(.06743)\end{array}$ \\
\hline Interaction term & $\begin{array}{c}-.01139 \\
(.00257)^{* * *}\end{array}$ & $\begin{array}{c}-.00152 \\
(.00072)^{* *} \\
\end{array}$ & $\begin{array}{c}-.00390 \\
(.00140)^{* * *}\end{array}$ & $\begin{array}{l}-.00039 \\
(.00049)\end{array}$ & $\begin{array}{c}-.02868 \\
(.00593)^{* * *}\end{array}$ & $\begin{array}{c}-.00338 \\
(.00110) * * *\end{array}$ & $\begin{array}{l}-.00525 \\
(.00342)\end{array}$ & $\begin{array}{l}-.00129 \\
(.00114)\end{array}$ \\
\hline R-squared & .378 & .271 & .277 & .298 & .521 & .393 & .363 & .417 \\
\hline Time fixed effects & $\mathrm{X}$ & $\mathrm{X}$ & $\mathrm{X}$ & $\mathrm{X}$ & $\mathrm{X}$ & $\mathrm{X}$ & $\mathrm{X}$ & $\mathrm{X}$ \\
\hline Country fixed effects & $\mathrm{X}$ & $\mathrm{X}$ & $\mathrm{x}$ & $\mathrm{x}$ & $\mathrm{x}$ & $\mathrm{X}$ & $\mathrm{X}$ & $\mathrm{x}$ \\
\hline Number of countries & 24 & 24 & 24 & 24 & 20 & 20 & 20 & 20 \\
\hline Number of years & 16 & 16 & 16 & 16 & 24 & 24 & 24 & 24 \\
\hline Number of observations & 260 & 262 & 262 & 262 & 272 & 276 & 276 & 276 \\
\hline F-statistic & 184.553 & 177.491 & 168.500 & 169.820 & 141.504 & 95.873 & 95.861 & 92.025 \\
\hline
\end{tabular}

Note: Two-way fixed-effects estimations. ***,**, * denotes statistically significance at 1, 5, 10 percent. Countries included: AUS, CHN, CHE, DEU, DNK, ESP, FIN, FRA, GBR, IRL, ITA, JPN, KOR, MUS, MYS, NLD, NOR, NZL, PRT, RUS, SGP, SWE, URY, ZAF. Years covered but with some missing observations: $1990-2014$. 


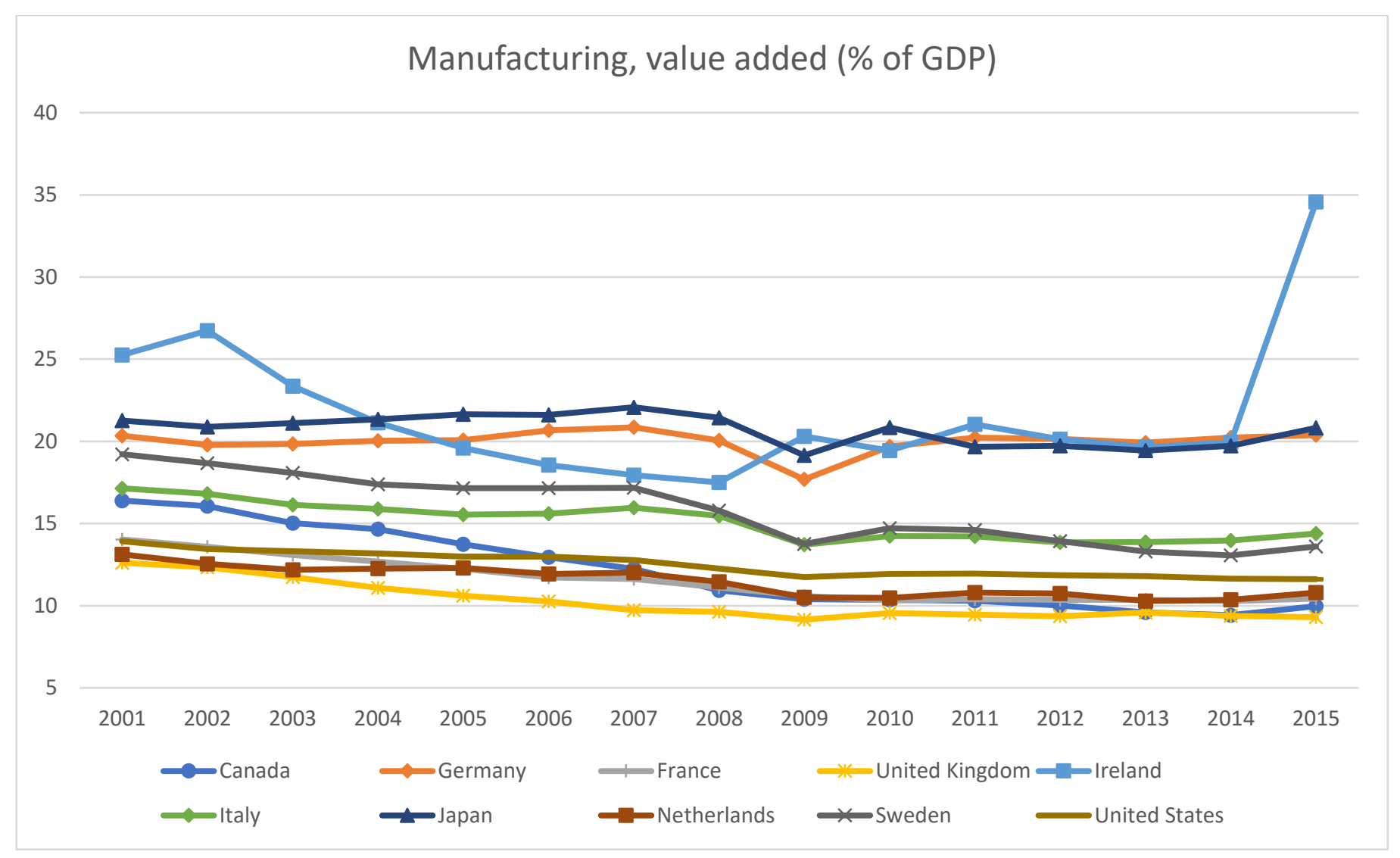

Figure 4.1 Manufacturing value share (\%), 2000-2015

Source: World Bank's World Development Indicator 


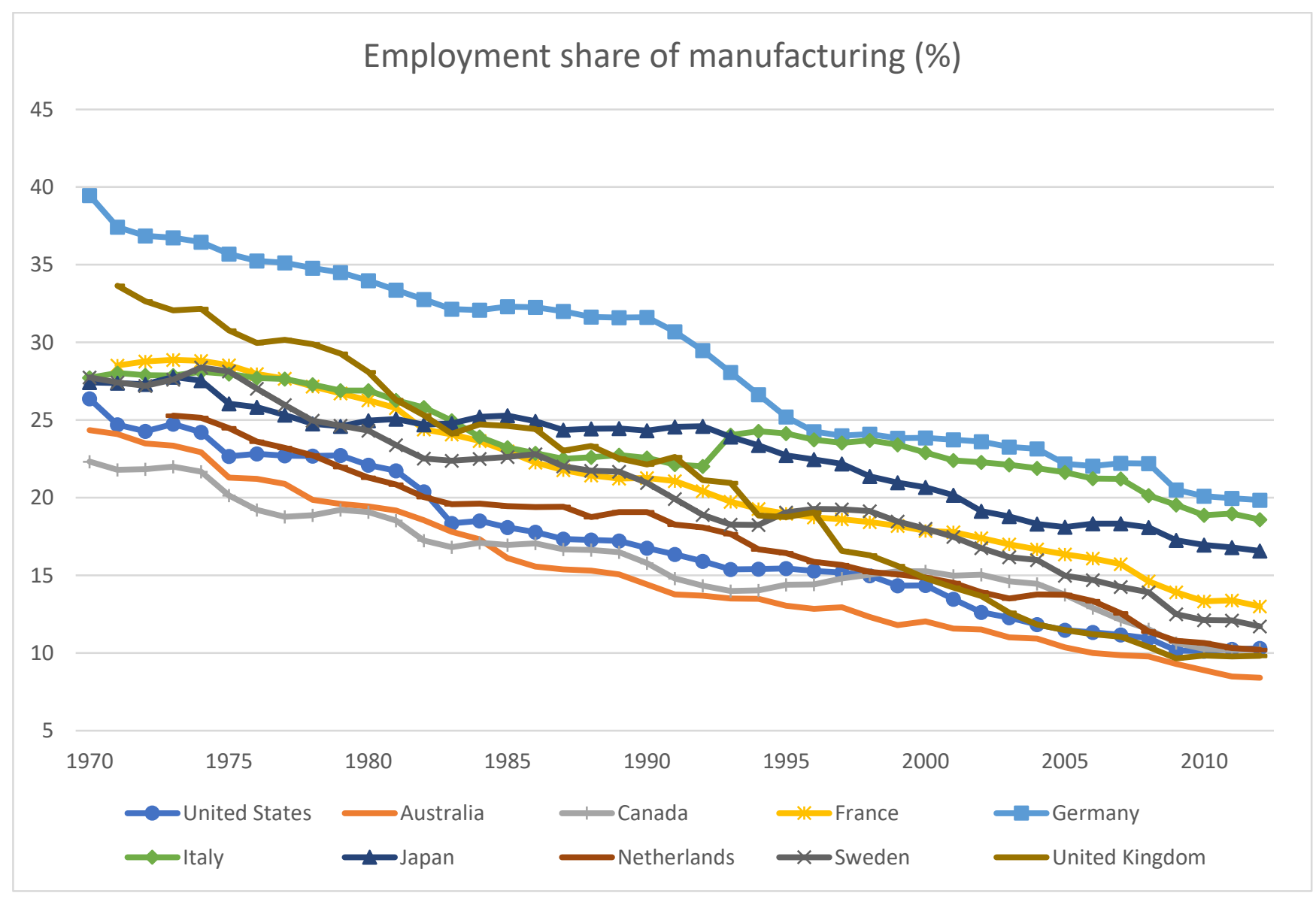

Figure 4.2 Manufacturing employment share (\%), 1970-2012

Source: Division of International Labour Comparisons, U.S Bureau of Labour Statistic, and International Labour Organizations 
Table 4.4 Baseline results - Manufacturing value share and manufacturing employment share

\begin{tabular}{|c|c|c|}
\hline \multirow{2}{*}{ Independent variables } & \multicolumn{2}{|c|}{$\begin{array}{c}\text { Dependent variable } \\
\text { Income shares of top } 10 \%\end{array}$} \\
\hline & Model 1 & Model 2 \\
\hline \multirow{2}{*}{ Manufacturing/GDP } & .95402 & 1.11973 \\
\hline & $(.14849)^{* * *}$ & $(.10318) * * *$ \\
\hline \multirow{2}{*}{ Manufacturing employment share } & -.26921 & -.42486 \\
\hline & $(.21648)$ & $(.10230) * * *$ \\
\hline \multirow{2}{*}{ Vocational share } & .11228 & .35033 \\
\hline & $(.05238)^{* *}$ & $(.09125) * * *$ \\
\hline \multirow{2}{*}{ Manufacturing/GDP x Vocational share } & -.01766 & -.06183 \\
\hline & $(.00371)^{* * *}$ & $(.00871)^{* * *}$ \\
\hline \multirow{2}{*}{ Manufacturing employment share x Vocational share } & .00911 & .03605 \\
\hline & $(.00328) * * *$ & $(.00735) * * *$ \\
\hline R-squared & .355 & .586 \\
\hline Time fixed effects & $\mathrm{x}$ & $\mathrm{x}$ \\
\hline Country fixed effects & $\mathrm{x}$ & $\mathrm{x}$ \\
\hline Number of countries & 23 & 20 \\
\hline Number of years & 16 & 24 \\
\hline Number of observations & 249 & 270 \\
\hline F-statistic & 173.940 & 161.133 \\
\hline Vocational measure & Vocational share in upper secondary & Ratio of youth enrolment in vocational \\
\hline
\end{tabular}




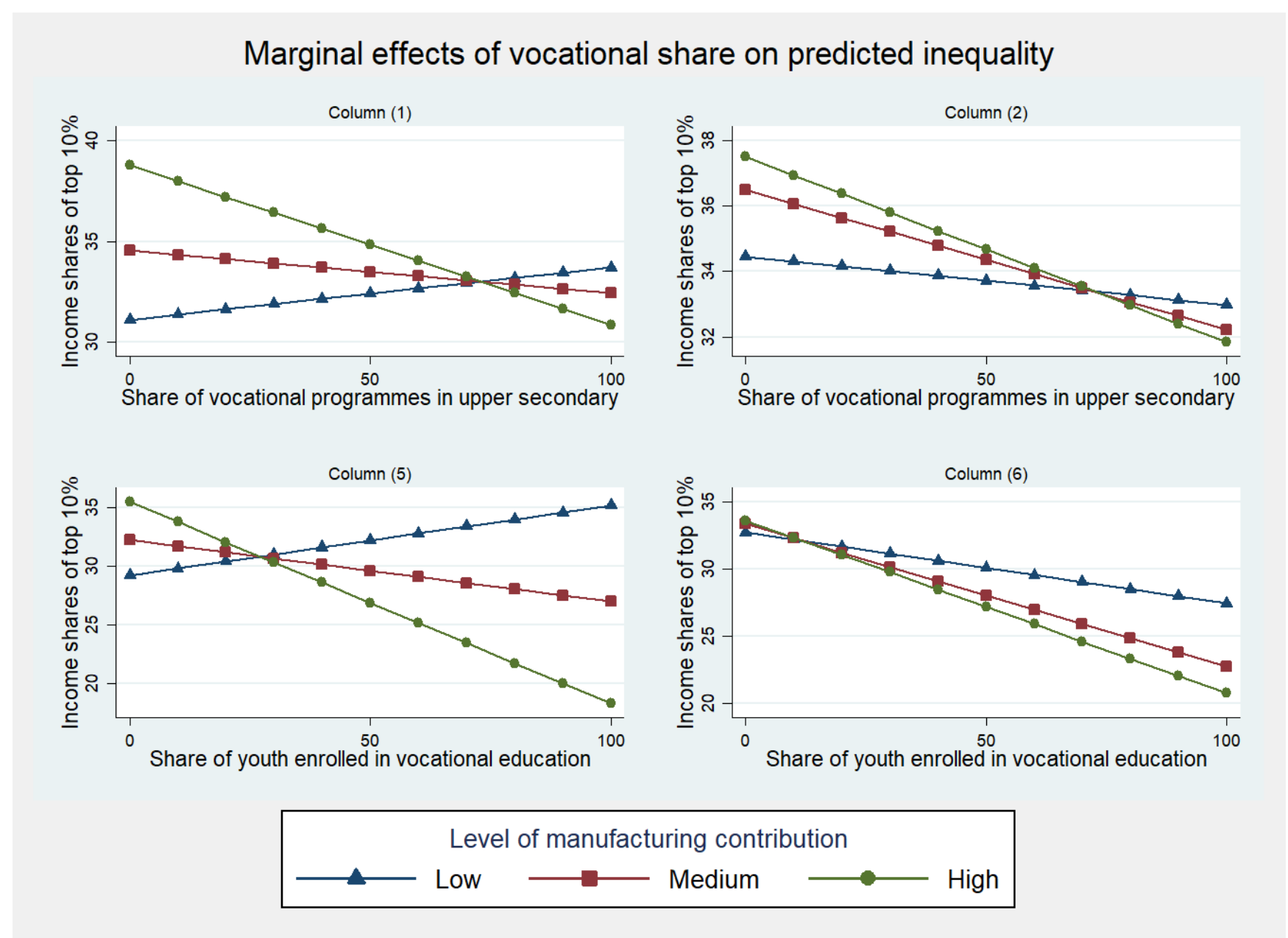

Note: The marginal effects of vocational share on predicted inequality are constructed by holding manufacturing variable constant at the $25^{\text {th }}-50^{\text {th }}-75^{\text {th }}$ percentile, which correspond to Low - Medium - High level of manufacturing's contribution to the economy. Manufacturing contribution is measured by manufacturing share in GDP (\% value-added) or manufacturing share in total merchandise export. Each graph corresponds to one specification in Table 4.3.

Figure 4.3 Marginal effects of vocational share on predicted inequality 
Table 4.5 Baseline results - Continuing vocational training measures

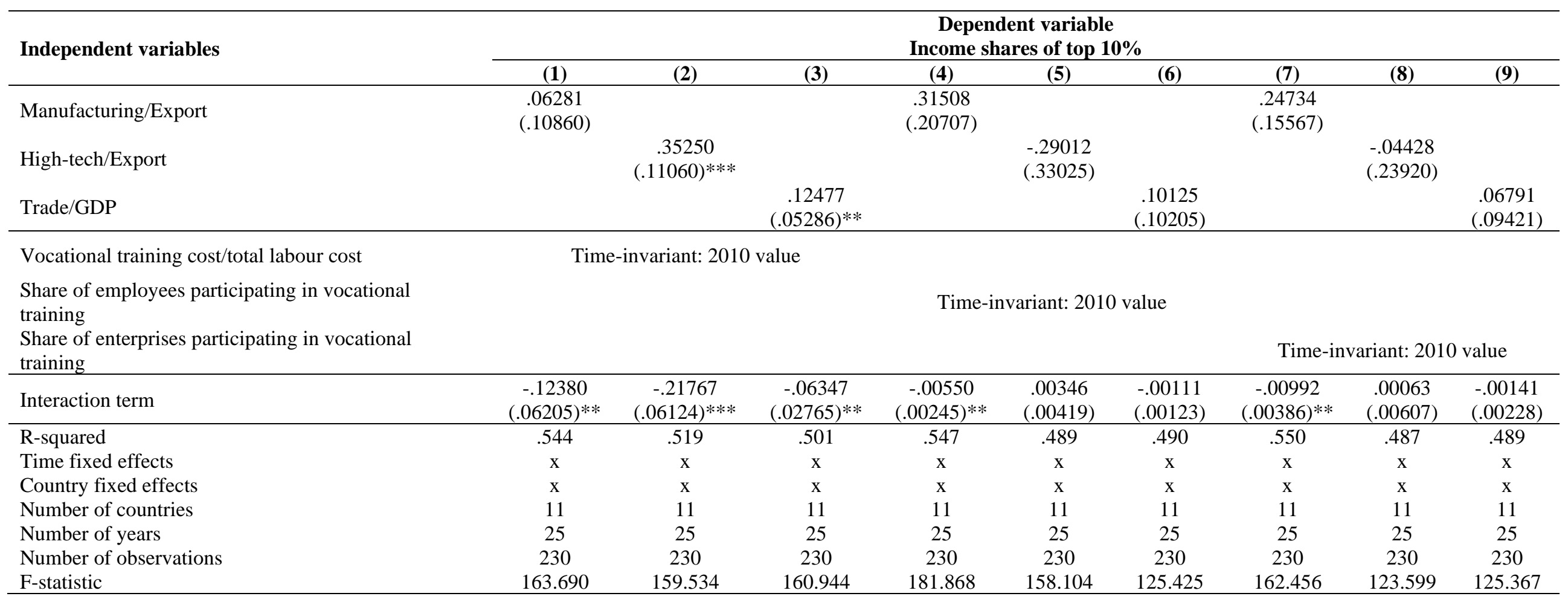

Note: Two-way fixed-effects estimations. $* * *, * * *$ denotes statistically significance at $1,5,10$ percent. Years covered but with some missing observations: $1990-2016 . *$ S80S20:

S80/S20 income quintile share ratio - Gini: Gini coefficient $(\%)$ 
Table 4.6 Baseline results - Alternative inequality measures

\begin{tabular}{|c|c|c|c|c|c|c|c|c|c|c|}
\hline \multirow{3}{*}{ Independent variables } & \multicolumn{10}{|c|}{ Dependent variable } \\
\hline & \multicolumn{5}{|c|}{ S80S20 } & \multicolumn{5}{|c|}{ Gini coefficient } \\
\hline & (1) & $(2)$ & (3) & (4) & (5) & (6) & (7) & (8) & (9) & (10) \\
\hline Manufacturing/GDP & $\begin{array}{c}-.30870 \\
(.08078)^{* * *}\end{array}$ & & & & & $\begin{array}{l}-.12946 \\
(.19650)\end{array}$ & & & & \\
\hline Manufacturing/Export & & $\begin{array}{c}.02748 \\
(.03462)\end{array}$ & & $\begin{array}{l}-0.00595 \\
(.03367)\end{array}$ & $\begin{array}{c}.10999 \\
(.06111)^{*}\end{array}$ & & $\begin{array}{c}.07425 \\
(.07655)\end{array}$ & & $\begin{array}{l}.11104 \\
(.11465)\end{array}$ & $\begin{array}{l}.34253 \\
.34253\end{array}$ \\
\hline High-tech exports/GDP & & & $\begin{array}{c}-.10713 \\
(.04357)^{* *}\end{array}$ & & & & & $\begin{array}{l}-.08716 \\
(.10148)\end{array}$ & & \\
\hline Vocational share in upper secondary & $\begin{array}{c}-.06307 \\
(.02569) * *\end{array}$ & $\begin{array}{c}.00015 \\
(.03274)\end{array}$ & $\begin{array}{c}-.03782 \\
(.01730)^{* *}\end{array}$ & & & $\begin{array}{l}-.00427 \\
(.06248)\end{array}$ & $\begin{array}{c}.16913 \\
(.07241)^{* *}\end{array}$ & $\begin{array}{l}-.03331 \\
(.04028)\end{array}$ & & \\
\hline Ratio of youth enrolment in vocational & & & & $\begin{array}{c}.15194 \\
(.10064)\end{array}$ & & & & & $\begin{array}{c}.89241 \\
(.34266)^{* *}\end{array}$ & \\
\hline Vocational training cost/ Labour cost & & & & & $\begin{array}{c}\text { Time- } \\
\text { invariant: } \\
2010 \text { value }\end{array}$ & & & $\begin{array}{l}\text { Time- } \\
\text { invariant: } \\
2010 \text { value }\end{array}$ & & $\begin{array}{c}\text { Time- } \\
\text { invariant: } \\
2010 \text { value }\end{array}$ \\
\hline Interaction term & $\begin{array}{c}.00424 \\
(.00172)^{* *}\end{array}$ & $\begin{array}{l}-.00013 \\
(.00054)\end{array}$ & $\begin{array}{c}.00243 \\
(.00094) * *\end{array}$ & $\begin{array}{c}-.00146 \\
(.00146)\end{array}$ & $\begin{array}{c}-.08991 \\
(.03797) * *\end{array}$ & $\begin{array}{c}.00023 \\
(.00419) \\
\end{array}$ & $\begin{array}{c}-.00290 \\
(.00118) * *\end{array}$ & $\begin{array}{c}.00261 \\
(.00219) \\
\end{array}$ & $\begin{array}{c}-.01156 \\
(.00499) * *\end{array}$ & $\begin{array}{c}-.29719 \\
(.13079)^{* *}\end{array}$ \\
\hline R-squared & .478 & .421 & .450 & .380 & .105 & .200 & .308 & .271 & .292 & .126 \\
\hline Time fixed effects & $\mathrm{x}$ & $\mathrm{x}$ & $\mathrm{X}$ & & $\mathrm{x}$ & $\mathrm{X}$ & $\mathrm{x}$ & $\mathrm{X}$ & $\mathrm{x}$ & $\mathrm{x}$ \\
\hline Country fixed effects & $\mathrm{x}$ & $\mathrm{x}$ & $\mathrm{x}$ & & $\mathrm{x}$ & $\mathrm{x}$ & $\mathrm{x}$ & $\mathrm{x}$ & $\mathrm{x}$ & $\mathrm{x}$ \\
\hline Number of countries & 21 & 21 & 21 & 17 & 11 & 21 & 21 & 21 & 17 & 11 \\
\hline Number of years & 12 & 12 & 12 & 9 & 9 & 12 & 12 & 12 & 9 & 9 \\
\hline Number of observations & 146 & 148 & 148 & 111 & 95 & 146 & 148 & 148 & 111 & 95 \\
\hline F-statistic & 226.736 & 152.660 & 192.772 & 73.545 & 53.496 & 115.858 & 89.419 & 110.401 & 45.625 & 53.712 \\
\hline
\end{tabular}

Note: Two-way fixed-effects estimations. ***,**,* denotes statistically significance at $1,5,10$ percent. Years covered but with some missing observations: $1990-2016 . *$ S80S20: S80/S20 income quintile share ratio - Gini: Gini coefficient (\%) 
Table 4.7 Alternative inequality measures - Extended sample

\begin{tabular}{|c|c|c|c|c|c|c|c|c|c|c|}
\hline \multirow{3}{*}{ Independent variables } & \multicolumn{10}{|c|}{ Dependent variable } \\
\hline & \multicolumn{5}{|c|}{ S80S20 } & \multicolumn{5}{|c|}{ Gini coefficient } \\
\hline & (1) & $(2)$ & (3) & (4) & (5) & (6) & (7) & (8) & $(9)$ & (10) \\
\hline Manufacturing/GDP & $\begin{array}{c}.32605 \\
(.09415)^{* * *}\end{array}$ & & & $\begin{array}{c}.21339 \\
(.07814)^{* * *}\end{array}$ & & $\begin{array}{l}.14754 \\
(.09981)\end{array}$ & & & $\begin{array}{l}.13307 \\
(.09211)\end{array}$ & \\
\hline Manufacturing/Export & & $\begin{array}{c}.07741 \\
(.02453)^{* * *}\end{array}$ & & & & & $\begin{array}{c}.04497 \\
(.02567)^{*}\end{array}$ & & & $\begin{array}{c}.01283 \\
(.02137)\end{array}$ \\
\hline High-tech exports/GDP & & & $\begin{array}{c}-.00435 \\
(.03450) \\
\end{array}$ & & $\begin{array}{c}.07814 \\
(.03871)^{* *} \\
\end{array}$ & & & $\begin{array}{c}.20535 \\
(.12013)^{*} \\
\end{array}$ & & \\
\hline Vocational share in upper secondary & $\begin{array}{c}-.35743 \\
(1.90576)\end{array}$ & $\begin{array}{c}.21229 \\
(.03470)^{* * *}\end{array}$ & $\begin{array}{c}.06075 \\
(.02194)^{* * *}\end{array}$ & & & $\begin{array}{c}.06365 \\
(.04063)\end{array}$ & $\begin{array}{c}.12377 \\
(.03632)^{* * *}\end{array}$ & & & \\
\hline Ratio of youth enrolment in vocational & & & & $\begin{array}{c}.19574 \\
(.10751)^{*}\end{array}$ & & & & & $\begin{array}{c}.06889 \\
(.12674)\end{array}$ & $\begin{array}{c}.08031 \\
(.13941)\end{array}$ \\
\hline Vocational training cost/ Labour cost & & & & & $\begin{array}{c}\text { Time- } \\
\text { invariant: } \\
2010 \text { value }\end{array}$ & & & $\begin{array}{c}\text { Time- } \\
\text { invariant: } \\
2010 \text { value }\end{array}$ & & \\
\hline Interaction term & $\begin{array}{c}-.00422 \\
(.00193) * *\end{array}$ & $\begin{array}{c}-.00291 \\
(.00052)^{* * *}\end{array}$ & $\begin{array}{c}-.00070 \\
(.00100) \\
\end{array}$ & $\begin{array}{c}-.00904 \\
(.00554)^{*} \\
\end{array}$ & $\begin{array}{c}.03018 \\
(.02324) \\
\end{array}$ & $\begin{array}{c}-.00193 \\
(.00205) \\
\end{array}$ & $\begin{array}{c}-.00169 \\
(.00055)^{* * *} *\end{array}$ & $\begin{array}{l}.07198 \\
(.07212) \\
\end{array}$ & $\begin{array}{l}-.00036 \\
(.00654) \\
\end{array}$ & $\begin{array}{l}-.00032 \\
(.00193) \\
\end{array}$ \\
\hline R-squared & .109 & .159 & .096 & .178 & .300 & .098 & .130 & .243 & .158 & .153 \\
\hline Time fixed effects & $\mathrm{x}$ & $\mathrm{x}$ & $\mathrm{X}$ & $\mathrm{x}$ & $\mathrm{x}$ & $\mathrm{x}$ & $\mathrm{x}$ & $\mathrm{x}$ & $\mathrm{x}$ & $\mathrm{x}$ \\
\hline Country fixed effects & $\mathrm{X}$ & $\mathrm{x}$ & $\mathrm{x}$ & $\mathrm{X}$ & $\mathrm{X}$ & $\mathrm{X}$ & $\mathrm{x}$ & $\mathrm{x}$ & $\mathrm{x}$ & $\mathrm{x}$ \\
\hline Number of countries & 65 & 65 & 65 & 54 & 27 & 65 & 65 & 27 & 54 & 54 \\
\hline Number of years & 16 & 16 & 16 & 17 & 19 & 16 & 16 & 19 & 17 & 17 \\
\hline Number of observations & 517 & 512 & 512 & 404 & 293 & 517 & 512 & 293 & 404 & 406 \\
\hline F-statistic & 57.324 & 46.824 & 52.091 & 51.159 & 25.318 & 131.695 & 114.504 & 32.569 & 104.032 & 86.605 \\
\hline
\end{tabular}

Note: Two-way fixed-effects estimations. ***,**,* denotes statistically significance at $1,5,10$ percent. Years covered but with some missing observations: $1990-2016 . *$ S80S20:

S80/S20 income quintile share ratio - Gini: Gini coefficient (\%) 


\section{Manufacturing (\% value added in GDP)}

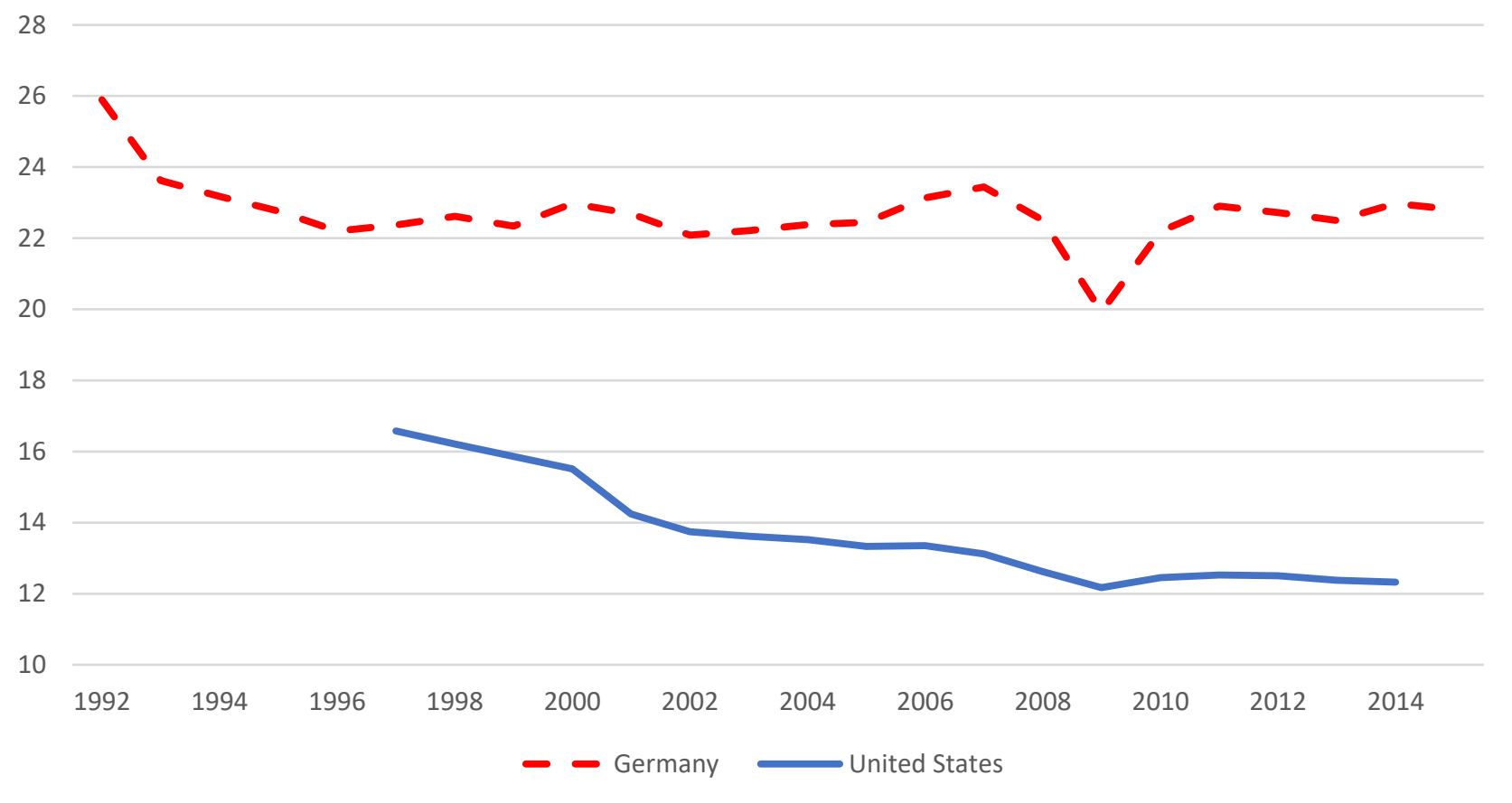

Figure 4.4 Manufacturing (\% of value-added in GDP)

Source: OECD 


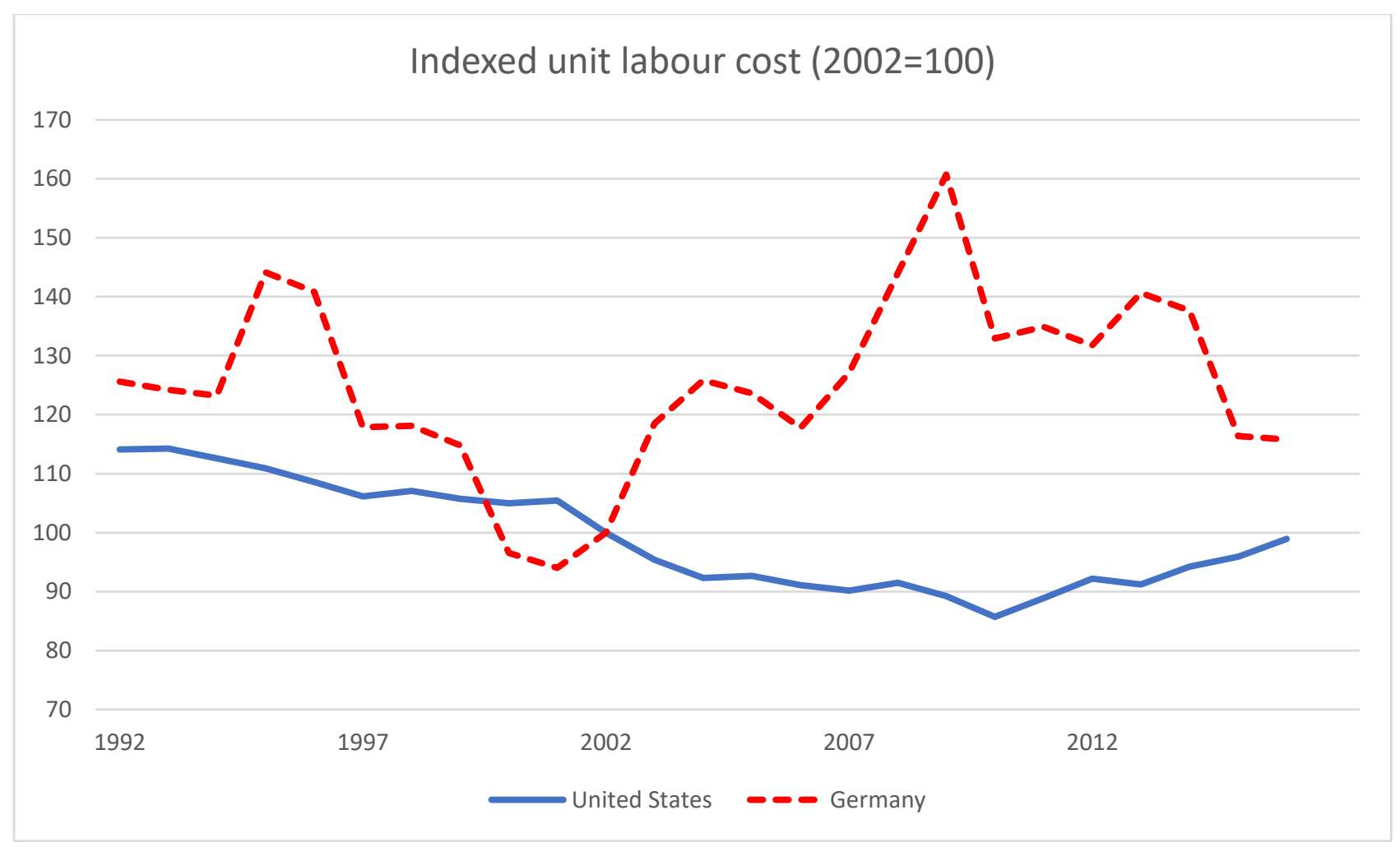

Figure 4.5 Indexed Unit Labour Costs in the Manufacturing Sector, 1992-2016 Source: The Conference Board, International Labour Comparisons Program, May 2017 
Table 4.8 Education: Germany versus the USA (\% of the population - average 2011-2015)

\begin{tabular}{lccc}
\hline & USA & Germany & Difference \\
\hline Below upper secondary & 10.5 & 13.2 & -2.7 \\
Upper secondary & 44.9 & 59.2 & -14.3 \\
Tertiary & 44.6 & 27.6 & 17 \\
S80/S20 & 18.6 & 11.0 & \\
Gini & 0.45 & 0.27 & \\
Manufacturing/GDP & 12 & 22 & \\
\hline
\end{tabular}

Source: World Development Indicator and Poverty and Equity Database, World Bank 


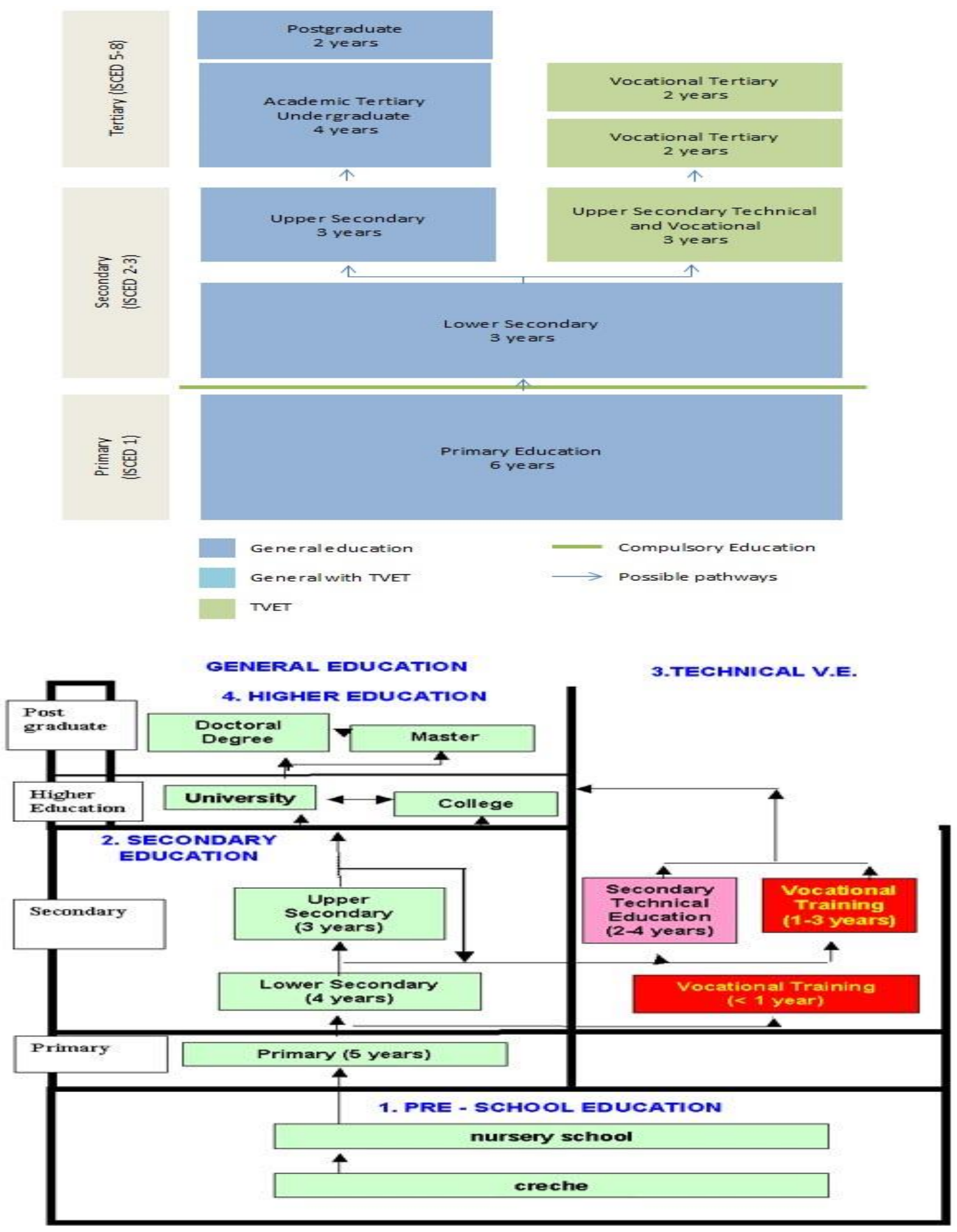

Figure 4.6 Structure of Educational System in Thailand (upper) and Vietnam (lower)

Source: Implementing UNESCO / ILO Recommendations for Technical and Vocational Education and Training, Japan National Institute for Educational Policy Research (2002) 

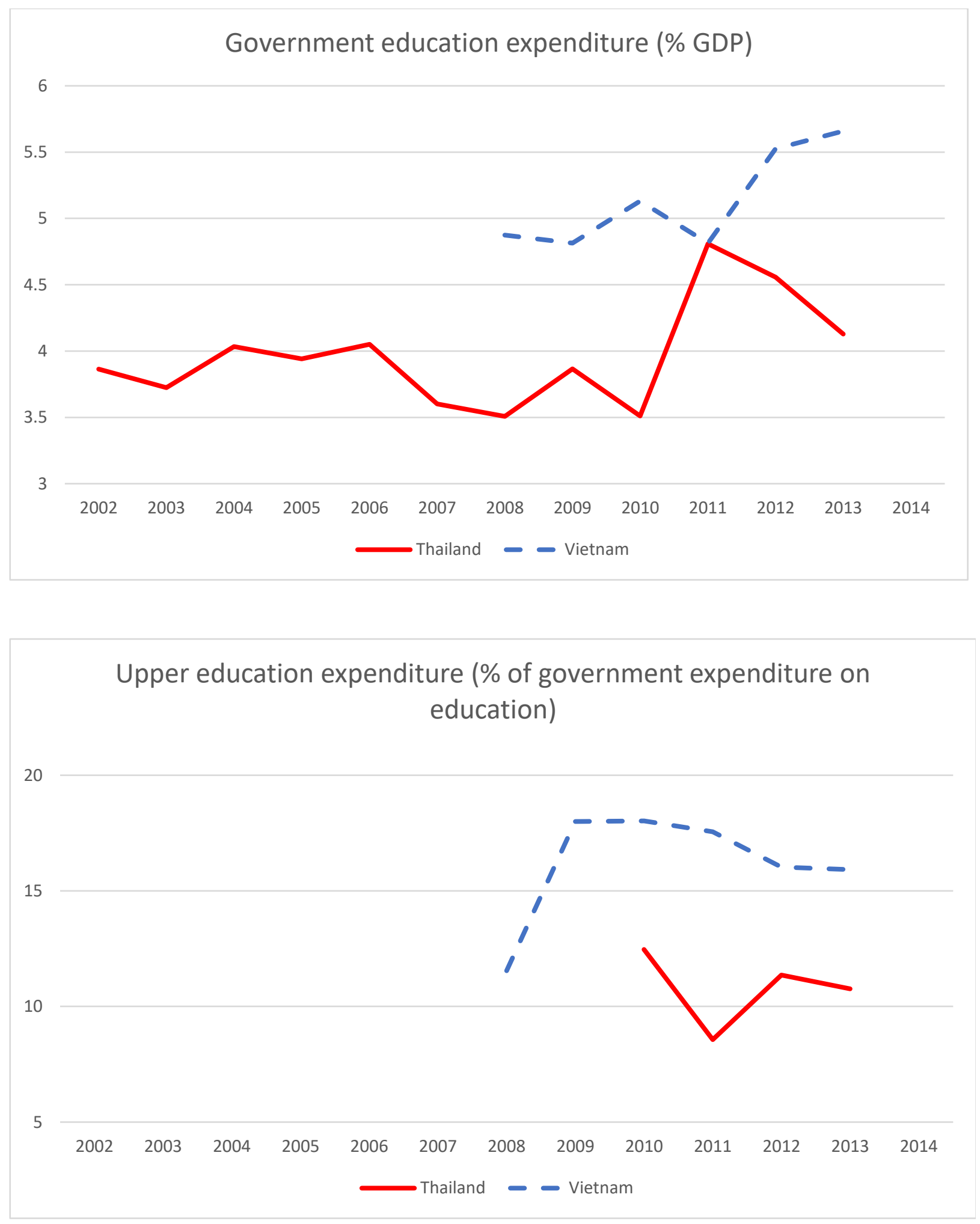

Figure 4.7 Education Budget

Source: UNESCO Institute for Statistics 


\begin{tabular}{|c|c|c|c|c|c|}
\hline \multirow[b]{2}{*}{ Country } & \multicolumn{4}{|c|}{ Ranking } & \\
\hline & 2010 & 2013 & 2016 & 2020 (projected) & \\
\hline China & 1 & 1 & 1 & 2 & \\
\hline United States & 4 & 3 & 2 & 1 & \\
\hline Germany & 8 & 2 & 3 & 3 & \\
\hline Japan & 6 & 10 & 4 & 4 & \\
\hline South Korea & 3 & 5 & 5 & 6 & \\
\hline United Kingdom & 17 & 15 & 6 & 8 & \\
\hline Taiwan & & 6 & 7 & 9 & \\
\hline Mexico & 7 & 12 & 8 & 7 & \\
\hline Canada & 13 & 7 & 9 & 10 & \\
\hline Singapore & 9 & 9 & 10 & 11 & \\
\hline India & 2 & 4 & 11 & 5 & \\
\hline Switzerland & 14 & 22 & 12 & 19 & \\
\hline Sweden & & 21 & 13 & 18 & \\
\hline Thailand & 12 & 11 & 14 & 14 & \\
\hline Poland & 10 & 14 & 15 & 16 & \\
\hline Turkey & & 20 & 16 & 17 & \\
\hline Malaysia & & 13 & 17 & 13 & \\
\hline Vietnam & & 18 & 18 & 12 & \\
\hline Indonesia & & 17 & 19 & 15 & \\
\hline Netherlands & 16 & 23 & 20 & 21 & \\
\hline Australia & 15 & 16 & 21 & 22 & 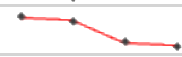 \\
\hline France & 23 & 25 & 22 & 26 & \\
\hline Czech Republic & 11 & 19 & 23 & 20 & 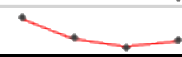 \\
\hline
\end{tabular}

* 2020 index is projected only

\begin{tabular}{|c|c|c|c|c|c|}
\hline & & Thailand & Vietnam & Germany & $\underline{\mathrm{USA}}$ \\
\hline Manufacturing & bil.\$ & 71.9 & 21.3 & 663 & 1,820 \\
\hline \multirow[t]{2}{*}{ Size (2013) } & $\%$ GDP & 25.7 & 17.5 & 22.2 & 12.3 \\
\hline & 3-Year Growth (\%) & 0.7 & 8.1 & 2.8 & 0.8 \\
\hline Manufacturing Labour Cost (2015) & per hour $(\$)$ & 2.78 & 1.96 & 40.54 & 37.96 \\
\hline Productivity (2014) & GDP/person $(\$)$ & $23,862.70$ & $8,935.90$ & $87,208.3$ & $110,049.5$ \\
\hline Manufacturing Exports & bil. $\$$ & 167.1 & 107.9 & $1,248.6$ & $1,034.2$ \\
\hline
\end{tabular}

Figure 4.8 Manufacturing Competitiveness

Source: Deloitte (2010,2013,2016) Global Manufacturing Competitiveness Report 

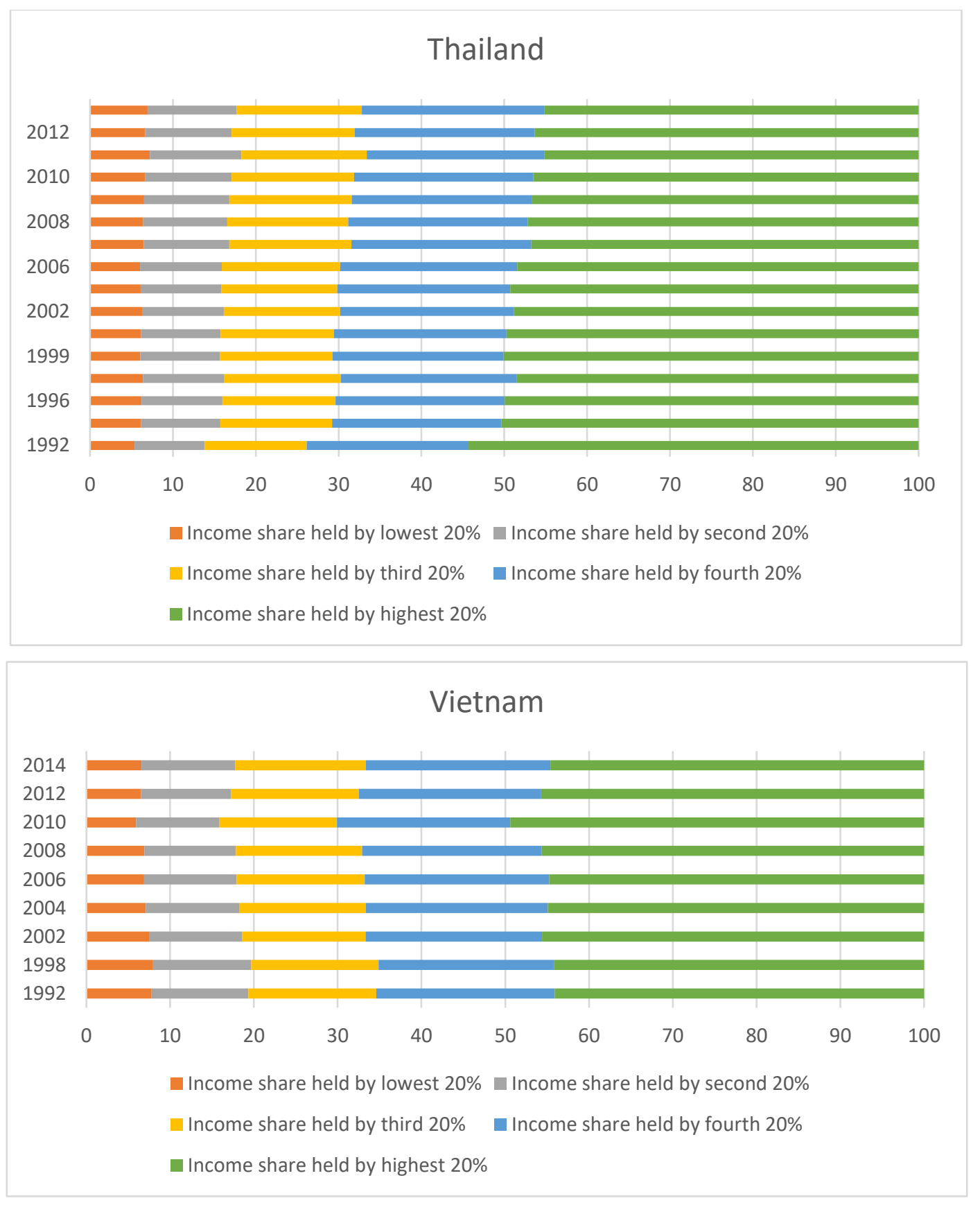

Figure 4.9 Distribution of Income of Thailand (upper) and Vietnam (lower)

Source: Poverty and Equity Database, World Bank 


\section{Appendix}

Table A: Country list

\begin{tabular}{|c|c|c|c|c|}
\hline \multirow[t]{2}{*}{ Name } & \multirow[t]{2}{*}{ ISO code } & \multirow[t]{2}{*}{ Income group } & \multicolumn{2}{|c|}{ Sample } \\
\hline & & & Baseline & Extended \\
\hline Albania & ALB & Upper-middle & & $\mathrm{x}$ \\
\hline Argentina & ARG & Upper-middle & & $\mathrm{x}$ \\
\hline Australia & AUS & High & $\mathrm{x}$ & $\mathrm{x}$ \\
\hline Austria & AUT & High & & $\mathrm{x}$ \\
\hline Azerbaijan & AZE & Upper-middle & & $\mathrm{x}$ \\
\hline Belgium & BEL & High & & $\mathrm{x}$ \\
\hline Bulgaria & BGR & Upper-middle & & $\mathrm{x}$ \\
\hline Bosnia and Herzegovina & $\mathrm{BIH}$ & Upper-middle & & $\mathrm{x}$ \\
\hline Belarus & BLR & Upper-middle & & $\mathrm{x}$ \\
\hline Brazil & BRA & Upper-middle & & $\mathrm{x}$ \\
\hline Botswana & BWA & Upper-middle & & $\mathrm{x}$ \\
\hline Canada & CAN & High & & $\mathrm{x}$ \\
\hline Switzerland & CHE & High & $\mathrm{x}$ & $\mathrm{x}$ \\
\hline Chile & $\mathrm{CHL}$ & High & & $\mathrm{x}$ \\
\hline China & $\mathrm{CHN}$ & Upper-middle & $\mathrm{x}$ & $\mathrm{x}$ \\
\hline Colombia & $\mathrm{COL}$ & Upper-middle & & $\mathrm{x}$ \\
\hline Costa Rica & CRI & Upper-middle & & $\mathrm{x}$ \\
\hline Cyprus & CYP & High & & $\mathrm{x}$ \\
\hline Czech Republic & $\mathrm{CZE}$ & High & & $\mathrm{x}$ \\
\hline Germany & DEU & High & $\mathrm{x}$ & $\mathrm{x}$ \\
\hline Denmark & DNK & High & $\mathrm{x}$ & $\mathrm{x}$ \\
\hline Dominican Republic & DOM & Upper-middle & & $\mathrm{x}$ \\
\hline Ecuador & ECU & Upper-middle & & $\mathrm{x}$ \\
\hline Spain & ESP & High & $\mathrm{x}$ & $\mathrm{x}$ \\
\hline Estonia & EST & High & & $\mathrm{x}$ \\
\hline Finland & FIN & High & $\mathrm{x}$ & $\mathrm{x}$ \\
\hline Fiji & FJI & Upper-middle & & $\mathrm{x}$ \\
\hline France & FRA & High & $\mathrm{x}$ & $\mathrm{x}$ \\
\hline United Kingdom & GBR & High & $\mathrm{x}$ & $\mathrm{x}$ \\
\hline Georgia & GEO & Upper-middle & & $\mathrm{x}$ \\
\hline Greece & GRC & High & & $\mathrm{x}$ \\
\hline Croatia & HRV & High & & $\mathrm{x}$ \\
\hline
\end{tabular}




\begin{tabular}{|c|c|c|c|c|}
\hline Hungary & HUN & High & & $\mathrm{x}$ \\
\hline Ireland & IRL & High & & $\mathrm{x}$ \\
\hline Iran & IRN & Upper-middle & & $\mathrm{x}$ \\
\hline Iceland & ISL & High & & $\mathrm{x}$ \\
\hline Israel & ISR & High & $\mathrm{x}$ & $\mathrm{x}$ \\
\hline Italy & ITA & High & $\mathrm{x}$ & $\mathrm{x}$ \\
\hline Jamaica & JAM & Upper-middle & & $\mathrm{x}$ \\
\hline Japan & JPN & High & $\mathrm{x}$ & $\mathrm{x}$ \\
\hline Kazakhstan & KAZ & Upper-middle & & $\mathrm{x}$ \\
\hline Korea & KOR & High & $\mathrm{x}$ & $\mathrm{x}$ \\
\hline Lithuania & LTU & High & & $\mathrm{x}$ \\
\hline Luxembourg & LUX & High & & $\mathrm{x}$ \\
\hline Latvia & LVA & High & & $\mathrm{x}$ \\
\hline Mexico & MEX & Upper-middle & & $\mathrm{x}$ \\
\hline Macedonia & MKD & Upper-middle & & $\mathrm{x}$ \\
\hline Montenegro & MNE & Upper-middle & & $\mathrm{x}$ \\
\hline Mauritius & MUS & Upper-middle & $\mathrm{x}$ & $\mathrm{x}$ \\
\hline Malaysia & MYS & Upper-middle & $\mathrm{x}$ & $\mathrm{x}$ \\
\hline Netherlands & NLD & High & $\mathrm{x}$ & $\mathrm{x}$ \\
\hline Norway & NOR & High & $\mathrm{x}$ & $\mathrm{x}$ \\
\hline New Zealand & NZL & High & $\mathrm{x}$ & $\mathrm{x}$ \\
\hline Panama & PAN & Upper-middle & & $\mathrm{x}$ \\
\hline Poland & POL & High & & $\mathrm{x}$ \\
\hline Portugal & PRT & High & $\mathrm{x}$ & $\mathrm{x}$ \\
\hline Paraguay & PRY & Upper-middle & & $\mathrm{x}$ \\
\hline Romania & ROU & Upper-middle & & $\mathrm{x}$ \\
\hline Russian Federation & RUS & Upper-middle & $\mathrm{x}$ & $\mathrm{x}$ \\
\hline Singapore & SGP & High & $\mathrm{x}$ & $\mathrm{x}$ \\
\hline Serbia & SRB & Upper-middle & & $\mathrm{x}$ \\
\hline Slovakia & SVK & High & & $\mathrm{x}$ \\
\hline Slovenia & SVN & High & & $\mathrm{x}$ \\
\hline Sweden & SWE & High & $\mathrm{x}$ & $\mathrm{x}$ \\
\hline Seychelles & SYC & High & & $\mathrm{x}$ \\
\hline Thailand & THA & Upper-middle & & $\mathrm{x}$ \\
\hline Turkey & TUR & Upper-middle & & $\mathrm{x}$ \\
\hline Uruguay & URY & High & $\mathrm{x}$ & $\mathrm{x}$ \\
\hline Venezuela & VEN & Upper-middle & & $\mathrm{x}$ \\
\hline
\end{tabular}


South Africa

ZAF

Upper-middle

X

X 
Table B: Summary statistics - extended sample

\begin{tabular}{lccc}
\hline Variables & count & mean & sd \\
\hline Income share of top 10\% & 486 & 33.583 & 6.895 \\
Income quintile share ratio S80S20 & 730 & 9.070 & 6.467 \\
GINI index (World Bank estimate) & 730 & 38.475 & 9.898 \\
P90/P10 inequality index(OECD) & 293 & 4.561 & 4.637 \\
Manufacturing, value added (\% of GDP) & 1664 & 17.350 & 6.320 \\
Manufactures exports (\% of merchandise exports) & 1680 & 58.273 & 27.210 \\
High-technology exports (\% of manufactured exports) & 1625 & 12.816 & 15.426 \\
Trade (\% of GDP) & 1824 & 89.142 & 56.227 \\
manufacturing employment share - ILO & 1551 & 16.362 & 5.630 \\
Share of vocational programmes in upper secondary education & 909 & 40.460 & 21.308 \\
Share of youth (15-24y) enrolled in secondary vocational education & 872 & 11.499 & 7.663 \\
Training enterprises as \% of all enterprises & 729 & 64.481 & 20.230 \\
Percentage of employees participating in CVT courses & 729 & 36.000 & 11.574 \\
Cost of CVT courses as \% of total labour cost (all enterprises) & 729 & 1.515 & 0.477 \\
\hline
\end{tabular}




\section{References}

Abreu, M., De Groot, H. L., \& Florax, R. J. (2005). A Meta-Analysis of $\beta$-Convergence: the Legendary 2\%. Journal of Economic Surveys, 19(3), 389-420.

Acemoglu, D., \& Restrepo, P. (2020). Robots and jobs: Evidence from US labor markets. Journal of Political Economy, 128(6), 2188-2244.

Aguiar, M., \& Bils, M. (2015). Has consumption inequality mirrored income inequality? American Economic Review, 105(9), 2725-2756.

Aitken, B., Harrison, A., \& Lipsey, R. E. (1996). Wages and foreign ownership A comparative study of Mexico, Venezuela, and the United States. Journal of International Economics, 40(3-4), 345-371.

Aizenman, J., Jinjarak, Y., Ngo, N., \& Noy, I. (2018). Vocational education, manufacturing, and income distribution: international evidence and case studies. Open Economies Review, 29(3), 641-664.

Aizenman, J., \& Noy, I. (2012). Reflections on the curious contrast of public policies between Germany and the US: Real estate versus human capital. voxEU. org, 25.

Anselin, L. (2013). Spatial econometrics: methods and models (Vol. 4): Springer Science \& Business Media.

Anselin, L., \& Rey, S. (1991). Properties of tests for spatial dependence in linear regression models. Geographical Analysis, 23(2), 112-131.

Arbia, G. (2006). Spatial econometrics: statistical foundations and applications to regional convergence: Springer Science \& Business Media.

Arellano, M., \& Bond, S. (1991). Some tests of specification for panel data: Monte Carlo evidence and an application to employment equations. The Review of Economic Studies, 58(2), 277297.

Aroca, P., Guo, D., \& Hewings, G. J. (2006). Spatial convergence in China: 1952-99: Research Paper, UNU-WIDER, United Nations University (UNU).

Attanasio, O., Guarín, A., Medina, C., \& Meghir, C. (2017). Vocational training for disadvantaged youth in colombia: A long-term follow-up. American Economic Journal: Applied Economics, 9(2), 131-143.

Attanasio, O., Hurst, E., \& Pistaferri, L. (2012). The evolution of income, consumption, and leisure inequality in the US, 1980-2010 (0898-2937). Retrieved from 
Attanasio, O., Kugler, A., \& Meghir, C. (2011). Subsidizing vocational training for disadvantaged youth in Colombia: Evidence from a randomized trial. American Economic Journal: Applied Economics, 3(3), 188-220.

Autor, D. H., Dorn, D., Hanson, G. H., \& Song, J. (2014). Trade adjustment: Worker-level evidence. The Quarterly Journal of Economics, 129(4), 1799-1860.

Badinger, H., Müller, W., \& Tondl, G. (2004). Regional convergence in the European Union, 1985-1999: A spatial dynamic panel analysis. Regional Studies, 38(3), 241-253.

Bahar, D., Hausmann, R., \& Hidalgo, C. A. (2014). Neighbors and the evolution of the comparative advantage of nations: Evidence of international knowledge diffusion? Journal of International Economics, 92(1), 111-123.

Bank, A. D. (2014). Technical and vocational education and training in the Socialist Republic of Viet Nam: an assessment.

Barro, R. J. (2016). Economic growth and convergence, applied especially to China. Retrieved from

Barro, R. J., Sala-i-Martin, X., Blanchard, O. J., \& Hall, R. E. (1991). Convergence across states and regions. Brookings Papers on Economic Activity, 107-182.

Barry, F., Görg, H., \& Strobl, E. (2005). Foreign direct investment and wages in domestic firms in Ireland: Productivity spillovers versus labour-market crowding out. International Journal of the Economics of Business, 12(1), 67-84.

Bartik, T. J. (1991). Who benefits from state and local economic development policies?

Baumol, W. J. (1986). Productivity growth, convergence, and welfare: what the long-run data show. The American Economic Review, 1072-1085.

Behar, A. (2016). The endogenous skill bias of technical change and wage inequality in developing countries. The Journal of International Trade \& Economic Development, 25(8), 11011121.

Belotti, F., Hughes, G., \& Mortari, A. P. (2016). XSMLE: Stata module for spatial panel data models estimation. Statistical Software Components.

Ben-David, D. (1993). Equalizing exchange: Trade liberalization and income convergence. The Quarterly Journal of Economics, 108(3), 653-679.

Bertrand, M., Duflo, E., \& Mullainathan, S. (2004). How much should we trust differences-indifferences estimates? The Quarterly Journal of Economics, 119(1), 249-275. 
Blattman, C., Fiala, N., \& Martinez, S. (2014). Generating skilled self-employment in developing countries: Experimental evidence from Uganda. The Quarterly Journal of Economics, 129(2), 697-752.

Bosworth, B., \& Collins, S. M. (2008). Accounting for growth: comparing China and India. Journal of Economic Perspectives, 22(1), 45-66.

Bronzini, R. (2004). Foreign direct investment and agglomeration: evidence from Italy. Bank of Italy Working Paper No. 526

Bui, A. T., Nguyen, C. V., \& Pham, T. P. (2019). Impact of foreign investment on household welfare: Evidence from Vietnam. Journal of Asian Economics, 64, 101130.

Bussi, M., Hilal, S. E. A., Lanzona, L. A., \& Huang, Q. (2016). Compilation of assessment studies on technical vocational education and training (TVET): Lao People's Democratic Republic, Mongolia, the Philippines, Thailand and Viet Nam.

Card, D., Ibarrarán, P., Regalia, F., Rosas-Shady, D., \& Soares, Y. (2011). The labor market impacts of youth training in the Dominican Republic. Journal of Labor Economics, 29(2), 267-300.

Case, A., \& Deaton, A. (2015). Rising morbidity and mortality in midlife among white nonHispanic Americans in the 21st century. Proceedings of the National Academy of Sciences, 112(49), 15078-15083.

Case, A., \& Deaton, A. (2017). Mortality and morbidity in the 21st century. Brookings Papers on Economic Activity, 2017(1), 397-476.

Celbis, M. G., \& Crombrugghe, D. (2016). Internet infrastructure and regional convergence: Evidence from Turkey. Papers in Regional Science.

Chatterji, M., \& Dewhurst, J. L. (1996). Convergence clubs and relative economic performance in Great Britain: 1977-1991. Regional Studies, 30(1), 31-39.

Chen, D. (2009). Vocational Schooling, Labor Market Outcomes, and College Entry: Vocational Schooling, Labor Market Outcomes, and College Entry: The World Bank.

Chen, Z., Ge, Y., \& Lai, H. (2011). Foreign direct investment and wage inequality: Evidence from China. World Development, 39(8), 1322-1332.

Chintrakarn, P., Herzer, D., \& Nunnenkamp, P. (2012). FDI and income inequality: Evidence from a panel of US states. Economic inquiry, 50(3), 788-801. 
Chiquiar, D. (2008). Globalization, regional wage differentials and the Stolper-Samuelson Theorem: Evidence from Mexico. Journal of International Economics, 74(1), 70-93.

Crespo, N., Proença, I., \& Fontoura, M. P. (2012). The spatial dimension in FDI spillovers: Evidence at the regional level from Portugal. Regional and Sectoral Economic Studies, 12(1), 95-110.

CRFB. (2016). Committee for a Responsible Federal Budget: Analyzing Clinton's Health and Education Expansions. doi:http://www.crfb.org/blogs/analyzing-clintons-health-andeducation-expansions

Crozet, M., Mayer, T., \& Mucchielli, J.-L. (2004). How do firms agglomerate? A study of FDI in France. Regional Science and Urban Economics, 34(1), 27-54.

Deaton, A. (2008). Income, health, and well-being around the world: Evidence from the Gallup World Poll. Journal of Economic perspectives, 22(2), 53-72.

Deloitte. (2010). Global Manufacturing Competitiveness Index.

Deloitte. (2013). Global Manufacturing Competitiveness Index.

Deming, D. J., Goldin, C., \& Katz, L. F. (2012). The For-Profit Postsecondary School Sector: Nimble Critters or Agile Predators? Journal of Economic Perspectives, 26(1), 139-164. doi:10.1257/jep.26.1.139

Driffield, N. (2004). Regional policy and spillovers from FDI in the UK. The Annals of Regional Science, 38(4), 579-594.

Driffield, N., \& Girma, S. (2003). Regional foreign direct investment and wage spillovers: Plant level evidence from the UK electronics industry. Oxford Bulletin of Economics and Statistics, 65(4), 453-474.

Duranton, G., \& Puga, D. (2004). Micro-foundations of urban agglomeration economies. Handbook of regional and urban economics, 4, 2063-2117.

Economist, T. (2017). Special Report: Retraining low-skilled workers.

Edmonds, E. V., \& Pavcnik, N. (2005). The effect of trade liberalization on child labor. Journal of International Economics, 65(2), 401-419.

Education, G. F. M. o., \& Research. (2005). Reform of vocational education and training in Germany: the 2005 Vocational Training Act (Berufsbildungsgesetz 2005). 
El-Hamidi, F. (2006). General or vocational schooling? Evidence on school choice, returns, and'sheepskin'effects from Egypt 1998. Journal of Economic Policy Reform, 9(2), 157176.

Elhorst, J. P. (2010). Applied spatial econometrics: raising the bar. Spatial Economic Analysis, $5(1), 9-28$.

Elhorst, J. P. (2014). Spatial econometrics: from cross-sectional data to spatial panels: Springer.

Eurostat. (2014). Eurostat indicators of high-tech industry and knowledge-intensive services. In: European Commission Luxembourg.

Feenstra, R. C., \& Hanson, G. H. (1996). Globalization, outsourcing, and wage inequality (08982937). Retrieved from

Figini, P., \& Gorg, H. (2011). Does foreign direct investment affect wage inequality? An empirical investigation. The World Economy, 34(9), 1455-1475.

Fingleton, B., \& López-Bazo, E. (2006). Empirical growth models with spatial effects. Papers in Regional Science, 85(2), 177-198.

Fisher, J. D., Johnson, D. S., \& Smeeding, T. M. (2013). Measuring the trends in inequality of individuals and families: Income and consumption. American Economic Review, 103(3), 184-188.

Fleisher, B., Li, H., \& Zhao, M. Q. (2010). Human capital, economic growth, and regional inequality in China. Journal of Development Economics, 92(2), 215-231.

Forster, A. G., Bol, T., \& Van de Werfhorst, H. G. (2016). Vocational education and employment over the life cycle. Sociological Science, 3, 473-494.

Ge, Y. (2006). The effect of foreign direct investment on the urban wage in China: an empirical examination. Urban Studies, 43(9), 1439-1450.

Getis, A. (2009). Spatial weights matrices. Geographical Analysis, 41(4), 404-410.

Goldsmith-Pinkham, P., Sorkin, I., \& Swift, H. (2018). Bartik instruments: What, when, why, and how (0898-2937). Retrieved from

Gorg, H., \& Greenaway, D. (2004). Much ado about nothing? Do domestic firms really benefit from foreign direct investment? The World Bank Research Observer, 19(2), 171-197.

Guimaraes, P., Figueiredo, O., \& Woodward, D. (2000). Agglomeration and the location of foreign direct investment in Portugal. Journal of Urban Economics, 47(1), 115-135.

Hale, G., \& Xu, M. (2016). FDI effects on the labor market of host countries. 
Hanson, G. H. (2007). Globalization, labor income, and poverty in Mexico. In Globalization and poverty (pp. 417-456): University of Chicago Press.

Hanushek, E. A., Schwerdt, G., Woessmann, L., \& Zhang, L. (2017). General education, vocational education, and labor-market outcomes over the lifecycle. Journal of human resources, 52(1), 48-87.

Harrison, A., McLaren, J., \& McMillan, M. (2011). Recent perspectives on trade and inequality: The World Bank.

Heathcote, J., Perri, F., \& Violante, G. L. (2010). Unequal we stand: An empirical analysis of economic inequality in the United States, 1967-2006. Review of Economic dynamics, 13(1), 15-51.

Heckman, J. J., Lochner, L. J., \& Todd, P. E. (2003). Fifty years of Mincer earnings regressions (0898-2937). Retrieved from

Herzer, D., \& Nunnenkamp, P. (2011). FDI and income inequality: Evidence from Europe. Retrieved from

Hong, E., \& Sun, L. (2011). Foreign direct investment and total factor productivity in China: A spatial dynamic panel analysis. Oxford Bulletin of Economics and Statistics, 73(6), 771791.

ILO. (2014). World of Work Report 2014: Developing with jobs: International Labour Office.

Im, H., \& McLaren, J. (2015). Does foreign direct investment raise income inequality in developing countries? A new instrumental variables approach. School of Economics and Finance, Yeungnam University.

Inoue, A., \& Solon, G. (2006). A portmanteau test for serially correlated errors in fixed effects models. Econometric Theory, 22(5), 835-851.

Islam, N. (2003). What have we learnt from the convergence debate? Journal of Economic Surveys, 17(3), 309-362.

Jaumotte, F., Lall, S., \& Papageorgiou, C. (2013). Rising income inequality: technology, or trade and financial globalization? IMF Economic Review, 61(2), 271-309.

Javorcik, B. S. (2014). Does FDI Bring Good Jobs to Host Countries? World Bank Policy Research Working Paper(6936).

Justino, P., Litchfield, J., \& Pham, H. T. (2008). Poverty dynamics during trade reform: evidence from rural Vietnam. Review of Income and Wealth, 54(2), 166-192. 
Kelejian, H., \& Piras, G. (2017). Spatial econometrics: Academic Press.

Kneller, R., \& Pisu, M. (2007). Industrial linkages and export spillovers from FDI. World Economy, 30(1), 105-134.

Kohpaiboon, A. (2006). Foreign direct investment and technology spillover: A cross-industry analysis of Thai manufacturing. World Development, 34(3), 541-556.

Kovak, B. K. (2013). Regional effects of trade reform: What is the correct measure of liberalization? American Economic Review, 103(5), 1960-1976.

Krugman, P. (1991). Increasing returns and economic geography. Journal of Political Economy, 99(3), 483-499.

Kuznets, S. (1955). Economic growth and income inequality. The American Economic Review, $45(1), 1-28$.

Lall, S. (1978). The pattern of intra-firm exports by US multinationals. Oxford Bulletin of Economics and Statistics, 40(3), 209-222.

LaLonde, R. J. (1986). Evaluating the econometric evaluations of training programs with experimental data. The American Economic Review, 604-620.

LeSage, J. (2014). What Regional Scientists Need to Know about Spatial Econometrics. The Review of Regional Studies, 44(1), 13-32.

LeSage, J. P., \& Pace, R. K. (2011). Pitfalls in higher order model extensions of basic spatial regression methodology. The Review of Regional Studies, 41(1), 13.

Lin, S. C., Kim, D. H., \& Wu, Y. C. (2013). Foreign direct investment and income inequality: Human capital matters. Journal of Regional Science, 53(5), 874-896.

Lipsey, R. E. (2004). Home-and host-country effects of foreign direct investment. In Challenges to globalization: Analyzing the economics (pp. 333-382): University of Chicago Press.

Lipsey, R. E., \& Sjöholm, F. (2004). Foreign direct investment, education and wages in Indonesian manufacturing. Journal of Development Economics, 73(1), 415-422.

Looney, A., \& Yannelis, C. (2015). A crisis in student loans?: How changes in the characteristics of borrowers and in the institutions they attended contributed to rising loan defaults. Brookings Papers on Economic Activity, 2015(2), 1-89.

Lu, Y., Tao, Z., \& Zhu, L. (2017). Identifying FDI spillovers. Journal of International Economics, $107,75-90$. 
Malamud, O., \& Pop-Eleches, C. (2010). General education versus vocational training: Evidence from an economy in transition. The review of economics and statistics, 92(1), 43-60.

Mallick, R., \& Carayannis, E. G. (1994). Regional economic convergence in Mexico: An analysis by industry. Growth and Change, 25(3), 325-334.

Mankiw, N. G., Romer, D., \& Weil, D. N. (1992). A contribution to the empirics of economic growth. The Quarterly Journal of Economics, 107(2), 407-437.

Matsuyama, K. (2007). Beyond icebergs: Towards a theory of biased globalization. The Review of Economic Studies, 74(1), 237-253.

McCaig, B. (2011). Exporting out of poverty: Provincial poverty in Vietnam and US market access. Journal of International Economics, 85(1), 102-113.

McCaig, B., \& Pavcnik, N. (2013). Moving out of agriculture: structural change in Vietnam (08982937). Retrieved from

McLaren, J., \& Yoo, M. (2017). FDI and inequality in Vietnam: An approach with census data. Journal of Asian Economics, 48, 134-147.

Meer, J. (2007). Evidence on the returns to secondary vocational education. Economics of Education Review, 26(5), 559-573.

Meyer, B. D., \& Sullivan, J. X. (2017). Consumption and Income Inequality in the US Since the 1960s (0898-2937). Retrieved from

Mincer, J. (1958). Investment in human capital and personal income distribution. Journal of Political Economy, 66(4), 281-302.

Mirza, H., \& Giroud, A. (2003). The Impact of Foreign Direct Investment on the Economic Development of ASEAN Economies: A Preliminary Analysis: Bradford University School of Management.

Moenjak, T., \& Worswick, C. (2003). Vocational education in Thailand: a study of choice and returns. Economics of Education Review, 22(1), 99-107.

Newhouse, D., \& Suryadarma, D. (2011). The value of vocational education: High school type and labor market outcomes in Indonesia. The World Bank Economic Review, 25(2), 296322.

Nguyen, A. N., \& Nguyen, T. (2008). Foreign direct investment in Vietnam: Is there any evidence of technological spillover effects. 
Nguyen, P. A., Phan, T. H., \& Simioni, M. (2016). Productivity Convergence in Vietnamese Manufacturing Industry: Evidence Using a Spatial Durbin Model. In Causal Inference in Econometrics (pp. 603-619): Springer.

Piketty, T. (2014). Capital in the twenty-first century. Cambridge Massachusetts: The Belknap Press of Harvard University Press.

Piras, G., \& Arbia, G. (2007). Convergence in per-capita GDP across EU-NUTS2 regions using panel data models extended to spatial. Statistica, 67(2), 157-172.

Plumper, T., \& Neumayer, E. (2010). Model specification in the analysis of spatial dependence. European Journal of Political Research, 49(3), 418-442.

Quah, D. (1993). Galton's fallacy and tests of the convergence hypothesis. The Scandinavian Journal of Economics, 427-443.

Raveh, O., \& Reshef, A. (2016). Capital imports composition, complementarities, and the skill premium in developing countries. Journal of Development Economics, 118, 183-206.

Rey, S. J., \& Montouri, B. D. (1999). US regional income convergence: a spatial econometric perspective. Regional Studies, 33(2), 143-156.

Rodrik, D. (2011). The future of economic convergence (0898-2937). Retrieved from

Rodrik, D. (2016). Premature deindustrialization. Journal of Economic Growth, 21(1), 1-33.

Roodman, D. (2006). How to do xtabond2: An introduction to difference and system GMM in Stata.

Seshan, G. K. (2005). The Impact of Trade Liberalization on Household Welfare in Vietnam. World Bank Policy Research Working Paper (3541).

SkillsFuture (2017). 2016 Year in Review. http://www.skillsfuture.sg/NewsAndUpdates/DetailPage/df150d4a-411c-476b-897177abe4be84d1

Solow, R. M. (1956). A contribution to the theory of economic growth. The Quarterly Journal of Economics, 70(1), 65-94.

Statistics UNESCO. http://uis.unesco.org/.

Tan, D., \& Meyer, K. E. (2011). Country-of-origin and industry FDI agglomeration of foreign investors in an emerging economy. Journal of International Business Studies, 42(4), 504520. 
Taylor, K., \& Driffield, N. (2005). Wage inequality and the role of multinationals: Evidence from UK panel data. Labour Economics, 12(2), 223-249.

The Conference Board. (2017). International Labor Comparisons Program.

Tien, M. V., Thu, P. X., Viet, N. Q., \& Huyen, D. T. (2015). Vocational training report, Viet Nam, 2013-2014.

Tobler, W. R. (1969). Geographical filters and their inverses. Geographical Analysis, 1(3), 234253.

Topalova, P. (2007). Trade liberalization, poverty and inequality: Evidence from Indian districts. In Globalization and poverty (pp. 291-336): University of Chicago Press.

Topalova, P. (2010). Factor immobility and regional impacts of trade liberalization: Evidence on poverty from India. American Economic Journal: Applied Economics, 2(4), 1-41.

UNCTAD. (1999). World Investment Report 1999: foreign direct investment and the challenge of development. In: United Nations Geneva.

UNESCO-UNEVOC. http://www.unevoc.unesco.org/go.php?q=World+TVET+Database.

Venables, A. J. (2005). Spatial disparities in developing countries: cities, regions, and international trade. Journal of Economic Geography, 5(1), 3-21.

Vohra, R. (1996). How fast do we grow? Growth and Change, 27(1), 47-54.

Wang, J.-Y., \& Blomström, M. (1992). Foreign investment and technology transfer: A simple model. European economic review, 36(1), 137-155.

Wei, Y. D. (1999). Regional inequality in China. Progress in Human Geography, 23(1), 49-59.

Wu, J.-Y., \& Hsu, C.-C. (2012). Foreign direct investment and income inequality: Does the relationship vary with absorptive capacity? Economic Modelling, 29(6), 2183-2189.

Yang, J. (1998). General or vocational? The tough choice in the Chinese education policy. International Journal of Educational Development, 18(4), 289-304.

Zhu, S. C., \& Trefler, D. (2005). Trade and inequality in developing countries: a general equilibrium analysis. Journal of International Economics, 65(1), 21-48. 